\author{
UNIVERSIDADE DE SÃO PAULO \\ Faculdade De Ciências Farmacêuticas \\ Programa de Pós-Graduação em Farmácia \\ Área de Análises Clínicas
}

\title{
Vacinologia de Sistemas Aplicada à Vacina rVSV-ZEBOV contra Ebola
}

\author{
Patrícia Conceição Gonzalez Dias Carvalho \\ Tese apresentada para obtenção do título de Doutor em Ciências \\ Orientador: Professor Doutor Helder Takashi Imoto Nakaya
}

\section{São Paulo}




\author{
UNIVERSIDADE DE SÃO PAULO \\ Faculdade De Ciências Farmacêuticas \\ Programa de Pós-Graduação em Farmácia \\ Área de Análises Clínicas
}

\title{
Vacinologia de Sistemas Aplicada à Vacina rVSV-ZEBOV contra Ebola
}

\author{
Patrícia Conceição Gonzalez Dias Carvalho \\ Versão corrigida da Tese conforme resolução CoPGr 6018. \\ Tese para obtenção do Título de Doutor \\ Orientador: Professor Doutor Helder Takashi Imoto Nakaya
}

\section{São Paulo}


Autorizo a reprodução e divulgação total ou parcial deste trabalho, por qualquer meio convencional ou eletronico, para fins de estudo e pesquisa, desde que citada a fonte.

Ficha Catalográfica elaborada eletronicamente pelo autor, utilizando o programa desenvolvido pela Seção Técnica de Informática do ICMC/USP e adaptado para a Divisăo de Biblioteca e Documentação do Conjunto das Químicas da USP

Bibliotecária responsável pela orientação de catalogação da publicação: Marlene Aparecida Vieira - CRB - 8/5562

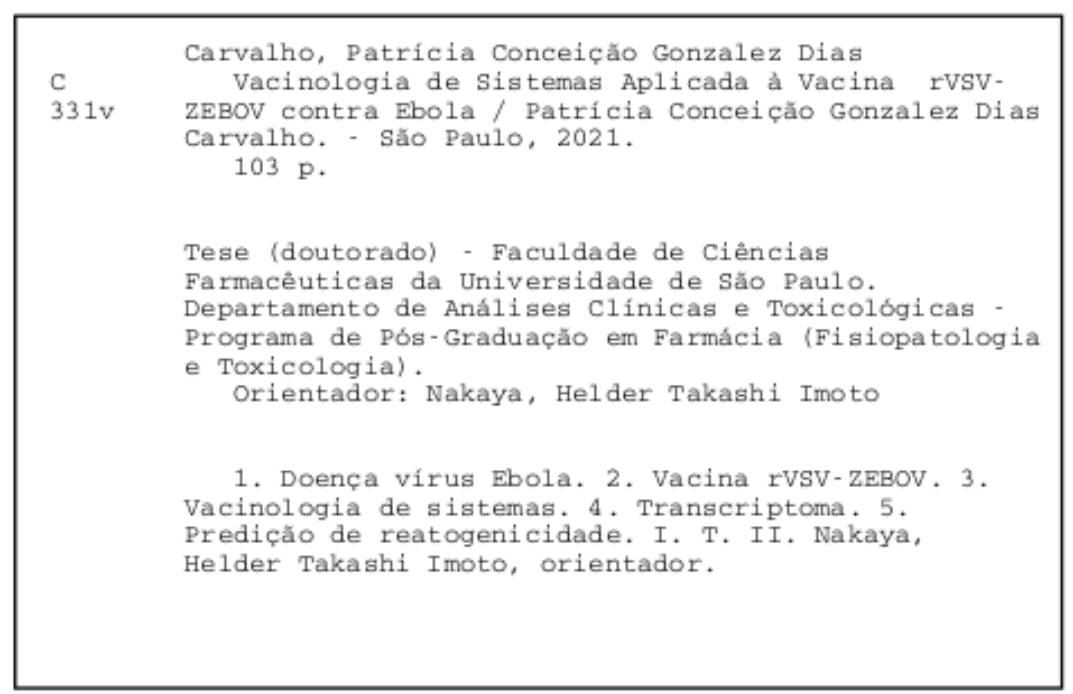


Patrícia Conceição Gonzalez Dias Carvalho

\section{Vacinologia de Sistemas Aplicada à Vacina rVSV-ZEBOV contra Ebola}

Comissão Julgadora da Tese para obtenção do Título de Doutor em Ciências

Prof. Dr. Helder Takashi Imoto Nakaya

Orientador/Presidente

Helder Takashi Imoto Nakaya

$1^{\circ}$ examinador:

Ronaldo Fumio Hashimoto

$2^{\circ}$ examinador

$\underline{\text { Irene da Silva Soares }}$

$3^{\circ}$ examinador:

Daniela Mulari Ferreira

$4^{\circ}$ examinador:

São Paulo, 11 de março de 2021 


\section{Dedicação}

Dedico este trabalho a Deus.

"Quem Ihe deu primeiro, para que Ihe seja retribuído? D’Ele, por Ele e para Ele são todas as coisas. A Ele a glória por toda a eternidade! Amém."

Romanos 11, 35-36 


\section{Agradecimentos}

Meu muitíssimo obrigado ao meu orientador Dr. Helder Imoto Nakaya. Agradeço por ter aceitado o desafio de orientar uma imunologista sem nenhum conhecimento prévio em programação. Por ter prezado pelo andamento do meu trabalho, deixando toda a infraestrutura para que eu conseguisse trabalhar da melhor maneira possível. E principalmente, por ter compartilhado comigo tanto de sua experiência e de sua paixão por ciência.

Ainda no âmbito acadêmico, devo agradecer a Thiago Dominguez Crespo Hirata que em vários momentos me orientou e sempre se dispôs a me ajudar. Agradeço imensamente a toda a equipe do CSBL: Pedro Russo, Diógenes, Jaque, Lucas Cardozo, Matheus Bürguer, César, Mindy, Melissa, Fernando, Gustavo, Fábio, Sara, Mari, Nath, Vivi, André Nicolau, Diogo, André Guilherme, Allyson, Deney, Bruna, Isabelle, Tiago, Jefferson Leandro, Rodrigo, Ícaro, Amanda, Juan, Jeevan, Vanessa, Felipe Ten Caten, Felipe Martins. Juliana, Lucas Kaoro, Maiara, Matheus, Mauro, Luana, Lucas Barbosa, Leandro Mano. Agradeço a cada um de vocês por todos os momentos compartilhados e pela grande troca de experiências.

Agradeço a Universidade de São Paulo, Faculdade de Ciências Farmacêuticas, e o Departamento de Análises Clínicas e Toxicológicas por garantirem todo o suporte para o desenvolvimento da minha tese de doutorado. Agradeço ao Programa de Pós-Graduação Farmácia (Fisiopatologia e Toxicologia) da FCF e a todos os pesquisadores e professores da USP que lutam por uma educação digna, ensino de qualidade e principalmente por uma ciência de alto nível.

Agradeço a CAPES pelo apoio financeiro sem o qual não conseguiria me dedicar a este trabalho: $O$ presente trabalho foi realizado com apoio da Coordenação de Aperfeiçoamento de Pessoal de Nível Superior - Brasil (CAPES) - Código de Financiamento 001.

Agradeço aos membros da banca examinadora, por terem aceitado o convite, pela atenção dispensada e pelas contribuições para a finalização deste trabalho. Agradeço à Coordenação do Curso de Pós-Graduação e à Elaine, Edna e Samantha pela paciência e pela imensa ajuda na parte burocrática do processo.

Não poderia deixar de agradecer também aos voluntários do meu estudo e a todos os pesquisadores envolvidos no VSV-EBOVAC e VSV-EBOPLUS que tornaram esse trabalho possível.

Agradeço a todos os meus professores desde a infância até a Pós-graduação, que me ensinaram, me inspiraram e me instigaram a buscar cada vez mais conhecimento. Agradeço às instituições onde estudei, entre elas Grupo escolar Avamor Berlanga Mugnai, Escola Manuel Teixeira Júnior, Colégio Objetivo de 
Pacaembu, Universidade Federal da Grande Dourados, Instituto Oswaldo Cruz e Universidade de São Paulo.

Agradeço ao meu marido e grande amigo Felipe Cavassana de Carvalho por não medir esforços para me apoiar nesta empreitada, com ele divido a vida e este trabalho. Agradeço aos meus amados pais, Miguel Dias Garcia e Luiza Gonzalez Dias, que dedicaram todos os seus esforços (que não foram poucos) para garantir para mim e para meus irmãos a melhor educação possível. Agradeço também aos meus queridos irmãos Marcelo e Fabrício que sempre me apoiaram, incentivaram e aconselharam.

Aos meus amigos e familiares que entenderam (às vezes nem tanto) a minha ausência em muitas (quase todas) datas comemorativas. Pessoas que mesmo de longe se orgulhavam e comemoraram comigo as minhas conquistas. E a todos aqueles que, direta ou indiretamente, contribuíram para a realização deste trabalho. Divido com todos vocês mais uma etapa de minha vida.

Por fim, agradeço a Deus, pois todo este trabalho foi feito por amor a Ele e à Ciência! A Ele devo características que estão inseridas em minha alma: persistência e determinação, sem as quais a conclusão deste trabalho não seria possível. 
Carvalho, P. C. G. D. Vacinologia de Sistemas Aplicada à Vacina rVSV-ZEBOV contra Ebola. 2021..Tese (Doutorado) - Faculdade de Ciências Farmacêuticas, Universidade de São Paulo, São Paulo, 2021.

\section{Resumo}

A febre hemorrágica causada pelo vírus Ebola é uma doença grave com alta mortalidade, sendo a vacinação uma importante estratégia de intervenção. A rVSV-ZEBOV, uma vacina recombinante do vírus da estomatite vesicular (VSV) em que a glicoproteína de envelope é a do vírus Ebola da cepa Zaire, foi a primeira aprovada para uso clínico. Apesar de imunogênica e segura, a vacina é reatogênica podendo causar febre, calafrios, mialgia e artrite. Usando dados de transcriptoma do sangue nós realizamos análises de transcriptoma para compreender a resposta à vacina em diferentes tempos para 4 diferentes coortes. A partir dos mesmos dados obtidos antes da vacinação, nós identificamos conjuntos de genes preditores de eventos adversos relacionados à vacina rVSV-ZEBOV. Os dados foram obtidos por RNA-seq para 64 voluntários e por dual-color Reverse Transcriptase Multiplex Ligation-dependent Probe Amplification (dcRT-MLPA) para 375 voluntários entre vacinados e placebos. A identificação de genes preditores das reações adversas foi realizada utilizando o algoritmo Random Forest. Com o algoritmo "AdaBoost" obtivemos modelo capaz de predizer indivíduos com artrite, com valor preditivo positivo de 1 e valor preditivo negativo de 0.818 , utilizando dados de expressão de apenas cinco genes. Este trabalho foi importante para compreender melhor a resposta induzida pela vacina rVSV-ZEBOV e identificar genes possivelmente relacionados à predisposição das pessoas a desenvolver reatogenicidade pós vacinal.

Palavras-chave: Ebola, vacina, vacina rVSV-ZEBOV, aprendizado de máquina, eventos adversos 
Carvalho, P. C. G. D. Systems Vaccinology of rVSV-ZEBOV Ebola Vaccine. 2021..Tese (Doutorado) - Faculdade de Ciências Farmacêuticas, Universidade de São Paulo, São Paulo, 2021.

\begin{abstract}
Hemorrhagic fever caused by the Ebola virus is a high mortality disease, and vaccination is an important intervention strategy. The rVSV-ZEBOV, a recombinant vesicular stomatitis virus (VSV) vaccine in which the envelope glycoprotein is that of the Ebola virus of the Zaire strain, was the first one to be approved for medical use. Although immunogenic and safe, the vaccine is very reactogenic and can cause fever, chills, myalgia and arthritis. From blood transcriptome data we performed transcriptome analysis to understand the response to the vaccine at different time points for 4 different cohorts. With the same data obtained before vaccination, we identified sets of genes that predict adverse events related to the rVSV-ZEBOV vaccine. Data were obtained by RNA-seq for 64 volunteers and by dual-color Reverse Transcriptase Multiplex Ligation-dependent Probe Amplification (dcRT-MLPA) for 375 volunteers. The identification of predictor genes was performed with Random Forest Algorithm. Using the "AdaBoost" algorithm, we selected a model capable of predicting individuals with arthritis, with positive predictive value of 1 , and negative predictive value of 0.818 based on expression data from only five genes. This work was important to better understand the response induced by the rVSV-ZEBOV vaccine and to identify genes possibly related to people's predisposition to develop post-vaccine reactogenicity.
\end{abstract}

Keywords: Ebola, vaccine, rVSV-ZEBOV vaccine, Machine Learning, adverse events 


\section{Lista de Abreviaturas e Siglas}

Ad26.ZEBOV: adenovirus type 26 vector-based vaccine

Ad5-EBOV: Human adenovirus 5 vectored 2014 glycoprotein insert

Ada: Boosted Classification Trees

ANN: Artificial Neural Network

AUC: Area Under the Curve

cAd3-EBO Z: Chimp adenovirus 3 vectored glycoprotein

CDKN1A: Cyclin Dependent Kinase Inhibitor $1 \mathrm{~A}$

CEMiTool: Co-expression Modules identification Tool

CT: Cycle Threshold

CX3CL1: C-X3-C Motif Chemokine Ligand 1

dcRT-MLPA: dual-color Reverse Transcriptase Multiplex Ligation-dependent Probe Amplification

DEG: Differentially Expressed Genes

DNA: Ácido desoxirribonucleico

EBOV: Ebola Virus

ELISA: Enzyme-Linked Immunosorbent Assay

EVD: Ebola Virus Disease

FBXO6: F-Box Protein 6

GNLY (do inglês, Granulysin) (Artralgia, Náusea, Evento Adverso Local )

GSEA: Gene Set Enrichment Analysis

GWAS: Gene Wide Association Analysis

HSPA1A: Heat Shock $70 \mathrm{KDa}$ Protein 1A),

HSPA1B: Heat Shock $70 \mathrm{KDa}$ Protein 1B)

IFI44: Interferon Alpha Inducible Protein 44),

IFI44L: Interferon Induced Protein 44 Like 
IFI44L: Interferon Induced Protein 44 Like

IFI6: Interferon Alpha Inducible Protein 6

IFIT2: Interferon Induced Protein With Tetratricopeptide Repeats 2

IFIT3: Interferon Induced Protein With Tetratricopeptide Repeats 3

IFITM3: Interferon Induced Transmembrane Protein 3

IFN: Interferon

IFN-g: Interferon Gamma

IgG: Imunoglobulina G

IgM: Imunoglobulina M

IL-18: Interleukin 18

IL-1及: Interleukin $1 \beta$

IRF7: Interferon regulatory factor 7

ISG: Interferon-Stimulated Genes

KBTBD3: Kelch Repeat And BTB Domain Containing 3).

KNN: K-nearest Neighbor

LYN: Tyrosine-Protein Kinase Lyn

MACF1: Microtubule-actin cross-linking factor 1

MDGI: Mean Decrease Gini Index

MOV10: Mov10 RISC Complex RNA Helicase

MRPL11: 39S ribosomal protein L11

MVA-BN-Filo: modified vaccinia Ankara (MVA) vector-based vaccine

NES: Normalized Enrichment Score

NLRP1: NLR Family Pyrin Domain Containing 1

OAS2: 2'-5'-oligoadenylate synthetase 2

OAS3: 2'-5'-Oligoadenylate Synthetase 3

ORA: Over-representation Analysis 
pb: pares de bases

PBMC: Peripheral blood mononuclear cell

PCR: Polymerase chain reaction

PPI: Protein-protein interaction

PRF1: Perforin 1

PRR: Pattern recognition receptor

PVCA: Principal Variance Component Analysis

qRT-PCR: Reverse transcription - quantitative real-time polymerase chain reaction

RAB13: RAB13 Member RAS Oncogene Family

RDC: República Democrática do Congo

RFE: Recursive Feature Elimination

RNA: Ácido Ribonucléico

RNA-seq: Sequenciamento de RNA empregado para o estudo do transcriptoma

ROC: Receiver Operating Characteristics

SLC25A2: Mitochondrial Ornithine Transporter 2

SVM: Support Vector Machine

T CAR: Chimeric antigen receptor T cells

TLR: Toll-like receptor

TMM: Trimmed Mean of M-Value

TNFRSF1A: TNF Receptor Superfamily Member 1A

TRAF6: TNF receptor-associated factor

USA: United States of America

VCL: Vinculin

VST: Variance Stabilizing Transformation

WGCNA: Weighted Gene Coexpression Network Analysis

XIAP: X-linked inhibitor of apoptosis protein 


\section{Lista de Tabelas}

Tabela 1. Dados de expressão gênica disponíveis por coorte .31

Tabela 2. Scores obtidos com o modelo de predição de artrite. .76

Tabela Suplementar 1. Número absoluto de eventos adversos por coorte... 97

Tabela Suplementar 2. Número relativo de eventos adversos por coorte. .97 


\section{Lista de Figuras}

Figura 1. Reatogenicidade induzida pela vacina VSV-ZEBOV em diferentes coortes .24

Figura 2. Fluxograma para a definição e avaliação de modelos preditivos 40

Figura 3. Análise de componente principal das amostras de voluntários .44

Figura 4. PVCA dos dados de RNA-seq obtidos com a coorte de Genebra.

Figura 5. Número de genes diferencialmente expressos por tempo de coleta após a vacinação com VSV-ZEBOV 46

Figura 6.Análise de sobre representação de vias enriquecidas de DEGs encontrados 1 dia após a imunização dos voluntários. 48

Figura 7. Resultado da análise de sobre representação de vias enriquecidas em voluntários 7 dias após a imunização.

Figura 8. Análise de enriquecimento da comparação de voluntários no dia 1 pós-vacinação com rVSV-ZEBOV em relação aos voluntários antes da vacinação (dia 0) .50

Figura 9. Rede de interação proteína-proteína construída com os DEGs do dia 1. .52

Figura 10. Análise de coexpressão de voluntários imunizados com a vacina rVSV-ZEBOV e voluntários placebos. .54

Figura 11. PVCA dados de dcRT-MLPA das coortes de Genebra, Kilifi, Gabão e EUA .55

Figura 12. Impacto das coortes nos perfis de expressão gênica antes da vacinação com rVSV-ZEBOV para os dados antes e depois da remoção do efeito de lote....56

Figura 13. Número de Genes Diferencialmente expressos por coorte e tempo de comparação obtidos a partir de dados de dcRT-MLPA. .57

Figura 14. Número de DEGs compartilhados entre as quatro coortes no dia 7 após a vacinação .58

Figura 15. Análise de enriquecimento a partir dos 8 DEGs compartilhados entre todas as coortes no dia 7 .59 
Figura 16. Análise de coexpressão com dados de dcRT-MLPA da coorte de Genebra 60

Figura 17 Análise de coexpressão com dados de dcRT-MLPA da coorte de Kilifi 61

Figura 18. Análise de coexpressão com dados de dcRT-MLPA da coorte de Gabão. 63

Figura 19. Análise de coexpressão com dados de dcRT-MLPA da coorte dos EUA .64

Figura 20. Número de vacinados com presença ou ausência de eventos adversos

Figura 21. Genes ranqueados entre os $10 \mathrm{com}$ maior valor de importância na classificação de voluntários com eventos adversos à vacinação obtidos com o algoritmo Random Forest.

Figura 22. Rede de conexão de eventos adversos e genes melhor ranqueados para pelo menos 3 eventos adversos. 68

Figura 23. Dispersão de amostras de voluntários no tempo inicial quanto a incidência ou não de artrite na coorte de Genebra ..... .70

Figura 24. Dispersão de amostras de voluntários no tempo inicial quanto a incidência ou não de artrite na coorte de Genebra a partir dos 5 genes selecionados para os dados de treino e de teste..... 72

Figura 25. Expressão dos genes selecionados como preditores de artrite em amostras de voluntários em diferentes tempos. .... .73

Figura 26. Expressão dos genes selecionados como preditores de artrite em amostras de voluntários com ou sem artrite no tempo inicial 74

Figura 27. Curvas ROC dos dados de treino e de teste na predição de artrite utilizando o algoritmo Adaboost .75 


\section{Sumário}

$\begin{array}{ll}\text { 1. Introdução } & 17\end{array}$

1.1. Epidemiologia da doença por vírus Ebola 17

1.2. Vírus Ebola 18

1.3. Doença do Vírus Ebola 18

1.4. Vacinas contra Ebola em uso 20

1.5. Vacina rVSV-ZEBOV 22

1.6. Eventos adversos à vacinação 25

1.7. Vacinologia de Sistemas 26

1.8. Aprendizado de Máquina $\quad 27$

2. Objetivos 29

2.1. Objetivo principal 29

2.2. Objetivos específicos 29

3. Materiais e métodos 30

3.1. Programas computacionais $\quad 30$

3.2. Dados Disponíveis do VSV-EBOPLUS 30

3.3. Dados de RNA-seq 31

3.3.1. Preparação de biblioteca de transcriptoma e sequenciamento 32

3.3.2. Pré-processamento de dados de RNA-seq 32

3.3.3. Avaliação da variabilidade dos dados 33

3.3.4. Análise de expressão diferencial 33

3.3.5. Análise de Enriquecimento de vias 34

3.3.6. Análise de Redes de interação proteína-proteína 35

3.3.7. Análise de Redes de Coexpressão 35

3.4.1. Pré processamento de dados de dcRT-MLPA 38

3.4.2. Avaliação da variabilidade dos dados 38

3.4.3. Análise de expressão diferencial 38

3.4.4. Enriquecimento de vias 39 
3.4.5. Análise de Redes de Coexpressão

3.5 Integração de dados de expressão gênica e reatogenicidade 39

3.5.1. Pré-processamento dos dados 41

3.5.2. Seleção de atributos 42

3.5.3. Definição de Modelos preditivos 43

4. Resultados 44

4.1. Dados de RNA-seq 44

4.1.1. Avaliação da variabilidade dos dados 44

4.1.2 Análise de expressão diferencial 46

4.1.3. Análise de Enriquecimento funcional (Sobre representação) $\quad 47$

4.1.4. Análise de Enriquecimento de Gene sets (GSEA) 50

4.1.5. Análise de rede de interação proteína-proteína 51

4.1.6. Análise de redes de Coexpressão 53

4.2 Dados de dcRT-MLPA 55

4.2.1. Pré processamento de dados de dcRT-MLPA 55

4.2.2. Avaliação da variabilidade dos dados

4.2.3. Análise de expressão diferencial 57

4.2.4. Análise de Redes de Coexpressão 59

4.3 Integração de dados de expressão gênica e reatogenicidade 65

4.3.1. Seleção de atributos 66

4.3.2. Definição de Modelo preditivo de Artrite 69

5. Discussão 76

6. Conclusão $\quad 85$

7. Referências Bibliográficas $\quad 86$

$\begin{array}{ll}\text { 8. Anexos } & 97\end{array}$ 


\section{Introdução}

\subsection{Epidemiologia da doença por vírus Ebola}

O vírus Ebola (ZEBOV; EBOV) é um membro da família Filoviridae, gênero Ebolavirus, da espécie Zaire Ebolavirus. Este é responsável por uma febre hemorrágica viral devastadora conhecida como Doença do Vírus Ebola (EVD, do inglês Ebola Virus Disease) e é a mais letal entre os vírus Ebola patogênicos para humanos, com taxa de letalidade de até 90\% (JADAV et al., 2015).

Desde a primeira descrição do vírus Ebola em 1976, mais de 24 epidemias desta doença foram relatadas na África (Baştuğ \& Bodur, 2015). Em 21 de março de 2014 foi relatado pela Organização Mundial de Saúde (OMS) o maior surto já registrado, acometendo mais de 27.000 pessoas, com mais de 11.000 óbitos na África Ocidental (WHO, 2015). Pouco tempo depois, em 8 de maio de 2018, a República Democrática do Congo (RDC) declarou um surto de EVD com uma estimativa de 1.400 casos e 957 mortes (OMS, 2019). No momento, um novo surto acontece na Guiné. O surto foi declarado em 14 de fevereiro de 2021, com o primeiro caso diagnosticado no dia 18 de janeiro, pouco menos de um mês antes (OMS, 2021).

A EVD é considerada endêmica na África (MALVY et al., 2019), tendo animais como reservatórios do vírus, tais como morcegos frugívoros, gorilas, chimpanzés, antílopes e porcos-espinhos. Sendo assim, enquanto humanos tiverem contato com esses animais em seus habitats, haverá chance do de acontecer uma nova epidemia (EMANUEL; MARZI; FELDMANN, 2018). Devido à alta letalidade, a transmissão entre humanos causa grande preocupação às autoridades de saúde de todo o mundo (MURRAY, 2015). Esta endemicidade causa especial preocupação devido à alta letalidade da doença e pela transmissão entre humanos, mobilizando autoridades de saúde de todo o mundo sempre que cidades maiores são acometidas por um surto de Ebola no continente africano. Esta mobilização ocorre dada a probabilidade do vírus ser transmitido acidentalmente para outras regiões por um viajante (MURRAY, 2015). 


\subsection{Vírus Ebola}

A família dos filovírus inclui alguns dos vírus mais letais conhecidos, por exemplo, o vírus Ebola e o vírus Marburg (AMMAN et al., 2017). Esses vírus são altamente contagiosos, com surtos periódicos, tornando os filovírus importantes ameaças à saúde pública (EDWARDS; BASLER, 2019).

O gênero Ebolavirus inclui cinco espécies: Bundibugyo Ebolavirus, Reston Ebolavirus, Sudan Ebolavirus, Tai Forest Ebolavirus e Zaire Ebolavirus (BUKREYEV et al., 2014; MALVY et al., 2019). Entre eles, o Ebolavirus do Zaire, geralmente chamado vírus Ebola (EBOV), é o principal agente causador de surtos humanos, causando a EVD (HOENEN et al., 2006; WORLD HEALTH ORGANIZATION, 1978).

O genoma dos filovírus tem aproximadamente 19 quilobases de comprimento e codifica até nove produtos de tradução, de sete unidades de transcrição separadas (BHARAT et al., 2012; MARTIN; CANARD; DECROLY, 2017). Esses genes codificam a nucleoproteína viral (NP), as proteínas virais de 24, 30, 35 e 40 kDa (VP24, VP30, VP35 e VP40, respectivamente), uma glicoproteína transmembrana tipo I (GP), e a polimerase viral (L) (BECKER et al., 1998; HUANG et al., 2002).

Membros do gênero Ebolavirus também produzem formas secretadas da proteína GP. Esta é a única proteína de superfície do vírus com pontas triméricas que facilitam a invasão por ligação ao receptor e fusão com as células alvo (MEHEDI et al., 2011). Por estar associada à indução de resposta imune protetora (LAl et al., 2017), a glicoproteína GP é o principal antígeno usado em todas as vacinas candidatas contra Ebola (BLANEY et al., 2013; BUKREYEV et al., 2007; SULLIVAN et al., 2000, 2006; WARFIELD et al., 2007).

\subsection{Doença do Vírus Ebola}

A doença do vírus Ebola é um transtorno altamente complexo, com sintomas graves e distúrbios multissistêmicos que incluem inflamação, lesão de múltiplos órgãos e choque hemorrágico (MALVY et al., 2019; MURRAY, 2015). Um desafio no controle da doença é que além de ser altamente letal é facilmente transmitida pelo 
contato entre pessoas, por fluidos corporais (sangue, suor, excrementos, etc.). 0 vírus tem um período de incubação que varia de 1 a 21 dias. Os sinais e sintomas iniciais da doença são inespecíficos, como febre, fadiga, dor muscular, dor de cabeça e dor na garganta, seguido de dor de barriga, náusea, vômito e diarréia, que são facilmente confundidos com outras doenças comuns (LELIGDOWICZ et al., 2016). Devido a essa semelhança, a infecção é geralmente ignorada, mas em alguns pacientes acontece uma evolução rápida, para a forma hemorrágica grave, na qual há falência múltipla dos órgãos, choque hipovolêmico, coagulação intravascular, deficiência visual e auditiva e sangramento. Estes sintomas severos podem levar ao óbito, com mortalidade de até 90\% (CHERTOW et al., 2014; LELIGDOWICZ et al., 2016).

Mesmo em casos de pessoas que se recuperam da EVD, há relatos de que o vírus persiste em locais imunologicamente privilegiados (JACOBS et al., 2016; MALVY et al., 2019), como os testículos (DIALLO et al., 2016), o interior do olho (VARKEY et al., 2015) e o sistema nervoso central (JACOBS et al., 2016). Em mulheres infectadas durante a gravidez, o vírus pode persistir na placenta, líquido amniótico e inclusive no feto (CALUWAERTS et al., 2016). Além disso, em mulheres infectadas durante o período de amamentação, o vírus pode ser detectado no leite materno (SISSOKO et al., 2017). Estudos de persistência viral indicam que em uma pequena porcentagem de sobreviventes, alguns fluidos corporais podem apresentar resultado positivo na reação em cadeia da polimerase via transcriptase reversa (RT-PCR) para o vírus Ebola por mais de 9 meses (MALVY et al., 2019).

A experiência com sobreviventes da EVD do surto na África ocidental deixou clara a necessidade de controlar a transmissão da doença durante a recaída ou através da transmissão sexual, já que milhares de sobreviventes tiveram sequelas como artralgia persistente, artrite e problemas na visão (CLARK et al., 2015; QURESHI et al., 2015; TIFFANY et al., 2016). Os efeitos negativos causados pela EVD na saúde mental de sobreviventes, familiares e membros da comunidade também são consideráveis (HOWLETT et al., 2018). Por estas razões, a vacinação torna-se uma importante e urgente estratégia de intervenção para prevenir desfechos graves da doença (KANAPATHIPILLAl et al., 2014). 


\subsection{Vacinas contra Ebola em uso}

Vários candidatos a vacinas foram eficazes para proteger primatas não humanos contra infecção letal. Estes candidatos incluem vacinas baseadas em vetores de adenovírus com replicação deficiente (TAPIA et al., 2020), vetores de estomatite vesicular (VSV) com replicação competente (MONATH et al., 2019), parainfluenza vírus humano tipo 3 (HPIV-3) (BUKREYEV et al., 2010) e preparações de nanopartículas semelhantes a vírus (BAZZILL et al., 2019). Atualmente, apenas duas vacinas estão em uso: rVSV-ZEBOV e Ad26.ZEBOV / MVA-BN-Filo. Estas estão sendo utilizadas em Guiné, sob regime de vacinação em anel, para conter o surto atual (ECDC, 2021).

A rVSV-ZEBOV, vendida sob a marca Ervebo, foi a primeira aprovada em 2019, primeiramente em novembro pela Comissão Europeia e depois em dezembro nos Estados Unidos. A pré-qualificação da OMS ocorreu menos de 48 horas depois, tornando-se o processo de pré-qualificação da vacina mais rápido já conduzido pela OMS até aquele ano (OMS, 2019 ; FDA, 2019). A aprovação da mesma foi apoiada principalmente por um estudo de fase 3 conduzido com 3.537 indivíduos maiores de 18 anos de idade na Guiné durante o surto de 2014-2016 (HENAO-RESTREPO et al., 2017). Neste estudo de vacinação em anel, que compreende a imunização de contatos e contatos de pessoas infectadas, o Ervebo mostrou eficácia estimada de 100\% (IC de 95\% 79,3-100,0, p = 0,033) na prevenção de casos de Ebola, já que nenhum caso de Ebola ocorreu dez dias ou mais após a randomização entre casos de contatos e contatos de contatos imediatamente vacinados, quando comparados ao casos com vacinação retardada em 21 dias (HENAO-RESTREPO et al., 2017).

O segundo regime vacinal aprovado para uso consiste em dois componentes Ad26.ZEBOV e MVA-BN-Filo, vendidos sob as marcas Zabdeno (EMAa, 2020) e Mvabea (EMAb, 2020), respectivamente. Este regime foi aprovado para uso médico na União Europeia em julho de 2020. A primeira dose é baseada na tecnologia AdVac da Crucell Holland BV (que faz parte da Janssen), e a segunda é baseada na MVA- Tecnologia BN da Bavarian Nordic. O Ad26.ZEBOV é derivado do adenovírus humano serótipo 26 (Ad26) deficiente para replicação (Ad26.ZEBOV), expressando o Zaire Ebola glicoproteína de vírus e uma vacina baseada em vetor de vaccinia 
Ankara (MVA) não replicante, recombinante, modificada, que codifica glicoproteínas do vírus Ebola do Zaire, vírus do Sudão e vírus de Marburg e nucleoproteína do vírus Tai Forest (POLLARD et al., 2020).

Os dados preliminares indicaram que o regime de vacina de primeira dose e reforço induziu uma resposta imunológica temporária nos voluntários. O ensaio de Fase II envolveu 612 voluntários adultos em julho de 2015, no Reino Unido e na França. Um segundo ensaio de Fase II, envolvendo 1.200 voluntários, foi iniciado na África no mesmo ano (POLLARD et al., 2020). Em novembro de 2019, Janssen apresentou um Pedido de Autorização de Introdução no Mercado (MAA) à EMA para aprovação de Ad26.ZEBOV e MVA-BN-Filo (EMA, 2019a). Em maio de 2020, o EMA CHMP recomendou a concessão de uma Autorização de Introdução no Mercado para a combinação das vacinas Ad26.ZEBOV (Zabdeno) (EMA, 2020a) e MVA-BN-Filo (Mvabea) (EMA, 2020b).

Zabdeno é administrado primeiro e Mvabea é administrado aproximadamente oito semanas depois como reforço. Esse regime profilático de duas doses, portanto, não é adequado para uma resposta a surto em que a proteção imediata é necessária (EMA, 2019b).

Outras vacinas em fase de desenvolvimento são Chimp adenovirus 3 vectored glycoprotein (cAd3-EBO Z) (LEDGERWOOD; SULLIVAN; GRAHAM, 2015), produzidas pela GSK e NIAID em fase III, a vacina Human adenovirus 5 vectored 2014 glycoprotein insert (Ad5-EBOV) que teve a fase I finalizada (MARTINS et al., 2016), e HPIV-3 vectored glycoprotein desenvolvida pelo Ministério da Saúde da Rússia e com a fase I planejada (LINGEMANN et al., 2017). Além disso, algumas vacinas estão com fase pré-clínica bem avançada como a Rabies vectored glycoprotein produzida pela Thomas Jefferson University \& NIAID (JOHNSON et al., 2016) e a Ebola $\triangle V P 30 \mathrm{H} 2 \mathrm{O} 2$ treated produzida pela University of Wisconsin, que que já completaram a fase de desafio em primatas não-humanos (MARZI et al., 2015), e finalmente a Purified glycoprotein desenvolvida pela Protein Sciences que teve o desafio em primatas não-humanos iniciado (CLARKE et al., 2017). 


\subsection{Vacina rVSV-ZEBOV}

A rVSV-ZEBOV é uma vacina recombinante do vírus vivo e atenuado da estomatite vesicular (VSV), no qual a glicoproteína envelope de VSV foi substituída pela glicoproteína do vírus Ebola cepa Zaire (ZEBOV-GP) (GARBUTT et al., 2004). Embora esta vacina tenha exibido um perfil favorável de segurança e imunogenicidade em experimentos com animais de pequeno e grande porte (GEISBERT et al., 2008; JONES et al., 2007; WONG et al., 2014) seu desenvolvimento clínico estagnou até o surto de EVD de 2014 (DIXON; SCHAFER, 2014; CDC, 2014). Quando em consulta internacional liderada pela OMS, foi considerada uma das duas únicas candidatas à vacina que mostraram $100 \%$ de proteção em primatas não-humanos (PNH) (JONES et al., 2005; KANAPATHIPILLAI et al., 2014; STANLEY et al., 2014).

Durante o pico da epidemia de 2014, a Agência de Saúde Pública do Canadá (PHAC, do inglês Public Health Agency of Canada) doou 800 frascos de rVSV-ZEBOV para a OMS. A organização então criou um consórcio europeu chamado VEBCON ("VSV-Ebola CONsortium") para iniciar rapidamente a fase I (escalonamento de dose) dos ensaios clínicos de dose única de rVSV-ZEBOV na Alemanha, Quênia e Gabão, bem como um ensaio clínico duplo-cego randomizado correspondente à fase I/II $(\mathrm{RCT})$ realizado na cidade de Genebra-Suíça.

No estudo conduzido na Guiné durante o surto de 2014-2016 com adultos foi conduzido um esquema de vacinação em anel, no qual 3.537 contatos, e contatos de contatos, de indivíduos com doença pelo vírus Ebola confirmada em laboratório (EVD) receberam vacinação "imediata" ou "retardada" por 21 dias. Este estudo foi projetado para capturar uma rede social de indivíduos e locais que poderiam incluir residências ou locais de trabalho onde um paciente passou algum tempo enquanto sintomático, ou as famílias de indivíduos que tiveram contato com o paciente durante a doença ou morte dessa pessoa. Em uma comparação de casos de EVD entre 2.108 indivíduos no braço de vacinação "imediata" e 1.429 indivíduos no braço de vacinação "retardada", o Ervebo foi determinado como 100\% eficaz na prevenção de casos de Ebola com início dos sintomas mais de dez dias após a vacinação. Nenhum caso de EVD com início dos sintomas superior a dez dias após 
a vacinação foi observado no grupo de agrupamento "imediato", em comparação com dez casos de EVD no grupo de agrupamento "retardado" de 21 dias (HENAO-RESTREPO et al., 2017).

Em testes clínicos de fase I, II e III, a vacina rVSV-ZEBOV demonstrou ser segura, imunogênica e protetora. Entretanto, demonstrou reatogenicidade, causando em alguns vacinados sintomas como febre, inflamação, artrites e dermatites (AGNANDJI et al., 2015; HENAO-RESTREPO et al., 2015; HUTTNER et al., 2015; REGULES et al., 2015; SUDER et al.; 2018).

A figura 1 mostra a frequência dos eventos adversos induzidos pela imunização com a vacina rVSV-ZEBOV, nas coortes de Genebra (Suíça), Kilifi (Quênia) e Gabão (cidade de Lambaréné) e EUA (USA). Os mesmos dados são mostrados nas tabelas suplementares 1 e 2 do item Anexo (item 8.A). 
Figura 1. Reatogenicidade induzida pela vacina VSV-ZEBOV em diferentes coortes.

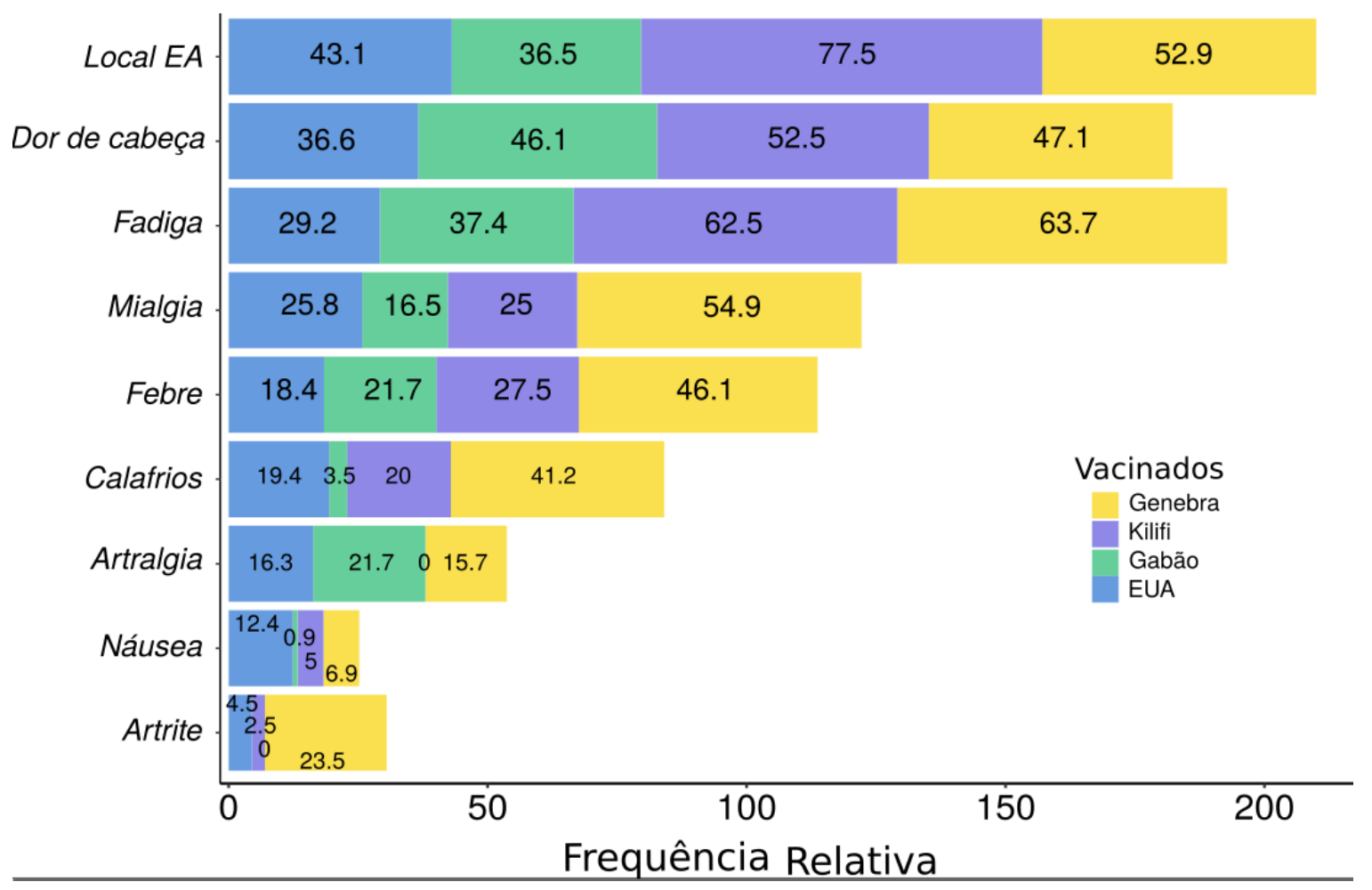

Dados de reatogenicidade relatados nas coortes de Genebra, Kilifi, Gabão e EUA. O gráfico de barras representa a frequência relativa de cada evento adverso para cada uma das coortes presentes neste estudo. O número de cada um dos eventos adversos é representado pelo eixo $x$ e também descrito nas barras. A coorte de Genebra está representada em amarelo $(n=102)$, a coorte de Kilifi em roxo( $n=40)$, a coorte de Gabão em verde $(n=115)$ e a coorte dos EUA em azul $(n=418)$. Local EA é a abreviação para qualquer evento adverso local (dor, inchaço e/ou vermelhidão).

A partir do VEBCON foi criado o VSV-EBOVAC (http://www.vsv-ebovac.eu/) e finalmente o VSV-EBOPLUS, uma extensão do projeto que visa aplicar abordagens de ponta, como imunonômicas, transcriptômicas, miRNômicas e vacinologia computacional para gerar informações chaves para a pesquisa e desenvolvimento de vacina contra Ebola em particular e demais vacinas humanas.

O objetivo geral do VSV-EBOPLUS é decifrar as assinaturas imunológicas e moleculares da resposta altamente protetora induzida em adultos e crianças pela vacina VSV-ZEBOV. Fazem parte desta rede colaborativa as instituições Sclavo Vaccines Association (SVA) (Itália); NewLink Genetics Corp (BPS) (Estados Unidos); University of Geneva (UNIGE) (Suiça); University of Gothenburg (UGOT) (Suécia); University of Siena (UNISI) (Itália); Academisch Ziekenhuis Leiden (LUMC) 
(Holanda); MICROBIOTEC SRL (MBT) (Itália); Eberhard Karls Universitaet Tuebingen (EKUT) (Alemanha); Centre de Recherches Médicales de Lambaréné (CERMEL) (Gabão); Spiez Laboratory, Federal Office for Civil Protection (VBS-LS) (Suiça) e o nosso grupo pertencente à Faculdade de Ciências Farmacêuticas Universidade de São Paulo (USP) (Brasil).

No projeto VSV-EBOPLUS, estão sendo caracterizadas as respostas para a VSV-ZEBOV fase I/ lb/ II de ensaios clínicos, incluindo (I) dose-resposta, (II) coorte pediátrica, e (III) estudos de acompanhamento a longo prazo. Ensaios clínicos com a vacina VSV-ZEBOV já foram realizados em três continentes (África, Europa e América), com quase 1.000 pessoas, entre adultos, crianças e adolescentes, ao longo do período de surtos de Ebola na África. Estes ensaios estão promovendo o entendimento sobre o potencial da vacina VSV-ZEBOV na proteção de grupos de diferentes idades contra a infecção do vírus Ebola.

Além disso, os resultados obtidos ajudarão a elucidar os biomarcadores de memória efetora e memória de longo prazo. O projeto VSV-EBOPLUS busca validar, por geração de novos resultados, os marcadores de reatogenicidade e imunogenicidade que estão sendo identificados na VSV-EBOVAC. Além disso, estão sendo realizadas análises integrativas relacionando os dados clínicos, dados de dose-resposta, ensaios pediátricos e informações imunológicas com dados de resposta imune e análises de transcriptoma.

\subsection{Eventos adversos à vacinação}

A vacinação é frequentemente citada como uma das formas mais eficazes de controlar doenças infecciosas (PLOTKIN, 2014) tendo um expressivo impacto na redução da mortalidade infantil, principalmente nas últimas décadas (ANDRE et al., 2008; CDC, 1999; PREVOTS et al., 2003). Por se tratar de estratégia com bom desempenho em termos de custo-efetividade, possibilita elevada cobertura, igualdade de acesso e segurança, sendo em muitos lugares um componente indispensável em programas de saúde pública (ANDRE et al., 2008; CDC, 1999; POLLARD; BIJKER, 2020). 
No entanto, o sucesso dos programas de imunização cria uma situação contraditória, principalmente em países desenvolvidos, pois à medida que a população vai perdendo a percepção de risco de doenças imunopreveníveis, os temores quanto aos eventos adversos pós-vacinação (EAPV) aumentam. Esta realidade leva à diminuição da adesão à vacinação e permite o reaparecimento de doenças até então controladas (FLANAGAN-KLYGIS; SHARP; FRADER, 2005; LARSON et al., 2014).

A expectativa em relação à segurança das vacinas é mais elevada por serem administradas em pessoas sadias (CLEMENTS; LARSEN; JODAR, 2004; FOLB et al., 2004). Porém, similarmente aos demais produtos farmacêuticos, as vacinas não são inteiramente livres de riscos, o que torna sua segurança um dos fatores determinantes para uma elevada adesão aos programas de imunização (LARSON et al., 2013).

Neste contexto, pesquisas recentes priorizam o desenvolvimento de produtos alternativos menos reatogênicos para evitar eventos adversos às vacinas em desenvolvimento, principalmente no casos de uso emergencial e vacinas recém aprovadas, como é o caso da rVSV-ZEBOV. Dentre as alternativas, o consórcio VSV-EBOPLUS está interessado em encontrar, por meio de abordagens de Vacinologia de Sistemas, assinaturas imunológicas e moleculares que possam diferenciar pessoas que desenvolvem ou não eventos adversos após a vacinação com rVSV-ZEBOV. E principalmente, por métodos de aprendizado de máquina, identificar genes preditores de reatogenicidade, ou seja, cuja expressão antes da vacinação seja capaz de diferenciar pessoas que possam vir a desenvolver eventos adversos.

\subsection{Vacinologia de Sistemas}

A vacinologia de sistemas surgiu como uma área multidisciplinar que visa expandir nossa compreensão dos mecanismos moleculares responsáveis pela eficácia das vacinas (DAVIS et al., 2010; NAKAYA et al., 2015; NAKAYA; PULENDRAN, 2015; POLAND et al., 2013). Esta abordagem baseia-se em capturar toda a complexidade da resposta humana à infecção ou vacinação, com o objetivo 
de obter assinaturas moleculares combinatórias que se correlacionam ou, de preferência, prevejam a imunogenicidade da vacina, bem como sua eficácia em proteger indivíduos de infecções e seus eventos adversos (HAGAN et al., 2015).

Mais especificamente, essa estratégia consiste em utilizar dados de técnicas de larga escala, tais como microarrays e RNA-Seq, para criação de redes de interação e modelos computacionais associados com a imunogenicidade ou a proteção induzida por vacinas. Diversos artigos nessa área foram publicados por nosso grupo, com foco em vacinas como da Febre Amarela (QUEREC et al., 2009; DE LIMA et al., 2019), da influenza (NAKAYA et al., 2011; DE LIMA et al., 2019), da imunodeficiência símia (Kasturi, et al., 2017), e da meningite meningocócica (LI et al., 2014). Porém, ainda faltam estudos de Vacinologia de Sistemas para a vacina rVSV-ZEBOV.

\subsection{Aprendizado de Máquina}

A medicina de precisão é uma área da ciência médica moderna em rápido crescimento e os algoritmos de aprendizado de máquina são um componente crítico para o desenvolvimento bem-sucedido de análises padronizadas e automatizadas de dados de voluntários. Um objetivo importante da vacinologia de precisão é a previsão dos possíveis eventos adversos e até mesmo da possível resposta imunológica a partir dos perfis transcriptômicos individuais de voluntários antes da vacinação.

O termo "aprendizado de máquina" pode ser definido como a capacidade de aperfeiçoar o desempenho de uma máquina na realização de alguma tarefa, por meio da experiência ou identificação de similaridade entre os dados. Ou seja, utilizar de informações prévias para inferir resultados e/ou informações (BENCH-CAPON; DUNNE, 2007). Em um conceito mais amplo cita-se a "inteligência artificial", que se define como o técnicas que permitem ao computador aprender e melhorar seu desempenho em realizar alguma tarefa, simulando o funcionamento do cérebro humano (BENCH-CAPON; DUNNE, 2007).

Dentro do escopo da área estão: a generalização a partir de um conjunto de casos já conhecidos (MICHEIE et al.1994), identificação de agrupamento e 
correlações (EVERITT et al. 2001), reconhecimento de padrões (DUDA et al. 2000), e o refinamento de teorias a partir de métodos de aprendizagem (DZEROSKI; LAVRAC, 2001). Mesmo com grande sobreposição com a estatística tradicional, o aprendizado de máquina tem uma abordagem mais algorítmica, fazendo uso de representações de modelos mais flexíveis e com abordagens mais heurísticas (MICHEIE et al., 1994).

Em resumo, aprendizado de máquina pode ser descrito como um conjunto de práticas voltadas para a solução de problemas, sem o conhecimento preliminar de uma solução ou modelagem capaz de resolver. A partir de um conjunto finito e conhecido de fatos (ou casos) que podem descrever objetos, ambientes, situações, desfechos ou processos, tem-se por objetivo encontrar solução a partir dos mesmos dados. 


\section{Objetivos}

\subsection{Objetivo principal}

Identificar assinaturas moleculares associadas com a reatogenicidade da vacina VSV-ZEBOV contra Ebola administrada em quatro coortes procedentes de estudos clínicos de fase I.

\subsection{Objetivos específicos}

2.2.1. Caracterizar a perturbação molecular induzida após a vacinação com VSV-ZEBOV.

2.2.2. Identificar assinaturas antes da vacinação que predizem reatogenicidade através de algoritmos de aprendizado de máquina. 


\section{Materiais e métodos}

\subsection{Programas computacionais}

Neste trabalho estão sendo utilizados pacotes de bioinformática $\mathrm{e}$ bioestatística disponíveis Bioconductor, um repositório de software para análises de dados de genômica e biologia molecular high-throughput desenvolvido em $\mathrm{R}$ (HUBER et al., 2015). R é uma linguagem de programação de licença aberta focada em estatística computacional e gráfica (R CORE TEAM, 2015). Programas escritos em $R$ são utilizados no pré-processamento, análise e representação gráfica das amostras.

\subsection{Dados Disponíveis do VSV-EBOPLUS}

Dados de quatro estudos clínicos (Genebra - Suíça , Lambaréné - Gabão, Kilifi -Quênia e Estados Unidos) com mais de 1000 adultos vacinados foram coletados por colaboradores do projeto. Amostras de plasma, soro, PBMC (do inglês, Peripheral blood mononuclear cells) e RNA do sangue total de 654 adultos foram coletadas nos dias 0 , 1, 2, 3, 4 e 7 pós-vacinação e amostras adicionais de 175 voluntários adultos da Suíça e de Gabão foram coletadas nos tempos de 14, 28 , $56,84,180$ e 360 dias.

Dentre os adultos incluídos no estudo, 64 voluntários da Suíça tiveram seu transcriptoma sequenciado por meio da plataforma Ion Proton ${ }^{\mathrm{TM}}$ System (Thermo Fisher Scientific) e 375 voluntários tiveram a expressão de 144 genes quantificada a partir do método dcRT-MLPA (HAKS et al., 2015). Na Tabela 1 estão disponíveis informações mais detalhadas sobre as amostras de expressão gênicas disponíveis por coorte em cada tempo de coleta. As doses da vacina ou controle com placebo foram distribuídas da seguinte forma: $1 \times 10^{8}$ pfu (EUA $n=35$ ), $5 \times 10^{7}$ pfu (Genebra $n$ $=16$ ), $2 \times 10^{7}$ pfu (EUA $n=35$, Gabão $n=20$, Kilifi $n=20$ ), $1 \times 10^{7}$ pfu (Genebra $n=$ 35 ), $9 \times 10^{6}$ pfu (EUA $n=35$ ), $3 \times 10^{6}$ pfu (EUA $n=20$, Gabão $n=35$, Kilifi $n=20$ ), $3 \times 10^{5}$ pfu (Genebra $n=51$, Gabão $n=21$ ) e placebo (Genebra $n=13$, EUA $n=19$ ).

Dados demográficos e de reatogenicidade de voluntários adultos saudáveis foram coletadas de 782 participantes, 115 deles de Genebra (102 vacinados e 13 
placebos), 512 dos Estados Unidos da América (418 vacinados e 94 placebos), 115 de Gabão e 40 de Kilifi.

Tabela 1. Dados de expressão gênica disponíveis por coorte.

\begin{tabular}{lcc|cc|cccc}
\hline Coortes & \multicolumn{2}{c}{ Genebra (115) } & \multicolumn{2}{c|}{ Gabão (83 ) } & \multicolumn{2}{c|}{ Kilifi (40) } & \multicolumn{2}{c}{ EUA (140) } \\
\cline { 2 - 8 } & RNA-seq & MLPA & RNA-seq & MLPA & RNA-seq & MLPA & RNA-seq & MLPA \\
\hline Dia 0 & 64 & 115 & - & 83 & - & 37 & - & 140 \\
Dia 1 & 64 & 115 & - & - & - & - & - & 142 \\
Dia 2 & - & - & - & - & - & - & - & 124 \\
Dia 3 & 64 & 115 & - & - & - & - & - & 124 \\
Dia 7 & 63 & 115 & - & 57 & - & 40 & - & 124 \\
Dia 14 & 62 & 114 & - & - & - & - & - & - \\
Dia 28 & 60 & 112 & - & 60 & - & - & - & - \\
Dia 168 & 20 & 113 & - & - & - & - & - & - \\
Dia 365 & - & 95 & - & - & - & - & - & - \\
\hline
\end{tabular}

Os números representam a quantidade de amostras disponíveis. (-): Amostras não coletadas. MLPA: dual-color Reverse Transcriptase Multiplex Ligation-dependent Probe Amplification (dcRT-MLPA).

Ao mesmo tempo, dados imunológicos e clínicos laboratoriais foram coletados e estão sendo processados e analisados por nosso grupo. No entanto, este projeto de Doutorado se restringiu à integração de dados de transcriptoma com dados de reatogenicidade induzidos pela vacina.

\subsection{Dados de RNA-seq}

Os dados de Sequenciamento de Nova Geração (do inglês, NGS) foram disponibilizados apenas para a coorte de Genebra. Esses foram gerados a partir da plataforma Ion Proton ${ }^{\mathrm{TM}}$ System (Thermo Fisher Scientific) pelos nossos colaboradores da Universidade de Siena (UNISI) (Itália) e enviados a nós como arquivo de contagem de expressão gênica. 


\subsubsection{Preparação de biblioteca de transcriptoma e sequenciamento}

Amostras de sangue total foram coletadas em tubos PAXgene ${ }^{\circ}$ blood RNA (BD Biosciences) e o RNA foi extraído utilizando o kit PAXgene Blood RNA Kit IVD (Qiagen) seguindo as instruções do fabricante. A quantificação do RNA total pelo método fluorimétrico Qubit ${ }^{\mathrm{TM}}$ RNA HS Assay kit (ThermoFisher) e a qualidade do RNA por Bioanalyzer (Agilent) foram realizadas pelos colaboradores da Academisch Ziekenhuis Leiden (LUMC - Holanda).

As amostras de RNA foram submetidas ao processo de transcrição reversa e sequenciadas em um Ion Proton ${ }^{\text {TM }}$ System (Thermo Fisher Scientific). As bibliotecas de RNA foram sequenciadas em chips P1v2 usando o sistema lon Proton тм (Thermo Fisher Scientific, \# 4476610), seguido da etapa de purificação. A linha de sequenciadores Ion Torrent baseia-se na detecção de dNTPs (Desoxirribonucleotídeos Fosfatados) por meio de pequenas mudanças no $\mathrm{pH}$. Para isso, são utilizados chips semicondutores de íons que contêm milhões de micropoços, cada um com um sensor de íons para medir mudanças no pH. Para tal, o DNA molde é vinculado a esferas que preenchem cada um dos poços, seguido de inundação de tipos individuais de dNTPs. Quando a DNA polimerase incorpora um dNTP complementar, um íon de hidrogênio é liberado e subsequentemente detectado, resultando em uma chamada de base correspondente. O ciclo das leituras ocorre em paralelo, permitindo um sequenciamento preciso e de alto rendimento. O sequenciamento foi concluído pelo Recurso Compartilhado da Universidade de Siena.

\subsubsection{Pré-processamento de dados de RNA-seq}

Todas as amostras foram alinhadas com o Programa de Alinhamento de Mapeamento do próprio Ion Proton ${ }^{\mathrm{TM}}$ usando o genoma de referência humano. As etapas de pré-processamento dos dados gerados com o sequenciamento foram feitas com o software próprio do sistema lon Proton seguindo as instruções de uso do mesmo. Consistente com a tecnologia de sequenciamento Ion Proton, todas as leituras foram tratadas como single-end para fins de alinhamento do genoma e contagem de atributos. 


\subsubsection{Avaliação da variabilidade dos dados}

Em dados de sequenciamento de nova geração, a acurácia e a precisão são influenciados por diversos fatores, como variação da cobertura, efeito de lote, bem como, erros na sequência resultante (OWZAR et al., 2008; TAUB; CORRADA BRAVO; IRIZARRY, 2010). Para avaliar a variabilidade das amostras, verificamos a presença de efeito de lote e identificação de possíveis amostras outliers pela análise de componentes principais (PCA) (Pearson, 1901; Hotelling, 1933), que permite avaliar as distâncias relativas das amostras no plano de suas componentes principais. Com o PCA é possível detectar outliers, ou seja, amostras que possuem uma dispersão muito diferente em relação às demais, e também agrupamentos de amostras que possivelmente refletem variáveis técnicas, como data do experimento ou scanner utilizado. A PCA foi obtida a partir da função prcomp disponível no R.

Um outro recurso para se estimar os principais efeitos responsáveis por essa variabilidade experimental é conhecido como Análise dos Componentes Variantes Principais (PVCA, do inglês Principal Variance Component Analysis). Assim como o PCA, o PVCA também é uma análise não-supervisionada, e tem o objetivo a redução da dimensão dos dados por meio da manutenção de sua variação original e ajuste de modelo linear misto com fatores de interesse. Para tal fim, age como efeitos aleatórios de modo a determinar qual seu peso na variabilidade total. Este método está implementado no pacote PVCA do Bioconductor (Bushel, 2019).

\subsubsection{Análise de expressão diferencial}

A detecção de genes diferencialmente expressos (DEGs, do inglês, differentially expressed genes) entre voluntários vacinados antes e depois da vacinação fornece pistas importantes sobre o que acontece durante a resposta imunológica induzida pela vacina ao longo do tempo. O Teste T de Student permite avaliar se há diferença entre a média de expressão de um gene entre duas classes. Porém, pode ocorrer que a estimativa da variância seja próxima de zero devido ao acaso levando erroneamente a altos valores absolutos de $\mathrm{T}$ e, consequentemente, a falsos positivos (TARCA; ROMERO; DRAGHICl, 2006). Deste modo, foi utilizado o pacote para R do Bioconductor DESeq2 (LOVE; HUBER; ANDERS, 2014) que foi 
desenvolvido para analisar com dados obtidos em sequenciamento de nova geração (NGS) e consequentemente lidar com a alta dimensionalidade dos dados, reduzindo falsos-positivos.

Definimos DEGs como sendo os genes com $p$-valor abaixo de um limiar $(p<$ 0.05) e Log2 (fold-change, FC) absoluto acima de um limiar ( $F C>2)$. Um gene é considerado sub-expresso (com regulação diminuída) quando sua expressão média é maior no grupo controle, e sobre-expresso (com regulação aumentada), quando sua expressão média for maior no grupo perturbado.

\subsubsection{Análise de Enriquecimento de vias}

Os DEGs sobre-expressos ou sub-expressos encontrados na etapa anterior foram utilizados na análise de enriquecimento funcional. Nesta análise utilizamos o Reactome, um banco de dados de vias gênicas e que fornece detalhes a nível molecular da transdução de sinais, replicação do DNA, metabolismo e outros processos celulares (FABREGAT et al., 2018). A significância do enriquecimento é obtida pelo teste exato de Fisher. Para estas análises de sobre representação utilizamos a função enrichr do pacote clusterProfiler do R, bem como a ferramenta de mesmo nome disponível online (https://maayanlab.cloud/Enrichr/).

Outra maneira de avaliar o enriquecimento em dados de expressão gênica é por meio do método conhecido como Gene Set Enrichment Analysis (GSEA) (SUBRAMANIAN et al., 2005). Neste método não é necessário definir os genes diferencialmente expressos previamente. Os genes são ordenados de acordo com um score como Log2 do fold-change, valor de $\mathrm{T}$ ou $\mathrm{p}$-valor. Posteriormente, verificamos se os genes membros de um determinado módulo estão distribuídos aleatoriamente na lista ordenada. Caso os genes do módulo estejam no início ou no final da lista, o módulo é considerado enriquecido.

Uma outra vantagem em usar este tipo de análise é que permite revelar maior similaridade entre estudos independentes, já que uma mesma via gênica alterada pode envolver genes diferentes (KHATRI; SIROTA; BUTTE, 2012;SUBRAMANIAN et al., 2005). Esta análise foi realizada utilizando o pacote 
fgsea (SERGUSHICHEV, 2016), que otimiza a análise fazendo o cálculo dos valores estatísticos de enriquecimento cumulativos de genes, o que permite calcular rapidamente múltiplos valores estatísticos de amostras a partir de uma única amostra.

A análise GSEA utiliza os resultados gerados pela etapa de análise de expressão diferencial e extrai os valores de Log2 do fold-change de cada comparação. Caso haja mais de um valor para um mesmo gene, o maior valor é selecionado (SUBRAMANIAN et al., 2005). Neste trabalho, o pacote fgea disponível no programa $R$ foi usado para as análises.

\subsubsection{Análise de Redes de interação proteína-proteína}

Como forma de melhor compreender os padrões de perturbação de maneira sistêmica, foi utilizado a ferramenta NetworkAnalyst (XIA; GILL; HANCOCK, 2015), um framework online que permite a visualização de redes a partir do banco de dados de interações proteína-proteína (PPI) InnateDB (BREUER et al., 2013). Para tal, foram construídas redes com genes sobre-expressos nas comparações com o tempo inicial. Com o propósito de melhorar a visualização, os softwares Cytoscape e Gephi também foram utilizados (BASTIAN; HEYMANN; JACOMY, 2009; SHANNON et al., 2003).

\subsubsection{Análise de Redes de Coexpressão}

A identificação de redes de genes coexpressos é uma importante abordagem para encontrar genes regulatórios, fazer novas associações entre genes e processos biológicos e até mesmo eleger candidatos a alvo de vacinas (RUSSO et al., 2018).

A rede de coexpressão interliga os genes (os nós da rede) entre si, a partir de uma medida de similaridade entre os genes que pode ser dada pelo valor da correlação de Pearson entre a expressão dos genes em questão (ZHANG; HORVATH, 2005). A partir da formação das redes, os genes mais correlacionados agrupam-se em módulos, que se ativam de maneira simultânea, participam das 
mesmas vias gênicas e atuam regulando as diferenças fenotípicas associadas à perturbação em estudo (ZHANG; HORVATH, 2005).

Redes de coexpressão têm permitido compreender cada vez mais os sistemas biológicos e os mecanismos moleculares que os regem. A fim de se encontrar módulos biologicamente interessantes, o aspecto regulatório pode ser melhor investigado com informações externas, como informações de interações proteína-proteína, interações entre fatores de transcrição, enriquecimento de vias, Gene Ontology, entre outros (GLASS et al., 2013).

Neste trabalho, esta análise foi executada com o pacote do R CEMiTool (RUSSO et al., 2018) em dados de RNA-seq normalizados por Log2CPM com o também pacote do R EdgeR (LOVE; HUBER; ANDERS, 2014) e em dados de dcRT-mlpa normalizados e log2 transformados. O CEMiTool é um pacote baseado no WGCNA, um algoritmo é construído em agrupamento hierárquico, onde a construção do módulo é baseada nas correlações do gene e, a partir de medidas de correlação de Pearson, calcula a conectividade dos genes e a sobreposição topológica, possibilitando a determinação de módulos pelo agrupamento dos genes mais similares (Zhang; Horvath, 2005).

Além da identificação dos módulos de genes coexpressos, foi possível compreender quais genes estão mais representados por uma via específica ou estão sendo alterados em apenas um subconjunto de amostras. Desta forma, foi possível identificar genes que podem estar agindo juntos e/ou podem estar sendo regulados de maneira similar e identificando os principais reguladores, promovendo assim um melhor entendimento da fisiopatologia da resposta à vacinação com VSV-ZEBOV.

\subsection{Dados de dcRT-MLPA}

Para investigar ainda mais os perfis transcriptômicos humanos da resposta à vacina rVSV-ZEBOV, nossos colaboradores da Academisch Ziekenhuis Leiden (LUMC) (Holanda) utilizaram a plataforma quantitativa multiplex RT-PCR, que faz amplificação por meio de sonda ligação-dependente de duas cores (dcRT-MLPA). 
Sangue venoso foi coletado em tubos de PAXgene de $2.5 \mathrm{~mL}$ para extração de RNA de sangue (PreAnalytiX, Hombrechtikon, Suíça) e armazenado a $-80^{\circ} \mathrm{C}$. $\mathrm{O}$ RNA foi isolado usando o kit de miRNA de sangue PAXgene (PreAnalytiX) de acordo com o protocolo automatizado do fabricante, incluindo digestão de DNase em coluna. O rendimento do RNA foi quantificado com um fluorômetro Qubit (ThermoFisher, Wilmington, DE, EUA) usando um kit de ensaio RNA Broad Range (ThermoFisher), conforme descrito por Huttner e colaboradores (2017) (HUTTNER et al., 2017).

O ensaio dcRT-MLPA (MLPA) tem como cobertura genes com importância crítica documentada em respostas imunes inatas e adaptativas (HAKS et al., 2015) e foi utilizado para determinar a expressão gênica imunológica induzida por VSV-ZEBOV. O MLPA é uma técnica rápida, confiável, robusta, de baixo custo e fácil de usar, permitindo o perfil de expressão de mRNA de aproximadamente 80 loci por reação (HAKS et al., 2015). Estudos mostraram que o MLPA tem dinâmica e sensibilidade muito próximas da RT-qPCR (HAKS et al., 2015; JOOSTEN et al., 2012; LA DISTIA NORA et al., 2018; SLOOT et al., 2015). Um passo de amplificação por PCR dentro de dcRT-MLPA assegura a sensibilidade do ensaio, que é um pré-requisito essencial para a quantificação relativa de genes pouco expressos (HAKS et al., 2015; JOOSTEN et al., 2012; LA DISTIA NORA et al., 2018; SLOOT et al., 2015).

O MLPA é concebido de tal modo que todos os fragmentos são amplificados com a utilização de dois pares de iniciadores de PCR conjugados com fluoróforo, enquanto que o comprimento de cada produto de amplificação é único. $O$ ensaio proporciona uma separação ótima de fragmentos e um ruído baixo em géis de sequência onde a intensidade de fluorescência de cada produto de amplificação é quantificada. Como o ensaio MLPA é de alto rendimento (formato de 96 poços) e requer apenas $100 \mathrm{ng}$ de RNA por amostra, é muito adequado para a realização de análises de expressão gênica de média escala em coortes maiores, incluindo análises longitudinais (HAKS et al., 2015).

Utilizando como base dados da análise integrativa de dados de RNA-seq e imunogenicidade/reatogenicidade, um arranjo personalizado de MLPA foi projetado. 
Este cobriu os genes mais importantes da análise integrativa, e as amostras de RNA foram submetidas a esta matriz personalizada para validação. Isso permitiu o perfil transcriptômico mais amplo de muitas amostras de todas as coortes derivadas de indivíduos coletados em diferentes momentos após a vacinação (HAKS et al., 2015; HUTTNER et al., 2017).

Os genes iniciais incorporados avaliam os seguintes compartimentos da resposta imune humana: resposta imune inata, adaptativa, inflamatória e de sinalização de interferon e alguns outros genes sabidamente envolvidos em processos como apoptose/sobrevivência celular, proteínas de ativação, estresse mitocondrial, transporte intracelular, entre outros, permitindo a obtenção de conjuntos de 144 genes (HAKS et al., 2015).

\subsubsection{Pré processamento de dados de dcRT-MLPA}

A partir dos valores de expressão gerados pelo método, os valores de expressão gênica foram normalizados de acordo com a expressão dos genes housekeeping e os valores foram transformados para log2. Para análises envolvendo aprendizado de máquina, o efeito de lote foi removido. Este foi removido utilizando a função removeBatchEffect disponível no pacote Limma do R. A tabela com os dados log2 transformados foi utilizada como entrada e os argumentos batch e batch2 foram a coorte e a dose, respectivamente.

\subsubsection{Avaliação da variabilidade dos dados}

A variabilidade dos dados de dcRT-MLPA foi avaliada de acordo com 0 descrito no item 3.3.3.

\subsubsection{Análise de expressão diferencial}

A análise de expressão diferencial foi realizada com 0 teste de Mann-Whitney não pareado, com correção de Benjamini-Hochberg. Neste caso, definimos DEGs como sendo genes com $p$-valor abaixo de um limiar $(p<0.05)$ e Log2 (fold-change) absoluto acima de um limiar ( $F C>1.5$ ). 
Como estamos analisando diferentes coortes, as listas de DEGs obtidas a partir dos dados de cada coorte, foram comparadas entre si a fim de averiguar a concordância entre as mesmas. A sobreposição de DEGs entre as coortes foi avaliada através de diagramas de Venn construídos com a plataforma online Venny 2.1 (OLIVEROS, 2007).

\subsubsection{Enriquecimento de vias}

Os genes diferencialmente expressos foram utilizados na análise de enriquecimento funcional como descrito no item 3.3.5.

\subsubsection{Análise de Redes de Coexpressão}

As redes de genes coexpressos foram identificadas conforme descrito no item 3.3.7.

\subsection{Integração de dados de expressão gênica e reatogenicidade}

A análise de dados de expressão gênica permite a identificação de grupos significativos de genes com funcionalidades relacionadas (NASCIMENTO; TOLEDO; DE CARVALHO, 2010). Os genes com expressão alterada podem melhorar nossa compreensão do mecanismo de formação da perturbação. Esta pode ser causada por uma infecção, vacina, estresse, entre outros, permitindo prever o risco de ser afetado por determinada doença (LATKOWSKI; OSOWSKI, 2015). A integração de dados de expressão gênica com informações de reatogenicidade pode possibilitar o entendimento da regulação desses eventos em nível transcricional.

Como nesta fonte de dados o número de amostras é uma ordem de magnitude menor que um número de variáveis, existem muitos problemas no processamento de dados biológicos. Tais dados são difíceis de analisar com métodos estatísticos tradicionais, que funcionam bem quando um número de atributos que descrevem objetos $(p)$ é muito menor que o número de objetos $(n)$ (KURSA; JANKOWSKI; RUDNICKI, 2010).

A análise de $p$ grandes e $n$ pequenos é frequentemente realizada usando algoritmos de aprendizado de máquina, como Redes Bayesianas, Redes Neurais, 
Support Vector Machine (SVM), entre outros, por meio da construção de modelos preditivos.

Levando isso em consideração, para integrar essas informações de reatogenicidade com o valor de expressão dos genes de voluntários antes da vacinação com VSV-ZEBOV, foram utilizadas abordagens de aprendizado de máquina com o intuito de avaliar o valor preditivo dos genes no desfecho. As etapas do processo de definição de modelos preditivos são mostradas na Figura 2.

Figura 2. Fluxograma para a definição e avaliação de modelos preditivos.

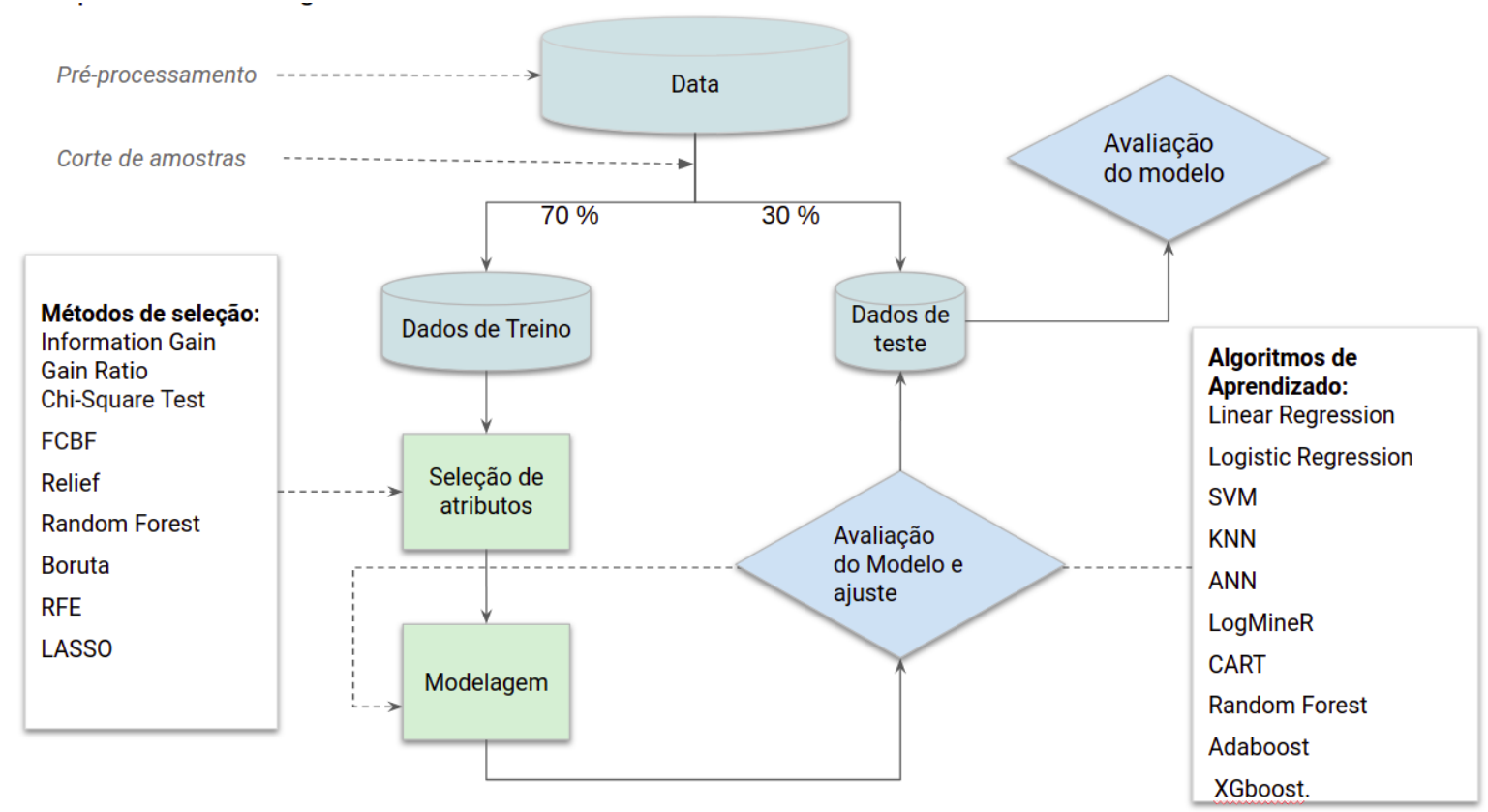

O fluxograma mostra as etapas e os métodos utilizados na definição de modelos preditivos. Os dados de expressão obtidos por MLPA ou RNA-seq são particionados em dados de treino $(70 \%)$ e dados de teste $(30 \%)$. Diferentes métodos de seleção de atributos são aplicados aos dados de treino para a seleção dos atributos melhor ranqueados. A partir do subconjunto do treino (apenas os atributos selecionados), aplicam-se algoritmos de aprendizado de máquina e definem-se diferentes modelos preditivos. É o selecionado o algoritmo com o qual se obteve o modelo predito com melhor avaliação. Os hiperparâmetros deste modelo são ajustados ainda com os dados de treino, e o desempenho deste modelo é posteriormente avaliado utilizando os dados de teste. O modelo com melhor desempenho preditivo tanto nos dados de treino e de teste é o escolhido. 


\subsubsection{Pré-processamento dos dados}

Uma vez que a maioria dos algoritmos de aprendizado extrai conhecimento exclusivamente dos dados, a qualidade do conhecimento gerado é determinada quase que exclusivamente pela qualidade dos dados de entrada, sendo esta uma das principais preocupações para a determinação de um modelo preditivo.

Levando isso em conta, algumas etapas de pré-processamento dos dados foram realizadas a fim de garantir a qualidade dos mesmos. Os dados de expressão gênica devidamente normalizados, de acordo com as exigências de cada uma das plataformas e a informação de idade de cada voluntário constituíam os dados contínuos. Para garantir que todos os atributos tivessem a mesma média e desvio padrão 0 e 1, respectivamente, foi aplicada a transformação de Z-score. Vale ressaltar que este processo de escalonagem dos dados foi feito para os dados de treino e de teste separadamente, a fim de evitar vazamentos de dados do subconjunto de treino para o subconjunto de teste. A padronização dos dados contínuos é uma etapa imprescindível, já que variáveis com alta escala podem afetar a qualidade da predição, considerando que alguns algoritmos podem priorizar variáveis com valores mais altos e serem mais lentos ao lidar com variáveis não padronizadas (GOLDSCHMIDT \& PASSOS, 2005).

Dados demográficos como etnia e coorte pertencente foram utilizados como atributos. Por serem categóricos, foram construídas variáveis artificiais que passaram a assumir valores de ausência ou presença dos atributos (0 ou 1) que são conhecidas pela literatura como variáveis dummy, utilizando pacotes do $\mathrm{R}$ fastDummies (KAPLAN \& SCHLEGEL. 2019) e dplyr (WICKHAM et al. 2018).

Dentre as funções do pré-processamento está a busca por padrões ou modelos para tratar o conhecimento obtido, mas para isso é exigida a validação dos mesmos. Para isso, os dados são divididos em conjuntos para treinamento e para teste. O conjunto de treinamento deve conter, como o nome sugere, os registros a serem utilizados no treinamento do modelo, ou seja, na construção do mesmo, enquanto o conjunto teste deve conter os registros a serem utilizados na avaliação do modelo (GOLDSCHMIDT \& PASSOS, 2005). Neste trabalho, foram utilizados 
$70 \%$ do conjunto de dados para o treino e os $30 \%$ restantes para o teste. Como ilustrado previamente na figura 2.

\subsubsection{Seleção de atributos}

A seleção de atributos é uma tarefa de grande importância no processo de extração de conhecimento a partir de bases de dados. Esta baseia-se, como o próprio nome indica, em selecionar um subconjunto dos atributos de entrada para treinar o modelo, ignorando atributos irrelevantes ou redundantes (KIRA \& RENDELL, 1992). Tem como objetivo simplificar os modelos e facilitar a interpretação dos mesmos por pesquisadores, bem como diminuir o tempo de treino, reduzir a dimensionalidade dos dados e aumentar a generalização do modelo reduzindo o sobreajuste (BORGES; NIEVOLA, 2012). Em estudos de expressão de genes pode melhorar a compreensão dos resultados produzidos, avaliando a influência de cada um dos atributos selecionados (BORGES; NIEVOLA, 2012). São utilizadas quatro principais abordagens no método de seleção de atributos, denominadas Filtro (DAS, 1971), Wrapper (KOHAVI; JOHN, 1997), Embutida (CHEN et al., 2009) e Métodos Híbridos (ESSEGHIR, 2010), que se diferem pela forma como eles combinam o algoritmo de seleção e a construção do modelo.

Resumidamente, a estratégia de Filtro seleciona os atributos independentemente do algoritmo de aprendizado, enquanto que na de Wrapper o processo de escolha do subconjunto de atributos está "empacotado" ao algoritmo de aprendizado utilizado. Nesta estratégia, é utilizado algum critério interno do algoritmo que faz seleção de atributos, enquanto nos métodos híbridos propriedades de filtro e wrappers são combinadas (MALDONADO; LÓPEZ, 2018).

Para a seleção de genes preditores foram utilizados diferentes métodos de seleção de atributos, sendo os baseados em filtro: Information gain (Hoque et al. 2014), Gain ratio (Witten and Frank, 2011), Correlação (YU \& LIU, 2003), minimum Redundancy maximal Relevance (mRmR - praznik) (BROWN et al., 2012), Fast correlation-based filter (FCBF - FCBF) e Relief (Fselector) (KIRA \& RENDELL, 1992). Os métodos baseados em Wrapper foram: Random Forest, Boruta, Recursive Feature Elimination (RFE). Finalmente, o método baseado em embutido 
e híbrido utilizado foi o Lasso. Todos os algoritmos utilizados foram implementados em funções disponíveis em $\mathrm{R}$.

Também selecionamos atributos em comum entre os dados de RNA-seq e MLPA, reduzindo a quantidade de atributos no primeiro e avaliando o impacto da forma de obtenção dos dados na qualidade do modelo preditivo. O método de seleção de atributos foi definido como o melhor para cada conjunto de dados, a partir da avaliação obtida com os atributos selecionados em modelos preditivos.

\subsubsection{Definição de Modelos preditivos}

Para a definição de modelos capazes de predizer voluntários com artrite, aplicamos diferentes algoritmos de aprendizado de máquina, implementados no pacote caret do R (KUHN et al., 2016). Como a predição estava direcionada a uma classe categórica, ou seja, com ou sem evento adverso e havia informação sobre o desfecho, usamos algoritmos de classificação supervisionados.

Dado uma distribuição infinita de dados, um algoritmo pode ter melhor desempenho do que outro a depender do conjunto de dados utilizado. Por este motivo aplicamos aos dados diferentes algoritmos de aprendizado de máquina dentre eles CART ("rpart"), k-Nearest Neighbors ("kNN"), Support Vector Machines with Radial Basis Function Kernel ("svmRadial"), Random Forest ("rf"), eXtreme Gradient Boosting ("xgbTree"), AdaBoost Classification Trees ("Adaboost"), Bayesian Generalized Linear Model ("bayesglm"), Boosted Classification Trees ("Ada"), Neural Network ("'nnet'") e Stacked AutoEncoder Deep Neural Network ("dnn"). A qualidade da predição dos dados de teste foi avaliada principalmente pelos valores de sensibilidade, especificidade e área abaixo da curva (AUC, do inglês, Area Under the Curve) ROC (do inglês, Receiver Operating Characteristic). 


\section{Resultados}

\subsection{Dados de RNA-seq}

\subsubsection{Avaliação da variabilidade dos dados}

O método PCA foi utilizado para a redução de dimensionalidade dos dados. A Figura 3 mostra a variabilidade das amostras obtida a partir dos dados de expressão após a normalização de acordo com o grupo (Dose $1 \times 10^{7}$, Dose $5 \times 10^{7}$ e placebo) (Figura 3A) e de acordo com os dias $(0,1,2,3,7,14,28,168)$ após a imunização (Figura 3B). A dispersão das amostras não demonstra uma clara separação dos indivíduos quanto a dose de vacina (Figura 3A), mas sim uma gradual segregação quanto ao tempo de coleta, observando-se maior separação entre amostras do dia 1 em relação aos demais tempos (Figura 3B).

\section{Figura 3. Análise de componentes principais das amostras de RNA-seq.}

A

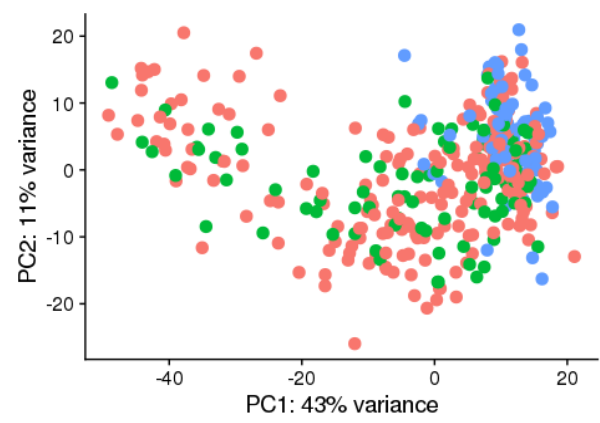

B

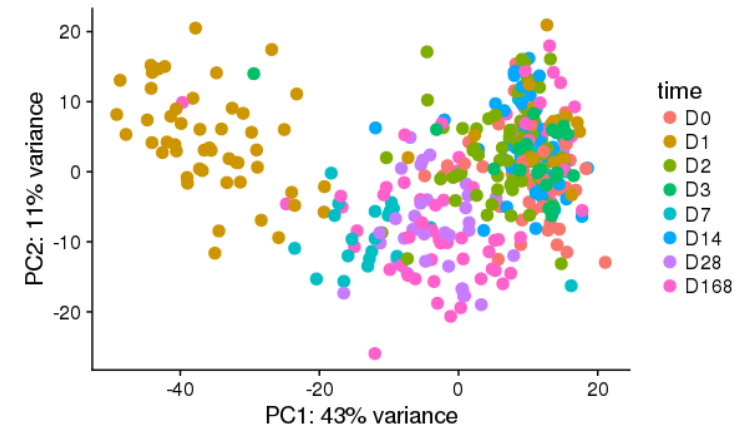

Análise de componentes principais a partir de dados de RNA-seq de voluntários vacinados e placebo em todos os tempos de análise quando identificados por $(A)$ dose e $(B)$ tempo de coleta. $\mathrm{Na}$ figura $\mathrm{A}$, as amostras de voluntários que receberam a dose de $1 \times 10^{7}$ estão representadas em vermelho, as dos que receberam a dose $5 \times 10^{7}$ estão representados em verde e as dos que receberam a dose placebo estão representados em azul. Na figura $B$ as amostras estão identificadas de acordo com os dias após a vacinação. As amostras do dia 0 (D0) estão representados em vermelho, as do dia 1 (D1) em amarelo, as do dia 2 (D2) em verde musgo, as do dia 3 (D3) em verde, as do dia dia 7 (D7) em verde água, as do dia 14 (D14) em azul, as do dia 28 em roxo e finalmente, as do dia 168 (D168) em rosa. O eixo $\mathrm{x}$ representa a dispersão das amostras no componente principal 1 (PC1) enquanto o eixo $Y$ representa a dispersão das amostras no componente principal 2 (PC2). 
Para estimar o efeito de cada variável nos resultados experimentais, foi realizada a análise de PVCA. Esta análise determina quais fontes de variabilidade (biológicas, técnicas ou outras) são mais proeminentes no conjunto de dados de RNA-seq. Neste conjunto, a maior parte de toda variabilidade (76\%) não é explicada por nenhum dos atributos definidos (chamada então de "resíduo"). As variáveis que melhor explicam a variabilidade dos dados neste modelo são "idade e gênero" (7\%), e "lote de sequenciamento" (6\%) (Figura 4). Como a proporção da variância do efeito do sequenciamento foi baixa, não foi necessário aplicar nenhum método para retirar efeito de lote. O gráfico de PVCA evidenciou que a maior parte da variação dos dados não é explicada pelas condições experimentais, ou mesmo efeitos de grupo, mas sim fatores intrínsecos à natureza dos dados e variabilidade populacional.

Figura 4. PVCA dos dados de RNA-seq obtidos com a coorte de Genebra.

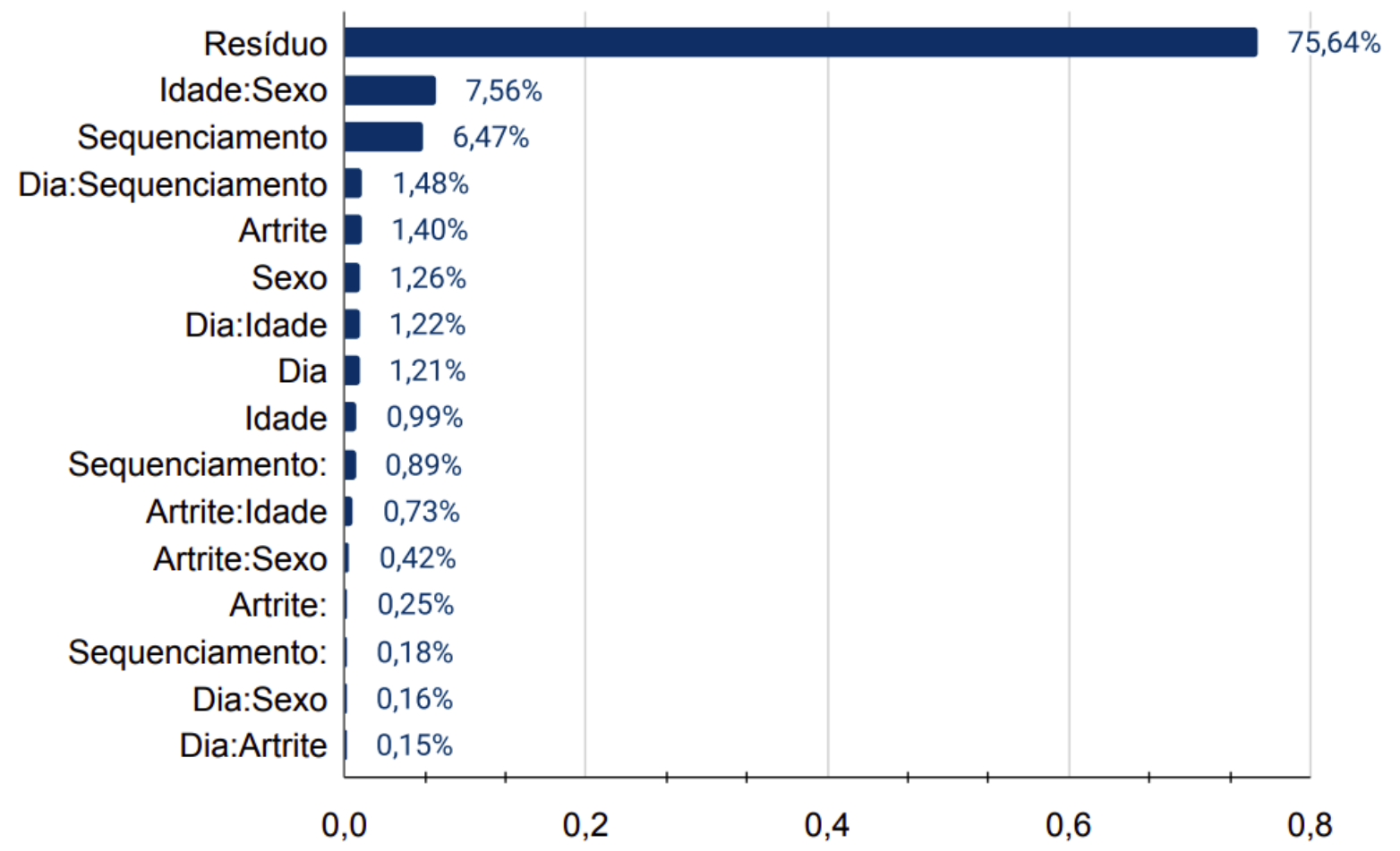

Gráfico de barras mostrando a proporção de variância explicada por cada uma das variáveis explicitadas na figura. $\mathrm{O}$ eixo $\mathrm{x}$ representa o valor de proporção de variância explicada por cada uma das variáveis do eixo y. Os valores obtidos para cada variável, ou combinação de variáveis estão disponíveis na figura. 


\subsubsection{Análise de expressão diferencial}

A análise de expressão diferencial entre voluntários antes (dia 0) e depois da imunização (dias 1, 3, 7, 14, 28 e 168) foi realizada a partir dos dados de expressão brutos que foram processados e analisados utilizando o pacote DESeq2 (LOVE; HUBER; ANDERS, 2014). Os genes foram considerados significativamente diferencialmente expressos (DEGs) seguindo os critérios de $p$-valor ajustado $<0.05$ e valor absoluto de Log2 fold-change $>2$.

A Figura 5 ilustra a quantidade de DEGs em cada tempo de coleta. Em relação ao tempo inicial (antes da vacinação). A comparação com maior número de DEGs foi com o dia 1 (365, sobre-regulados), seguido do dia 7, com 79 DEGs sendo 75 destes sobre-expressos e quatro sub-expressos.

Figura 5. Número de genes diferencialmente expressos por tempo de coleta após a vacinação com VSV-ZEBOV.

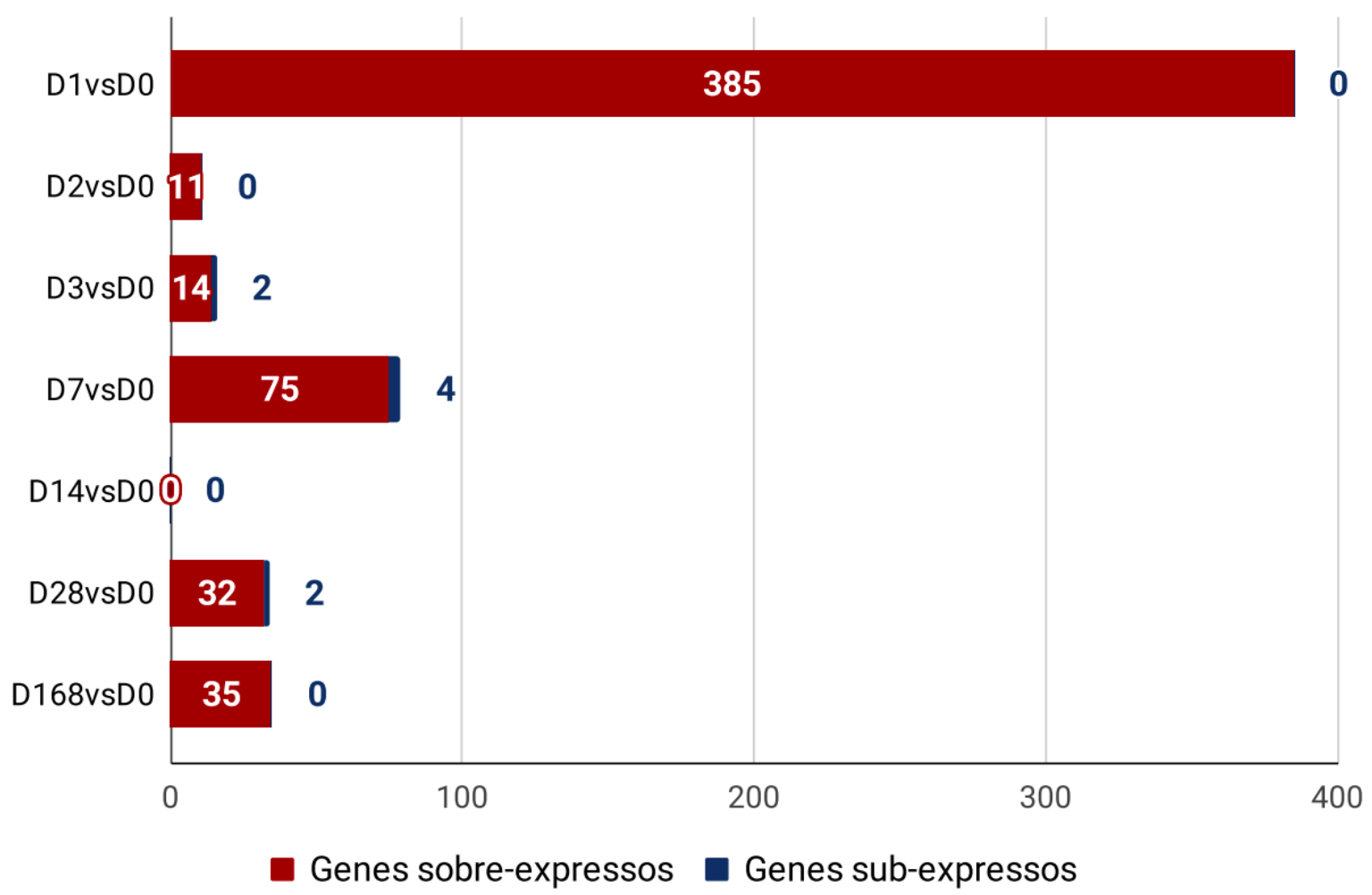

A quantidade de genes sobre-expressos (UP) é representada em vermelho e a quantidade de genes sub-expressos (DOWN) é representada em azul. O eixo $\mathrm{x}$ representa o número absoluto de genes obtidos a partir da análise de expressão diferencial. Estes valores foram obtidos pela comparação de cada um dos dias de avaliação em relação ao tempo inicial (dia $0)$. 
A fim de avaliar a co-ocorrência dos DEGs de cada comparação, fizemos uma matriz de similaridade. Nesta, a maior porcentagem dos DEGs é compartilhada entre os tempos D1 e D7 (45 genes, o que corresponde a $60 \%$ dos DEGs do dia 7) em comparação ao tempo inicial D0 (dados não mostrados).

\subsubsection{Análise de Enriquecimento funcional (Sobre representação)}

Para colocar a lista de DEGs em um contexto biológico, foram feitas análises de enriquecimento utilizando o teste exato de Fisher e os bancos de dados do Reactome (FABREGAT et al., 2018). Os resultados sugerem (Figura 6) que logo no primeiro dia pós-vacinação, os genes sobre-expressos estavam enriquecidos principalmente para as vias de ativação do IRF7 dependente de TRAF6, de sinalização de IFN- $\gamma$ e de resposta imune inata. 
Figura 6. Análise de sobre representação de vias enriquecidas de DEGs encontrados 1 dia após a imunização dos voluntários.

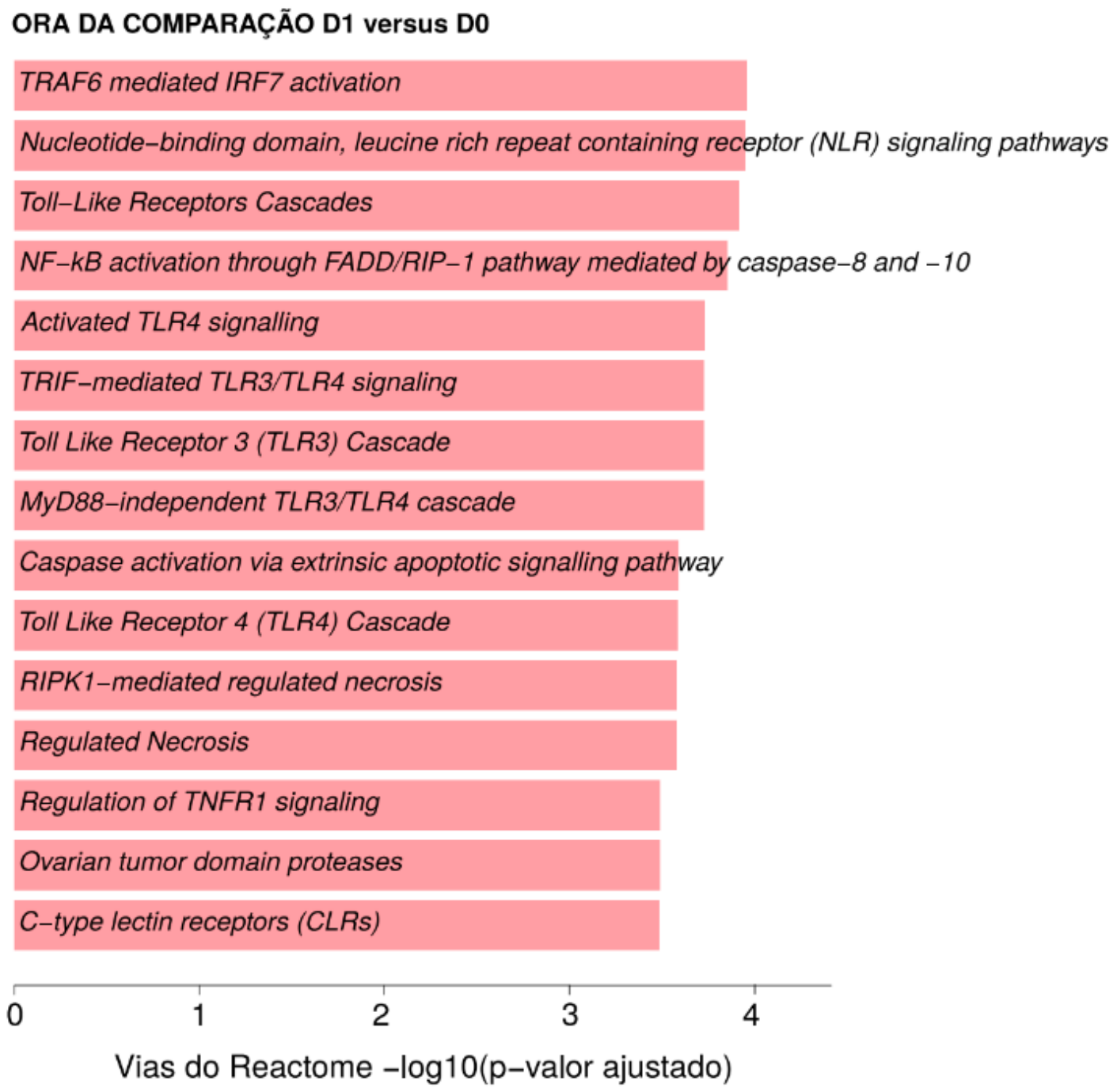

São mostrados na figura as 15 vias com maior valor de -log10 ( $p$-valor ajustado). ORA: Over Representation Analysis.

Esse perfil de resposta é mantido nos dias 2 e 3 . No dia 7, os genes sobre expressos estavam enriquecidos para vias de degradação de neutrófilo, bem como, para vias envolvendo reguladores negativos dos genes RIG-I (do inglês, The RNA helicases retinoic acid-inducible gene I) e o gene MDA5 (do inglês, melanoma differentiation-associated gene 5) envolvidos na detecção de RNAs virais citoplasmáticos e na indução de interferon $\alpha / \beta$. Também foram enriquecidos para 
vias de indução de respostas imunes do hospedeiro mediada por STING (do inglês, Stimulator of interferon genes).

Figura 7. Resultado da análise de sobre representação de vias enriquecidas em voluntários 7 dias após a imunização.

\title{
ORA DA COMPARAÇÃO D7 versus DO
}

\author{
Neutrophil degranulation \\ Negative regulators of RIG-I/MDA5 signaling \\ RIG-I/MDA5 mediated induction of IFN-alpha/beta pathways \\ STING mediated induction of host immune responses \\ $N F-k B$ activation through $F A D D / R I P-1$ pathway mediated by caspase- 8 and -10 \\ TRAF3-dependent IRF activation pathway \\ Interleukin-1 signaling
}

Regulation of innate immune responses to cytosolic DNA

Eicosanoid ligand-binding receptors

Nicotinate metabolism

Cytosolic sensors of pathogen-associated DNA

Interleukin-10 signaling

Formation of Senescence-Associated Heterochromatin Foci (SAHF)

Nicotinamide salvaging

Ephrin signaling

$\begin{array}{llllllll}0.0 & 0.5 & 1.0 & 1.5 & 2.0 & 2.5 & 3.0 & 3.5\end{array}$

Vias do Reactome -log10(p-valor ajustado)

São mostrados na figura as 15 vias com maior valor de -log10 ( $p$-valor ajustado). ORA: Over Representarion Analysis. 


\subsubsection{Análise de Enriquecimento de Gene sets (GSEA)}

A Análise de Enriquecimento de Gene Set é um método computacional que determina se um conjunto de genes definido a priori apresenta significância estatística entre dois estados biológicos. Neste trabalho, os grupos são compostos de voluntários antes e depois da imunização com rVSV-ZEBOV. As vias com maiores valores de enriquecimento (suportadas por p-valor < 0.01) para os DEGs no dia 1 estão representados na Figura 8. Dentre as vias com maior valor de enriquecimento estão as relacionadas à sinalização de interferon e todas apresentaram um valor positivo de escore de enriquecimento normalizado (NES, do inglês normalized enrichment score). Valores positivos de NES demonstram que os genes desta via estão em sua maioria sobre-regulados.

Figura 8. Análise de GSEA da comparação de voluntários no dia 1 pós-vacinação com VSV-ZEBOV em relação aos voluntários antes da vacinação (dia 0 ).

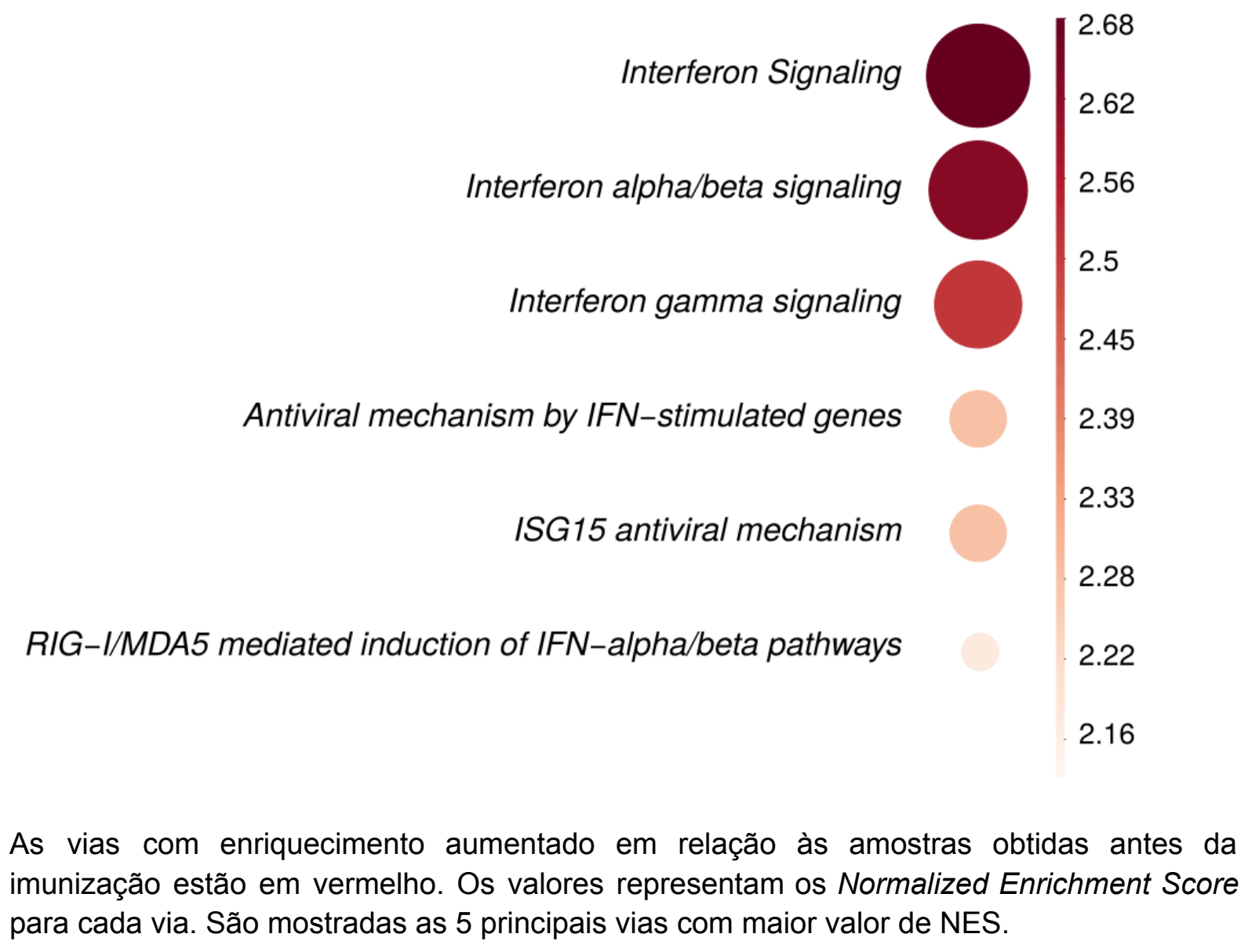


Estas vias de resposta imune inata foram induzidas do dia 1 ao dia 14. Nos dias 2 e 3 pós-vacinação, as vias descritas na literatura como envolvidas em respostas de neutrófilos estavam sub-reguladas, ao passo que as vias descritas como relacionadas com o sistema complemento estavam sobre-regulados. Vias relacionadas a células $\mathrm{T}$ e ao ciclo celular foram encontradas reguladas positivamente nos dias 7 e 14 , enquanto no dia 28 , nenhuma via permanece ativada.

\subsubsection{Análise de rede de interação proteína-proteína}

A lista de DEGs do dia 1 foi submetida ao software Network Analyst (XIA; GILL; HANCOCK, 2015) com o objetivo de avaliar a conexão desses 385 genes entre eles e com demais genes. Os resultados desta análise evidenciam o papel dos genes FBXO6 (do inglês, F-Box Protein 6), HSPA1B (do inglês, Heat Shock $70 \mathrm{KDa}$ Protein 1B), HSPA1A (do inglês, Heat Shock 70 KDa Protein 1A), MOV10 (do inglês, Mov10 RISC Complex RNA Helicase), CDKN1A (do inglês, Cyclin Dependent Kinase Inhibitor 1A) como hubs no primeiro dia após a imunização (Figura 9). 
Figura 9. Rede de interação proteína-proteína construída com os DEGs do dia 1.



A rede foi construída a partir da lista dos genes sobre-regulados no primeiro dia após a imunização quando comparados ao tempo inicial. Foi utilizado o parâmetro minimum network, que constrói a rede a partir do número mínimo de genes. As linhas cinzas representam as conexões entre os genes e cada círculo representa um gene. Quanto maior o círculo, maior o número de conexões do mesmo com os demais genes (Degree). As cores dos nós representam o graus, os números de conexões do maior para o menor são representadas pelas cores: azul escuro, azul claro, verde, amarelo claro, amarelo escuro, laranja e vermelho. 


\subsubsection{Análise de redes de Coexpressão}

Módulos gênicos, contendo genes com padrões de expressão semelhantes (isto é, coexpressos), foram identificados usando o pacote CEMiTool (RUSSO et al., 2018). As associações entre diferentes tipos de dados, e módulos gênicos foram representadas como redes. Dados de interação proteína-proteína obtidas a partir de bases de dados Interact foram integradas para ligar genes associados à resposta imune.

As amostras foram divididas em quatro grupos, sendo eles: voluntários vacinados com a dose de $1 \times 10^{7}$ (grupo 1), $5 \times 10^{7}$ (grupo 2), placebo (grupo 3) e todas as doses (grupo 4) para rodar o CEMiTool. Os resultados mostrados abaixo correspondem às análises realizadas com o grupo 4, ou seja, todos os voluntários imunizados (grupo 1 e 2) e o grupo 3 (placebo), quando comparados ao controle (Dia 0 - antes da vacinação).

A partir dos dados de RNA-seq da coorte de Genebra, foram identificados oito módulos de coexpressão gênica, sendo que apenas os módulos 1 (M1) e 7 (M7) apresentaram enriquecimento significativo nas análises de ORA (do inglês, Over Representation Analysis). A Figura 10A mostra o enriquecimento do M1 por ORA, que demonstra sua relação com a resposta imune, e de defesa do hospedeiro. Já a figura 10B representa os dados de interação dos genes coexpressos e as interações proteína-proteína (PPI) no M1. Os genes hubs, ou seja, os que apresentam maior número de interações estão identificados. Os genes com maior interação PPI foram FBXO6 e UBC com um network degree próximo a 600. O M7 foi enriquecido para vias relacionadas à coagulação sanguínea, homeostasis, regulação de fluidos corpóreos e resposta à cicatrização. Resultados de interação destacaram o gene VCL (do inglês, Vinculin) como maior hub a partir dos dados de interação. 
Figura 10. Análise de coexpressão de voluntários imunizados com a vacina VSV-ZEBOV e voluntários placebos.

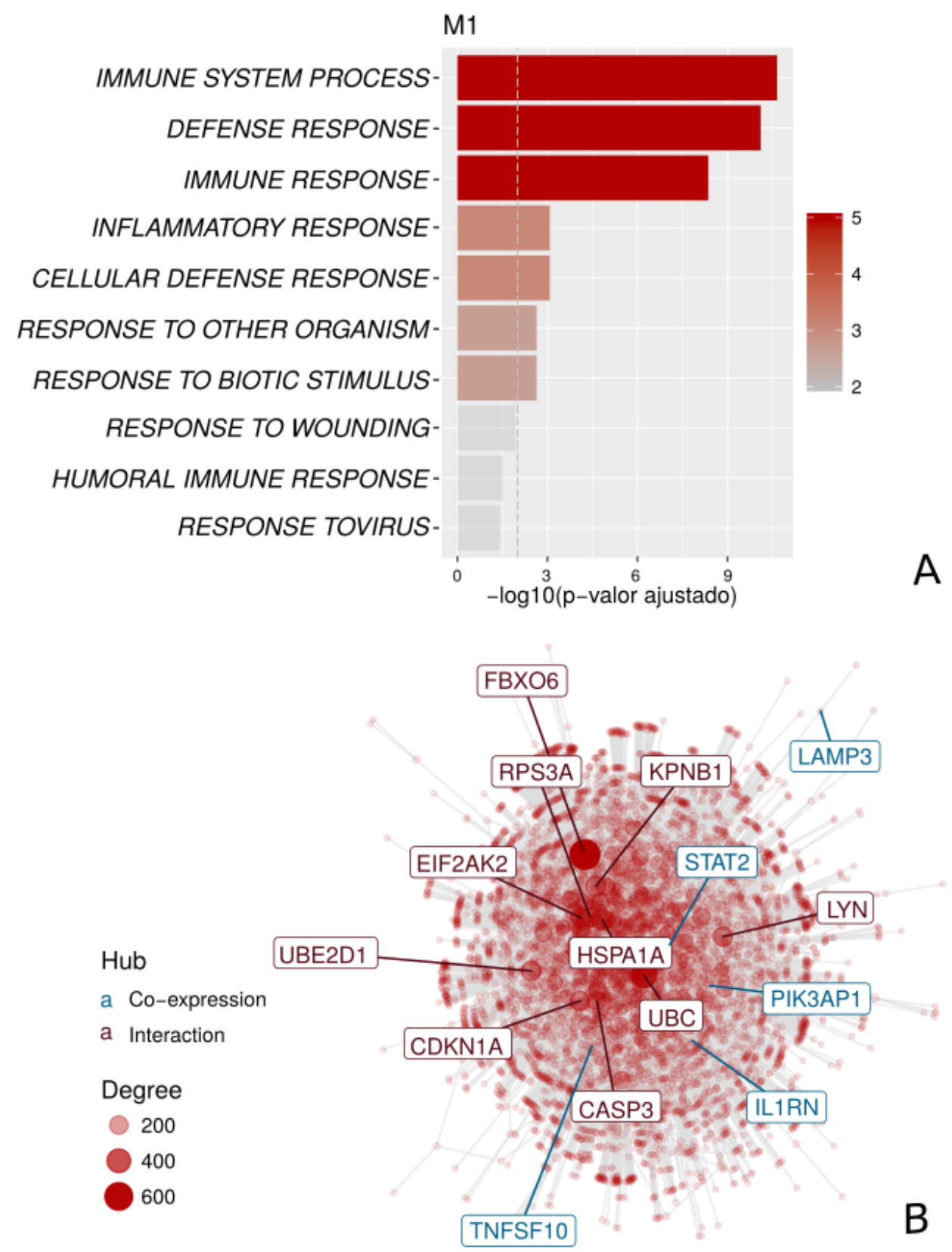

Resultados da análise de representação de módulos M1 usando conjuntos de genes do banco de dados Reactome Pathway para a coorte de Genebra a partir de dados de RNA-seq. Os resultados foram obtidos através de dados de voluntários imunizados com a vacina VSV-ZEBOV e voluntários placebos, considerando dia 0 como controle. (A) O gráfico de barras mostra o valor $P$ ajustado - $\log 10$ do enriquecimento entre os genes em módulos e conjuntos de genes do banco de dados Reactome Pathway. As vias foram ordenadas por significância conforme indicado no eixo $\mathrm{x}$. A linha cinza tracejada vertical indica um valor $P$ ajustado de 0,01. (B) Gráfico de interação para M1, com nós de genes destacados. Os nós representam os genes de M1 mais os genes adicionados por informações de interação proteína-proteína. Os genes são conectados por coexpressão e / ou interação proteína-proteína. A rede de genes do módulo M1 para os genes mais conectados (hubs) são rotulados e coloridos de acordo com sua "origem": se originalmente presentes no 
módulo CEMiTool, eles são coloridos em azul; se inseridos a partir das interações, eles são coloridos em vermelho. O tamanho do nó é proporcional ao seu grau (número de conexões).

\subsection{Dados de dcRT-MLPA}

\subsubsection{Pré processamento de dados de dcRT-MLPA}

Como descrito no item 3.2 os dados de dcRT-MLPA foram obtidos para as coortes de Genebra, Kilifi, Gabão e EUA. A extração do RNA, processamento dos dados de MLPA e remoção de outliers foram realizados pelos nossos colaboradores da Academisch Ziekenhuis Leiden (LUMC - Holanda).

\subsubsection{Avaliação da variabilidade dos dados}

A avaliação da variabilidade dos dados é uma etapa crucial para garantir a qualidade das demais análises. Deste modo, análises exploratórias foram realizadas para entender como os dados se apresentavam em cada uma das coortes estudadas. Para tal, cada uma das coortes foi submetida a análises exploratórias, e normalização de maneira individual, quando estas envolviam comparações entre tempos de coleta.

Em contrapartida, para análises preditivas, as quais envolviam dados de voluntários antes da imunização, avaliamos o efeito de diferentes variáveis na variância dos dados. A análise de PVCA com os mesmos dados pré-vacinação, atribuiu mais de $92 \%$ da variância à coorte e menos de $8 \%$ ao resíduo (Figura 11).

Figura 11. PVCA dados de MLPA das coortes de Genebra, Kilifi, Gabão e USA.

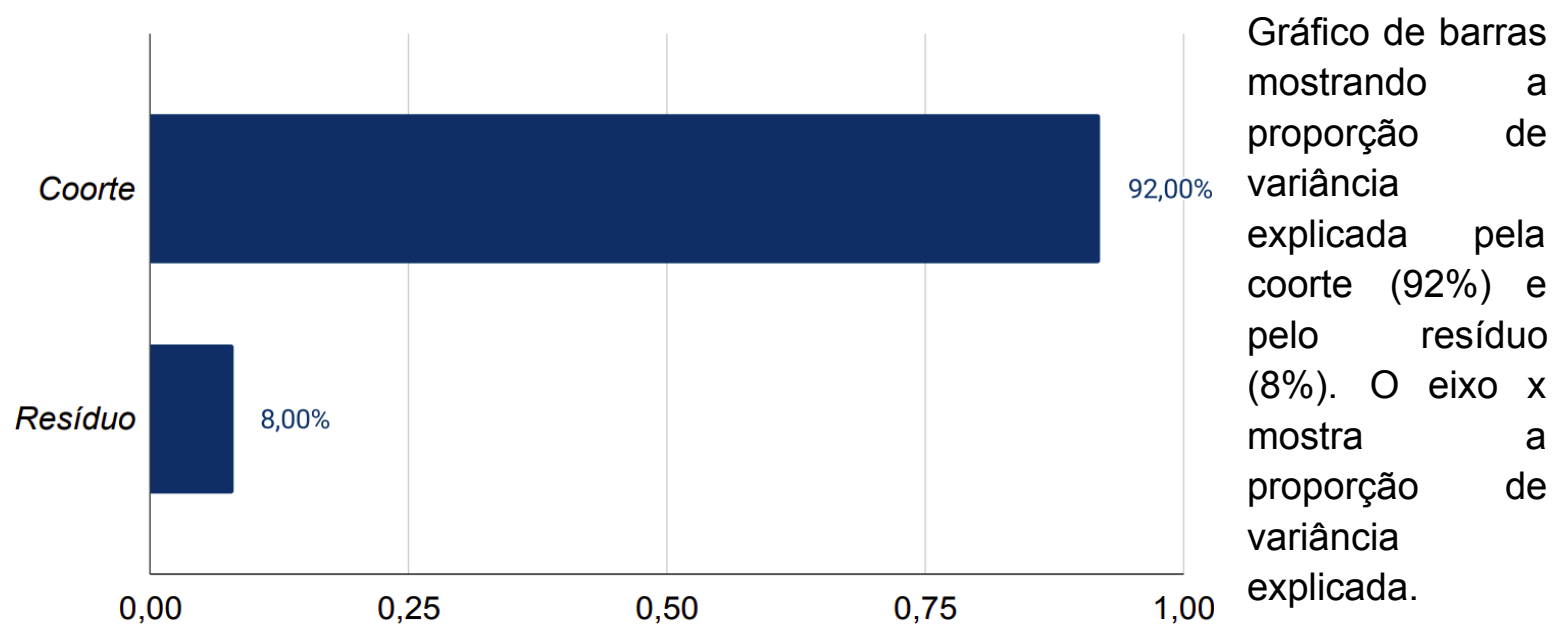


A partir dos resultados de PVCA e PCA (Figura 12A), é possível notar a influência da coorte na dispersão das amostras, mostrando que a natureza étnica, e/ou método de obtenção das amostras tem grande impacto na variância.

Como o objetivo da nossa análise preditiva era encontrar genes que classificassem eventos adversos, considerando a contribuição biológica dos mesmos, decidimos remover o efeito de lote da dose e da coorte. A dispersão das amostras de voluntários antes da imunização, a partir de dados de expressão bruto, é ilustrada na Figura 12A, enquanto a dispersão a partir dos dados após a remoção do efeito de lote é mostrada na Figura 12B.

Figura 12. Impacto das coortes nos perfis de expressão gênica antes da vacinação com rVSV-ZEBOV para os dados antes e depois da remoção do efeito de lote.

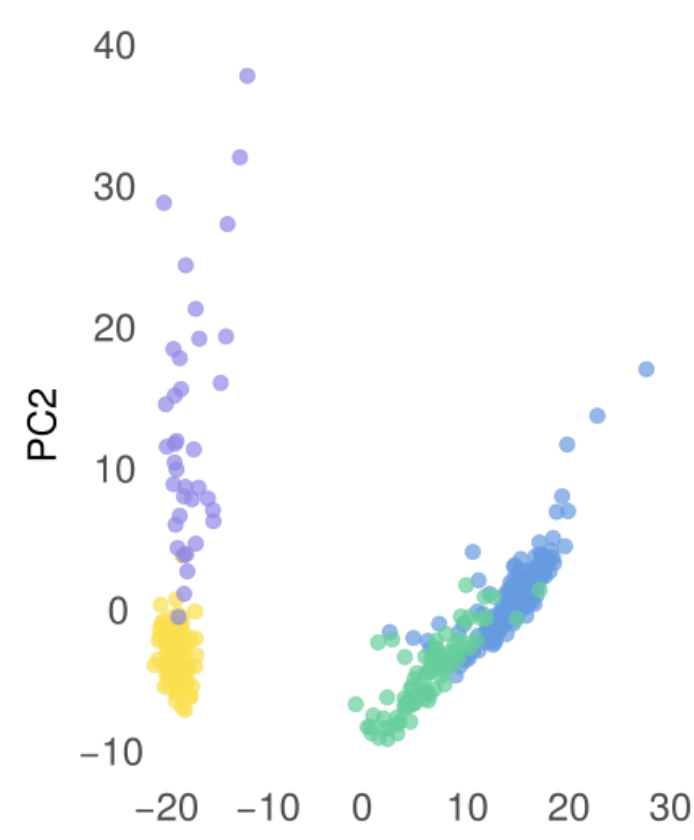

Coorte

- Gabão

Genebra

- Kilifi

EUA

A

PC1

B

PC1

Análise de PCA dos dados de MLPA de voluntários antes da imunização. As cores representam as coortes avaliadas, sendo elas Genebra (amarelo), Kilifi (roxo), Gabão (verde) e EUA (azul). O eixo $x$ representa a dispersão das amostras no componente principal $1(\mathrm{PC} 1)$ enquanto o eixo $\mathrm{Y}$ representa a dispersão das amostras no componente principal 2 ( $(\mathrm{PC} 2)$. Na figura $\mathrm{A}$ a dispersão é avaliada nos dados brutos, enquanto que na figura B esta dispersão é avaliada após a remoção do efeito da coorte e da dose nos dados tratados. 


\subsubsection{Análise de expressão diferencial}

A identificação dos genes diferencialmente expressos em cada tempo de coleta em relação à expressão antes da imunização foi realizada em cada uma das coortes com o teste de Mann-Whitney não pareado, com correção de Benjamini-Hochberg. Sendo definido DEGs os genes com p-valor abaixo de um limiar $(p<0.05)$ e Log2 (fold-change) absoluto acima de um limiar ( $F C>1.5)$. A quantidade de DEGs obtidos em cada comparação por coorte são mostrados na Figura 13. O maior número de DEGs foi obtido a partir da comparação do dia $1 \mathrm{com}$ o tempo inicial (dia 0). Foram obtidos 39 e 28 genes sobre-regulados, e quatro e cinco genes sub-regulados nas coortes de Genebra e EUA, respectivamente. Para a coorte de Gabão, foram obtidos 36 genes sobre-regulados e 3 sub-regulados no tempo 7 , valores comparáveis ao tempo 1 nas demais coortes.

Figura 13. Número de Genes Diferencialmente expressos por coorte e tempo de comparação obtidos a partir de dados de dcRT-MLPA.

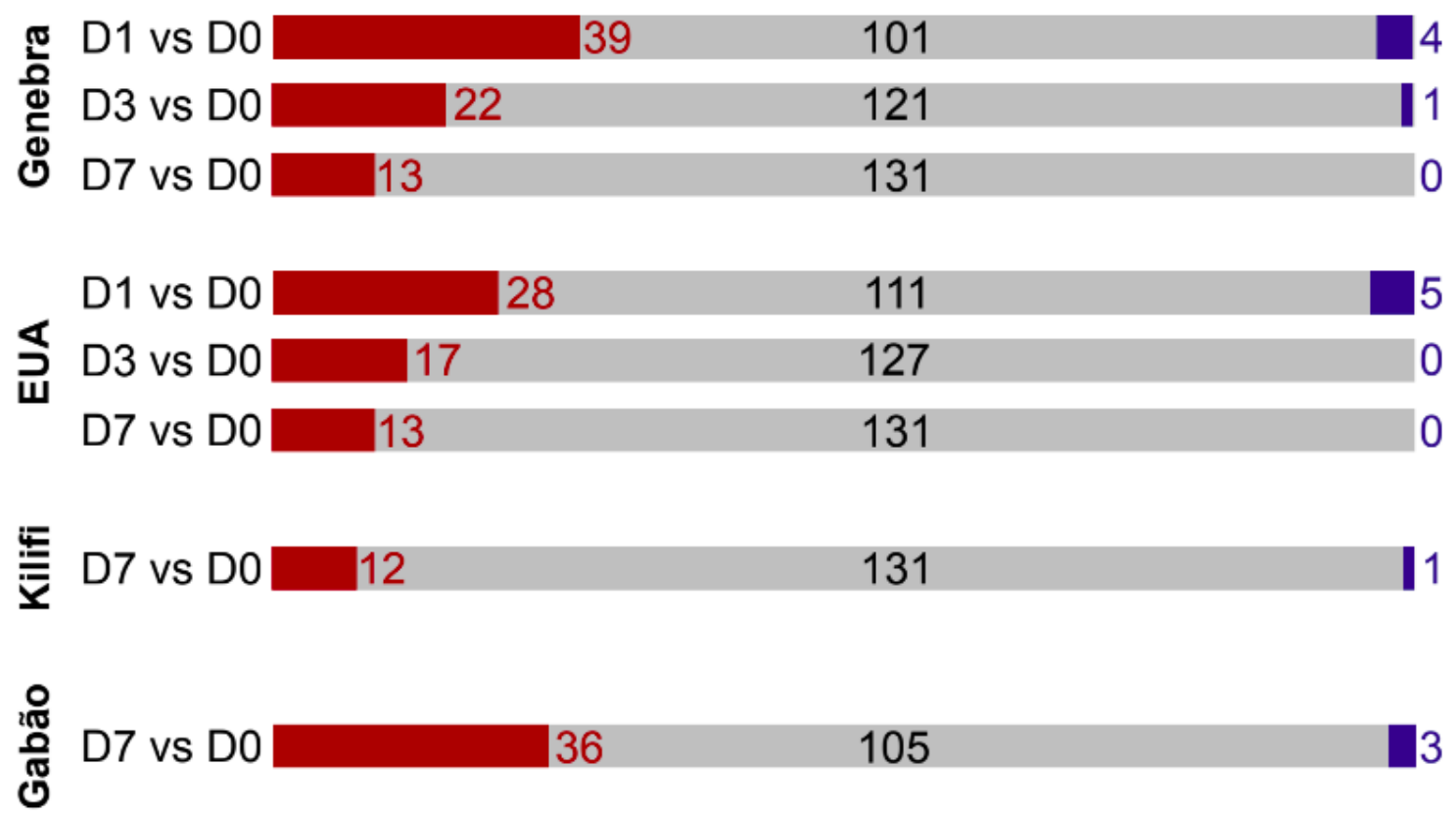

A quantidade de genes sobre-expressos é representada pelas porções em vermelho e a quantidade de genes sub-expressos é representada pelas porções em azul, a porção cinza representa a quantidade de genes com expressão normal quando comparados à expressão no dia 0 (D0, tempo inicial). 
Apenas no dia 7 foram coletadas amostras em todas as coortes em estudo. Foi realizado um Diagrama de Venn (Figura 14) para encontrar os DEGs consistentes em todas as coortes.

\section{Figura 14. Número de DEGs compartilhados entre as quatro coortes no dia 7 após a vacinação.}

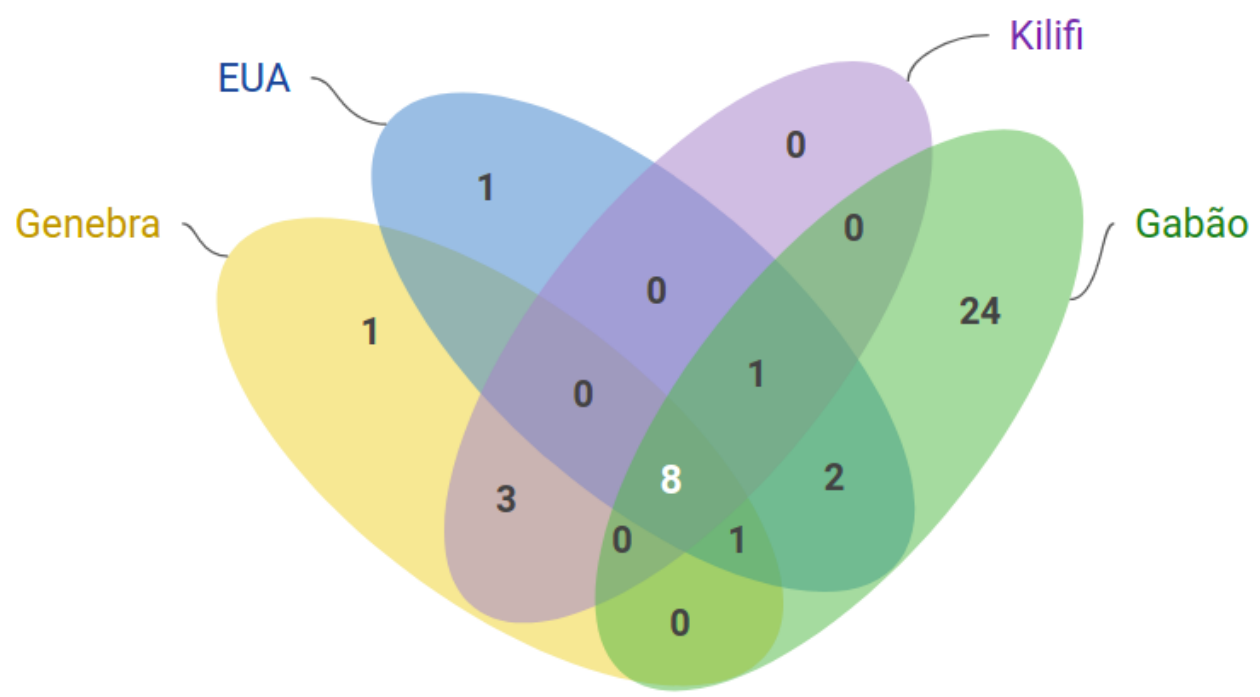

Diagrama de Venn que ilustra a sobreposição de genes diferencialmente expressos entre as coortes Genebra (amarelo), kilifi (roxo), Gabão (verde) e EUA (azul) no dia 7 vs o dia 0 em voluntários imunizados. O número em branco representa a quantidade de genes compartilhados entre todas as coortes. Os números em preto representam a quantidade de genes diferencialmente expressos que não são compartilhados por todas as coortes, mas por apenas uma ou algumas delas.

Oito DEGs do dia 7, todos sobre-expessos, são compartilhados em todas as coortes, sendo eles, IFI6 (do inglês, Interferon Alpha Inducible Protein 6), IFI44 (do inglês, Interferon Alpha Inducible Protein 44), IFI44L (do inglês, Interferon Induced Protein 44 Like), IFIT2 (do inglês, Interferon Induced Protein With Tetratricopeptide Repeats 2), IFIT3 (do inglês, Interferon Induced Protein With Tetratricopeptide Repeats 3), IFITM3 (do inglês, Interferon Induced Transmembrane Protein 3), OAS2 (do inglês, 2'-5'-oligoadenylate synthetase 2) e OAS3 (do inglês, 2'-5'-Oligoadenylate Synthetase 3). Para conferir se esses genes participavam de alguma via de regulação gênica, submetemos essa lista à ferramenta online Enrichr (https://maayanlab.cloud/Enrichr/) (CHEN et al., 2013). Os resultados a partir do banco de dados Reactome (FABREGAT et al., 2018) demonstram o enriquecimento desses genes para vias de sinalização de interferon e citocinas (Figura 15). Ambas 
vias estão relacionadas à resposta imune inata em resposta à infecção viral. Estes resultados mostram que ambos os dias 1 e 7 apresentam a mesma resposta com variação apenas de intensidade.

Figura 15. Análise de enriquecimento a partir dos 8 DEGs compartilhados entre todas as coortes no dia 7.

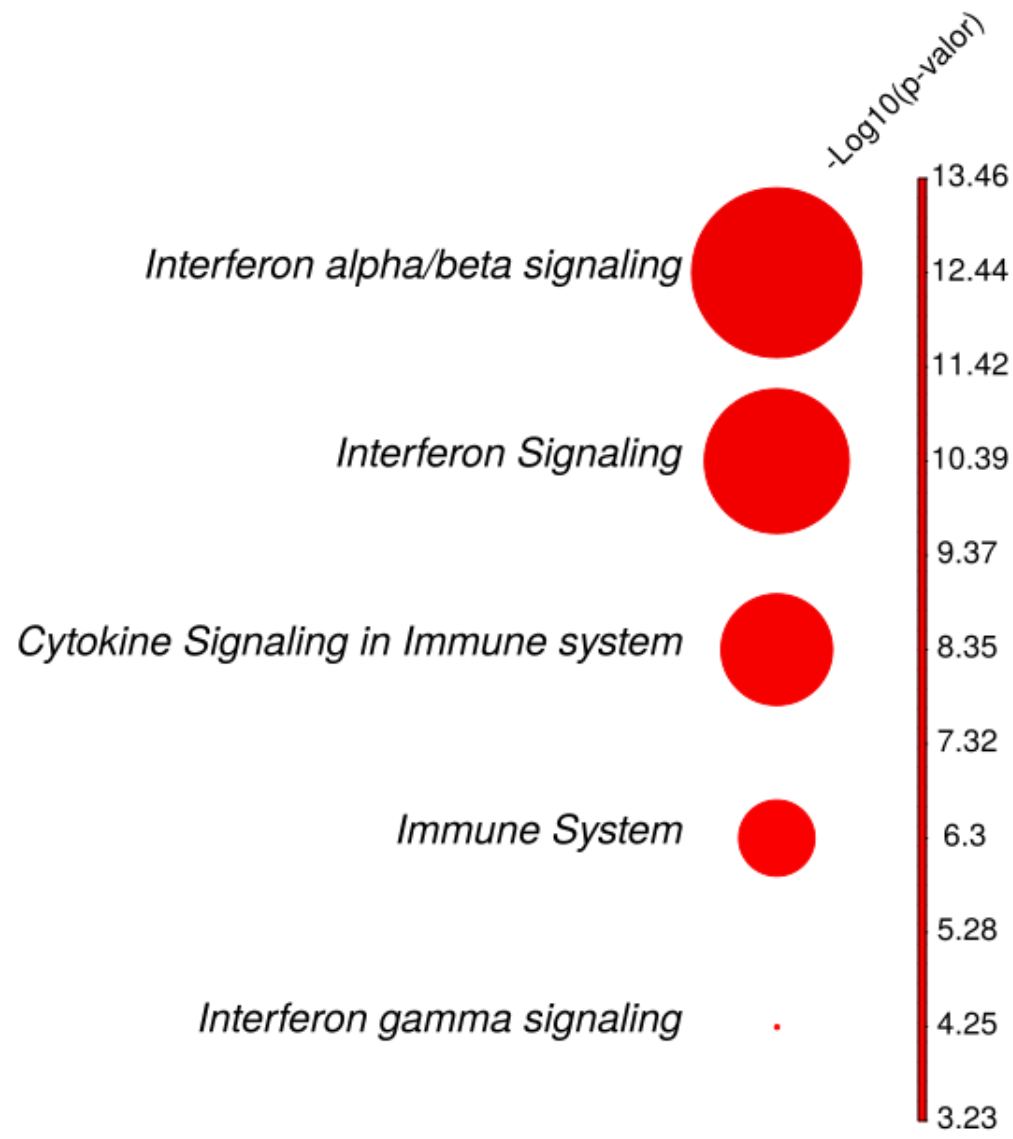

Os oito genes identificados como DEGs no dia $7 \mathrm{em}$ todas as coortes em estudo foram submetidos ao enriquecimento de vias com o banco de dados Reactome, a partir da ferramenta Enrichr. As vias com $\mathrm{p}$-valor < 0.05 foram selecionadas e transformadas - $\log 10$ (p-valor) para que o enriquecimento das vias fosse melhor visualizado. $O$ tamanho do círculo é diretamente proporcional ao valor de significância dos genes para a via.

\subsubsection{Análise de Redes de Coexpressão}

Foram feitas análises de redes de coexpressão a partir dos dados de MLPA obtidos nas coortes de Genebra, Kilifi, Gabão e EUA, como descrito para os dados de RNA-seq com a coorte de Genebra. Todos os tempos disponíveis para as análises, descritos no item 3.2, foram utilizados nestas análises. Na coorte de Genebra foi possível identificar apenas 1 módulo de coexpressão (Figura 16). Este 
módulo teve enriquecimento positivo para vias do sistema imune, resposta a organismos invasores, e produção de citocinas (Figura 16A). $\mathrm{Na}$ análise de interação proteína-proteína dos genes do $\mathrm{M} 1$, o maior hub na rede do Interactoma foi o gene LYN (do inglês, Tyrosine-Protein Kinase Lyn), que codifica a proteína tirosina quinase (Figura 16B).

Figura 16. Análise de coexpressão com dados de dcRT-MLPA da coorte de Genebra.
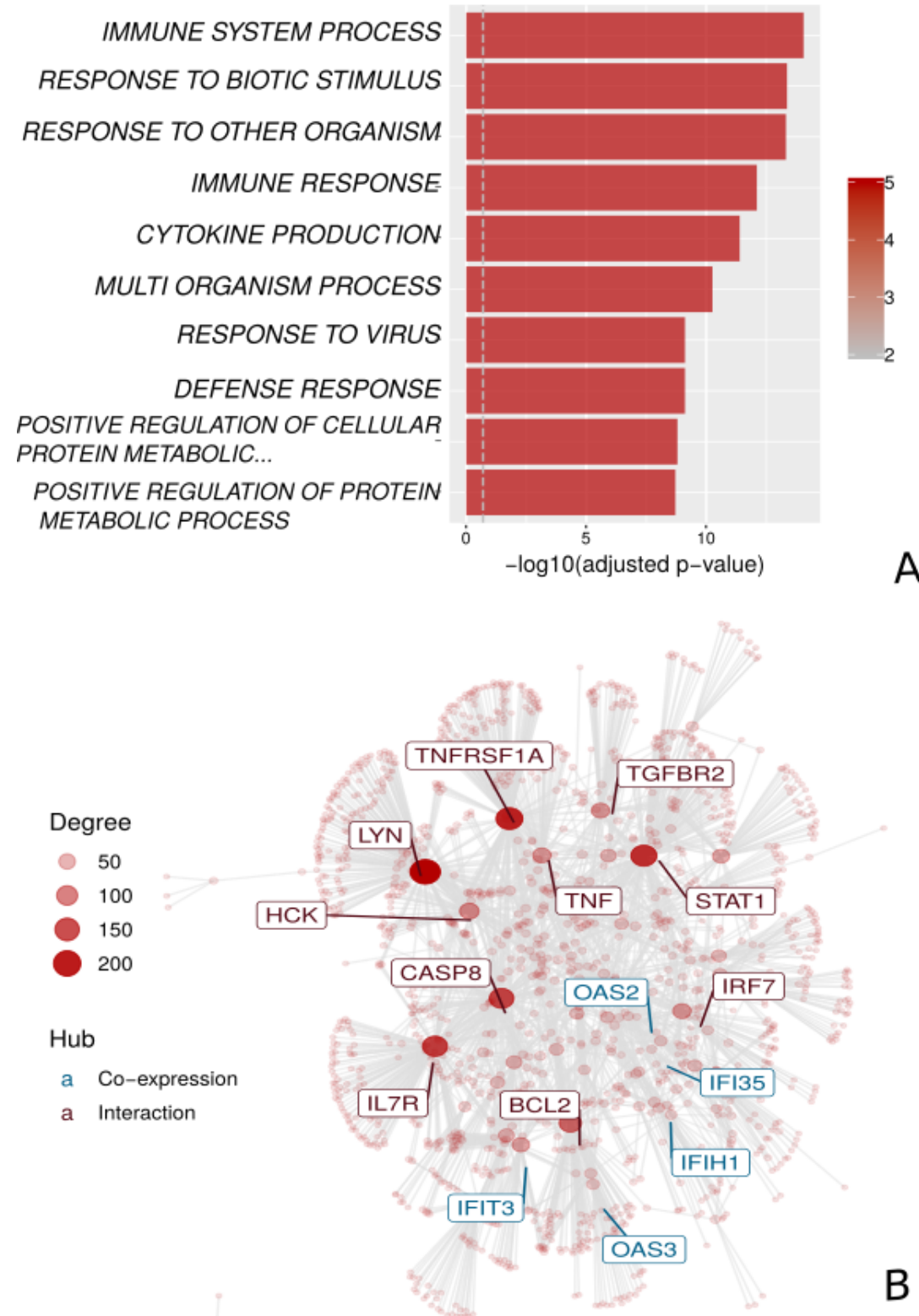

Resultados da análise de representação de módulos $M$ usando conjuntos de genes do banco de dados Reactome Pathway para a coorte de Genebra. Os resultados foram obtidos 
através de dados de voluntários imunizados com a vacina VSV-ZEBOV e voluntários placebos, considerando dia 0 como controle. (A) $O$ gráfico de barras mostra o valor $P$ ajustado - $\log 10$ do enriquecimento entre os genes em módulos e conjuntos de genes do banco de dados Reactome Pathway. As vias foram ordenadas por significância conforme indicado no eixo $x$ e as 10 mais significativas foram selecionadas. A linha cinza tracejada vertical indica um valor P ajustado de 0,01. (B) Gráfico de interação para M1, com nós de genes destacados. Os nós representam os genes de M1 mais os genes adicionados por informações de interação proteína-proteína. Os genes são conectados por coexpressão e / ou interação proteína-proteína. A rede de genes do módulo M1 para os genes mais conectados (hubs) são rotulados e coloridos de acordo com sua "origem": se originalmente presentes no módulo CEMiTool, eles são coloridos em azul; se inseridos a partir das interações, eles são coloridos em vermelho, e são originários de ambos, eles são coloridos em verde. O tamanho do nó é proporcional ao seu grau (número de conexões).

Do mesmo modo que em Genebra, nos dados de Kilifi foi encontrado apenas um módulo de expressão (Figura 17), com o mesmo enriquecimento (Figura 17A) e também com o gene $L Y N$ como o maior hub (Figura 17B).

\section{Figura 17. Análise de coexpressão com dados de dcRT-MLPA da coorte de} Kilifi.

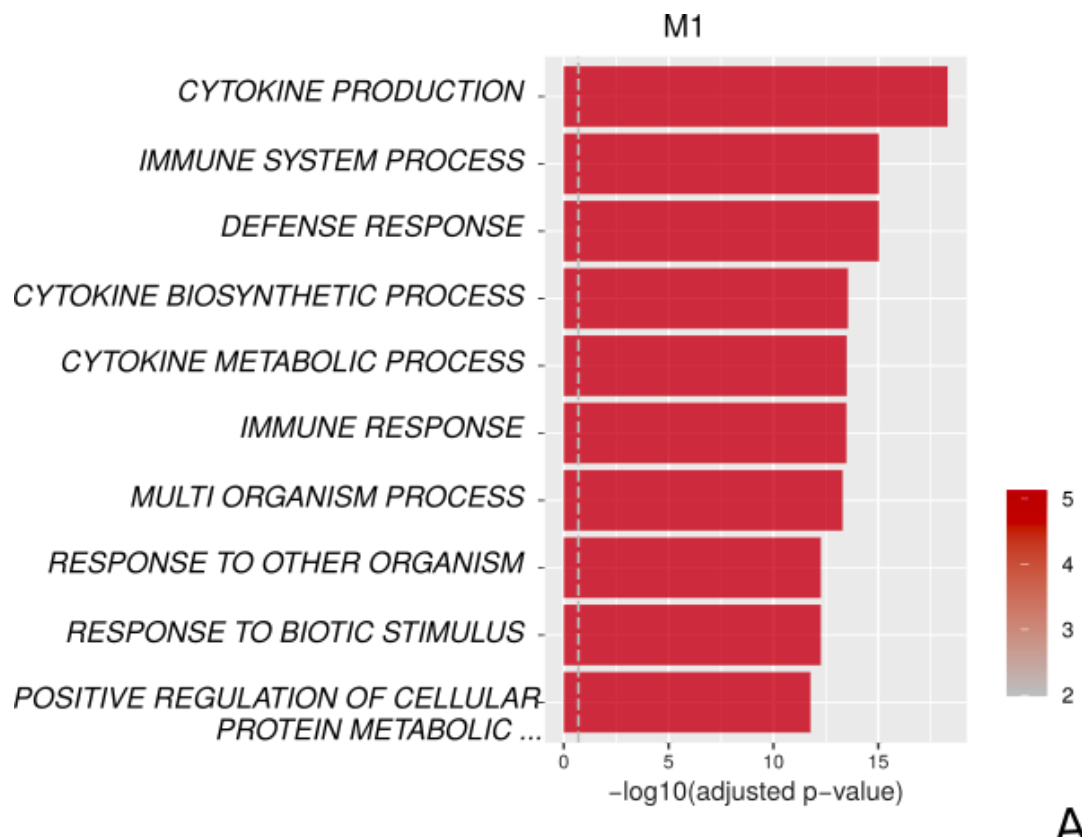




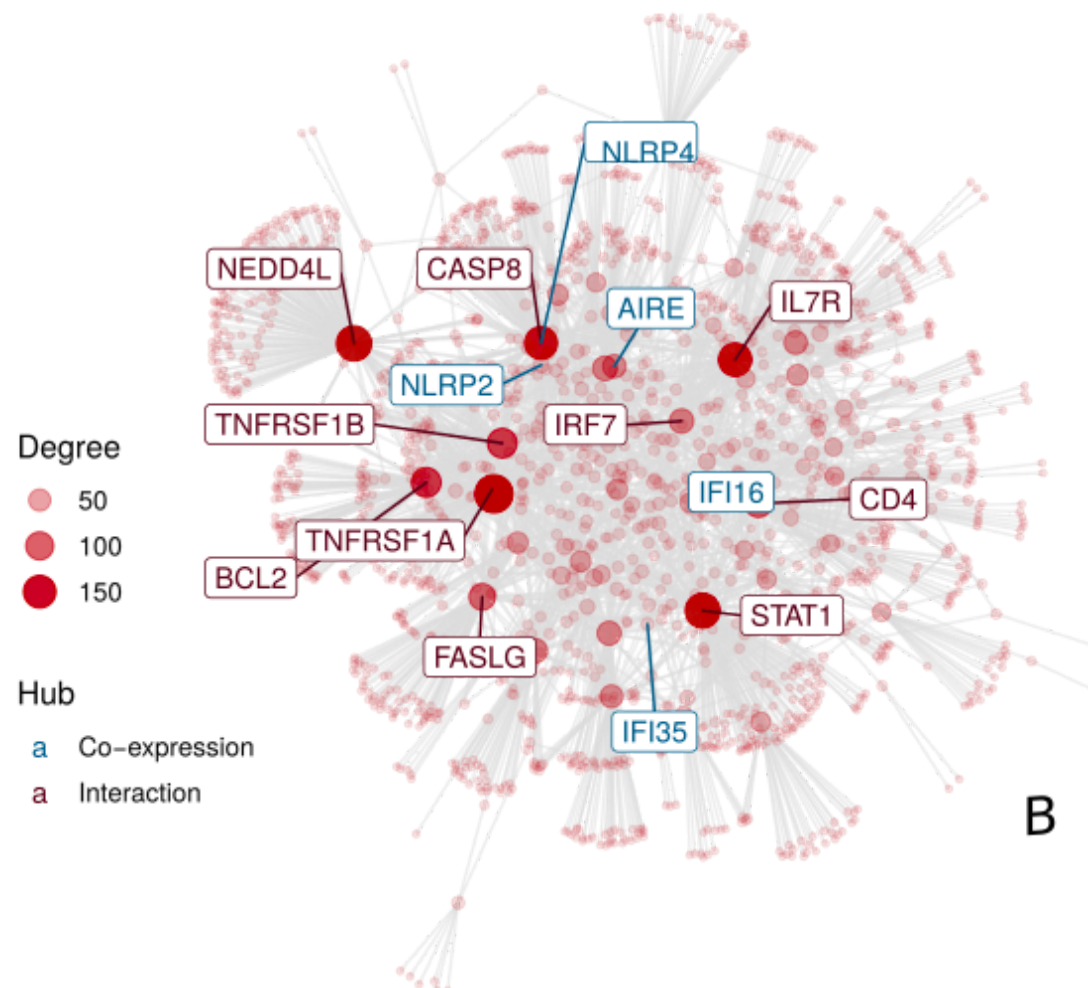

São mostrados os resultados da análise de representação de módulos $\mathrm{M}$ usando conjuntos de genes do banco de dados Reactome Pathway para a coorte de Kilifi. Os resultados foram obtidos através de dados de voluntários imunizados com a vacina VSV-ZEBOV e voluntários placebos, considerando dia 0 como controle. (A) $\mathrm{O}$ gráfico de barras mostra 0 valor $\mathrm{P}$ ajustado - $\log 10$ do enriquecimento entre os genes em módulos e conjuntos de genes do banco de dados Reactome Pathway. As vias foram ordenadas por significância conforme indicado no eixo $\mathrm{x}$ e as 10 mais significativas foram selecionadas. A linha cinza tracejada vertical indica um valor $P$ ajustado de 0,01 . (B) Gráfico de interação para $M 1$, com nós de genes destacados. Os nós representam os genes de M1 mais os genes adicionados por informações de interação proteína-proteína. Os genes são conectados por coexpressão e / ou interação proteína-proteína. A rede de genes do módulo M1 para os genes mais conectados (hubs) são rotulados e coloridos de acordo com sua "origem": se originalmente presentes no módulo CEMiTool, eles são coloridos em azul; se inseridos a partir das interações, eles são coloridos em vermelho, e são originários de ambos, eles são coloridos em verde. O tamanho do nó é proporcional ao seu grau (número de conexões).

Com a coorte Gabão foram encontrados dois módulos de coexpressão (Figura 18). O primeiro, M1, apresentou o mesmo enriquecimento das outras coortes. Enquanto o módulo M2 foi enriquecido para o sistema de resposta ao vírus (Figura 18A). No primeiro (M1) o gene TNFRSF1A (do inglês, TNF Receptor Superfamily Member $1 A$ ) foi o principal hub (Figura 18B) e no segundo (M2) o gene LYN (Figura 18C). 
Figura 18. Análise de coexpressão com dados de dcRT-MLPA da coorte de Gabão.

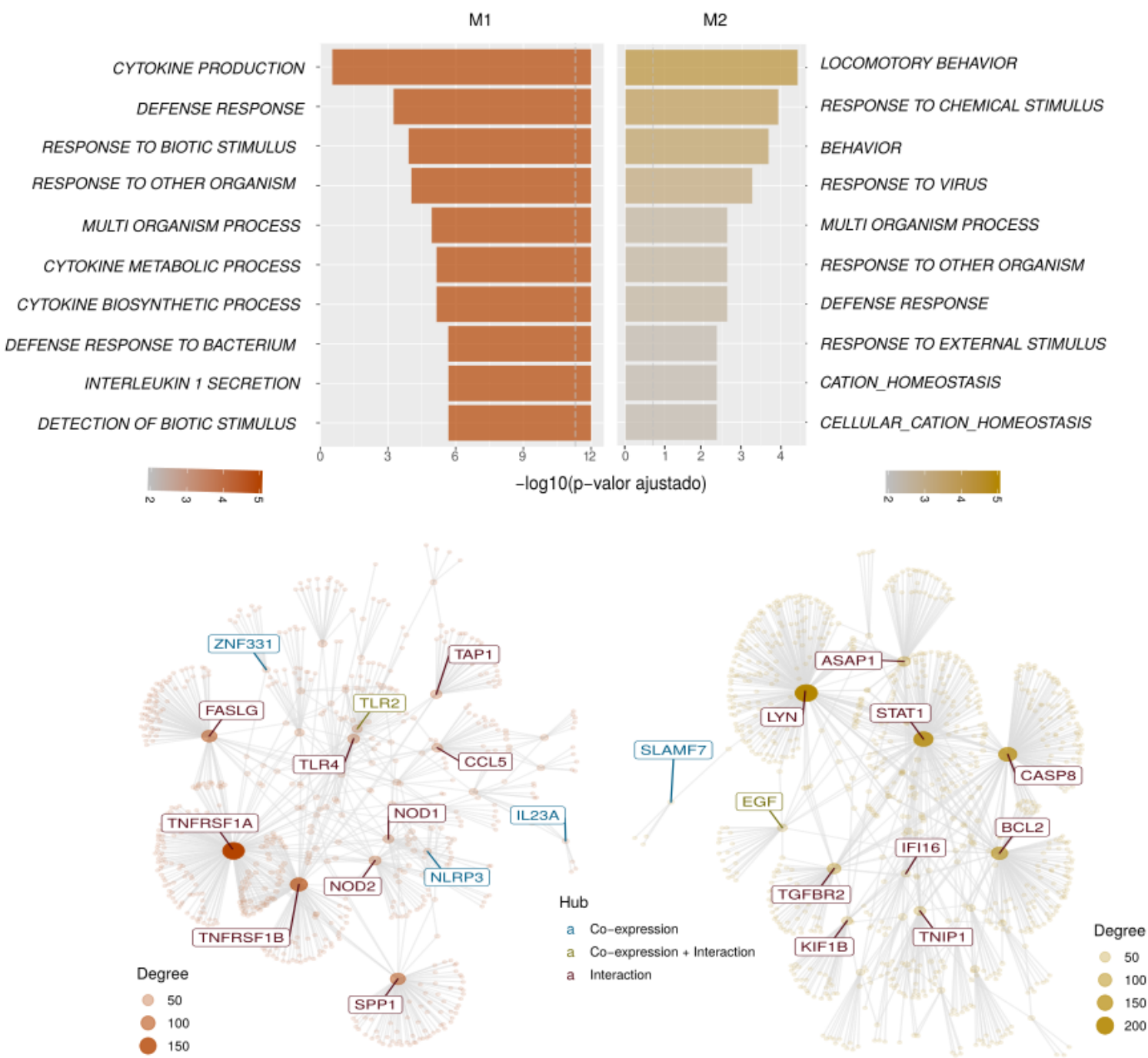

São mostrados os resultados da análise de representação de módulos $M$ usando conjuntos de genes do banco de dados Reactome Pathway para a coorte de Gabão. Os resultados foram obtidos através de dados de voluntários imunizados com a vacina VSV-ZEBOV e voluntários placebos, considerando dia 0 como controle. (A) Os gráficos de barras mostram o valor $P$ ajustado - $\log 10$ do enriquecimento entre os genes em módulos e conjuntos de genes do banco de dados Reactome Pathway. As vias foram ordenadas por significância conforme indicado no eixo $\mathrm{x}$ e as 10 mais significativas foram selecionadas. A linha cinza tracejada vertical indica um valor $P$ ajustado de 0,01 . (B) Gráficos de interação para M1 e M2, com nós de genes destacados. Os nós representam os genes de M1 (a direita) e M2 (a esquerda) mais os genes adicionados à rede por informações de interação proteína-proteína. Os genes são conectados por coexpressão e / ou interação proteína-proteína. As redes de genes dos módulos M1 e M2 para os genes mais conectados (hubs) são rotulados e coloridos de acordo com sua "origem": se originalmente presentes no módulo CEMiTool, eles são coloridos em azul; se inseridos a partir das interações, eles são coloridos em vermelho, e são originários de ambos, eles são coloridos em verde. O tamanho do nó é proporcional ao seu grau (número de conexões). 
A partir da coorte dos EUA foi encontrado um módulo de coexpressão (Figura 19). O M1, apresentou o mesmo enriquecimento das outras coortes. O gene NEDD4L apareceu como o principal hub tanto de expressão como interação, e os genes TNFRSF1A, e LYN, também apareceram como hubs importantes (Figura 19B).

Figura 19. Análise de coexpressão com dados de dcRT-MLPA da coorte dos EUA.

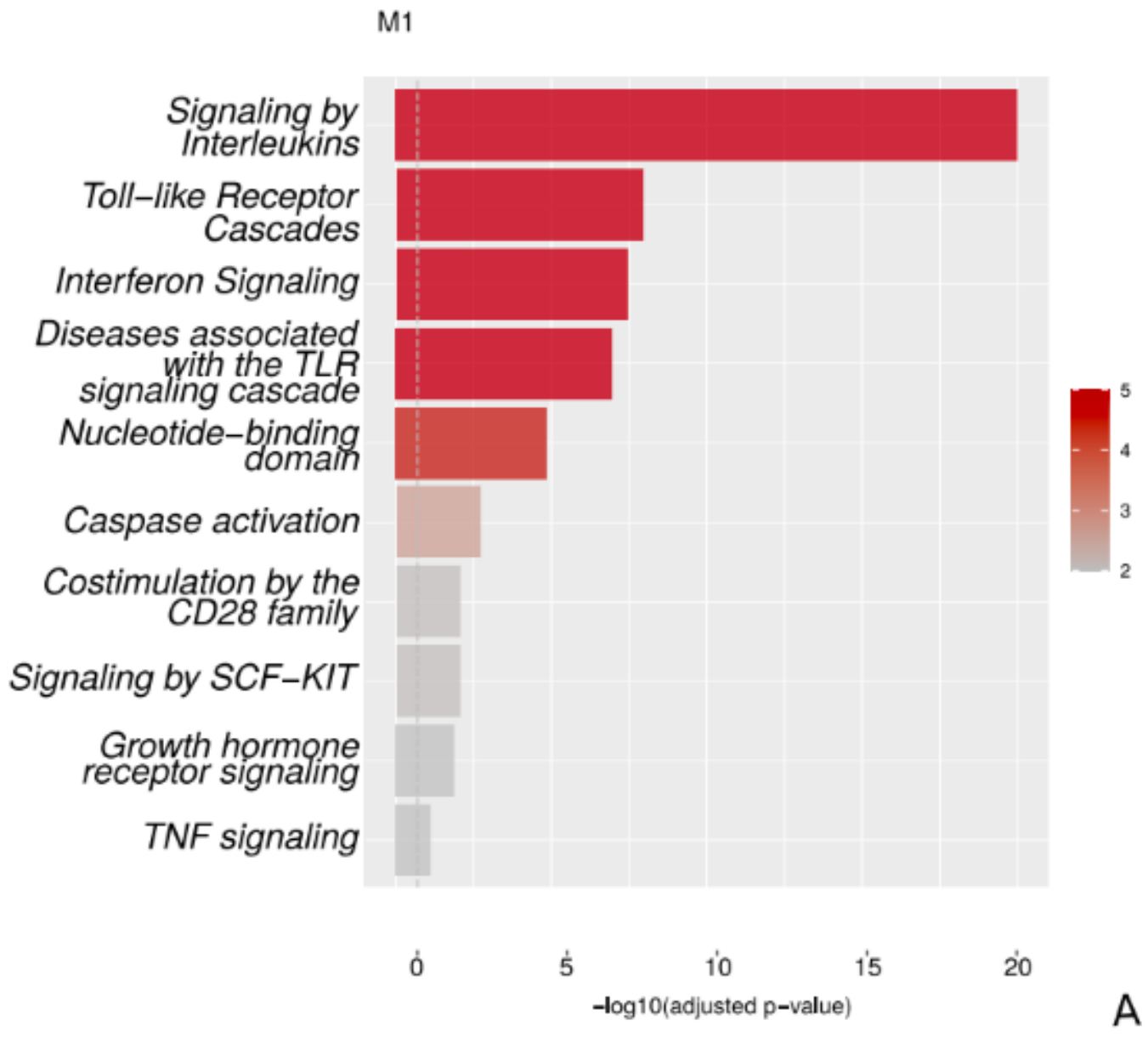




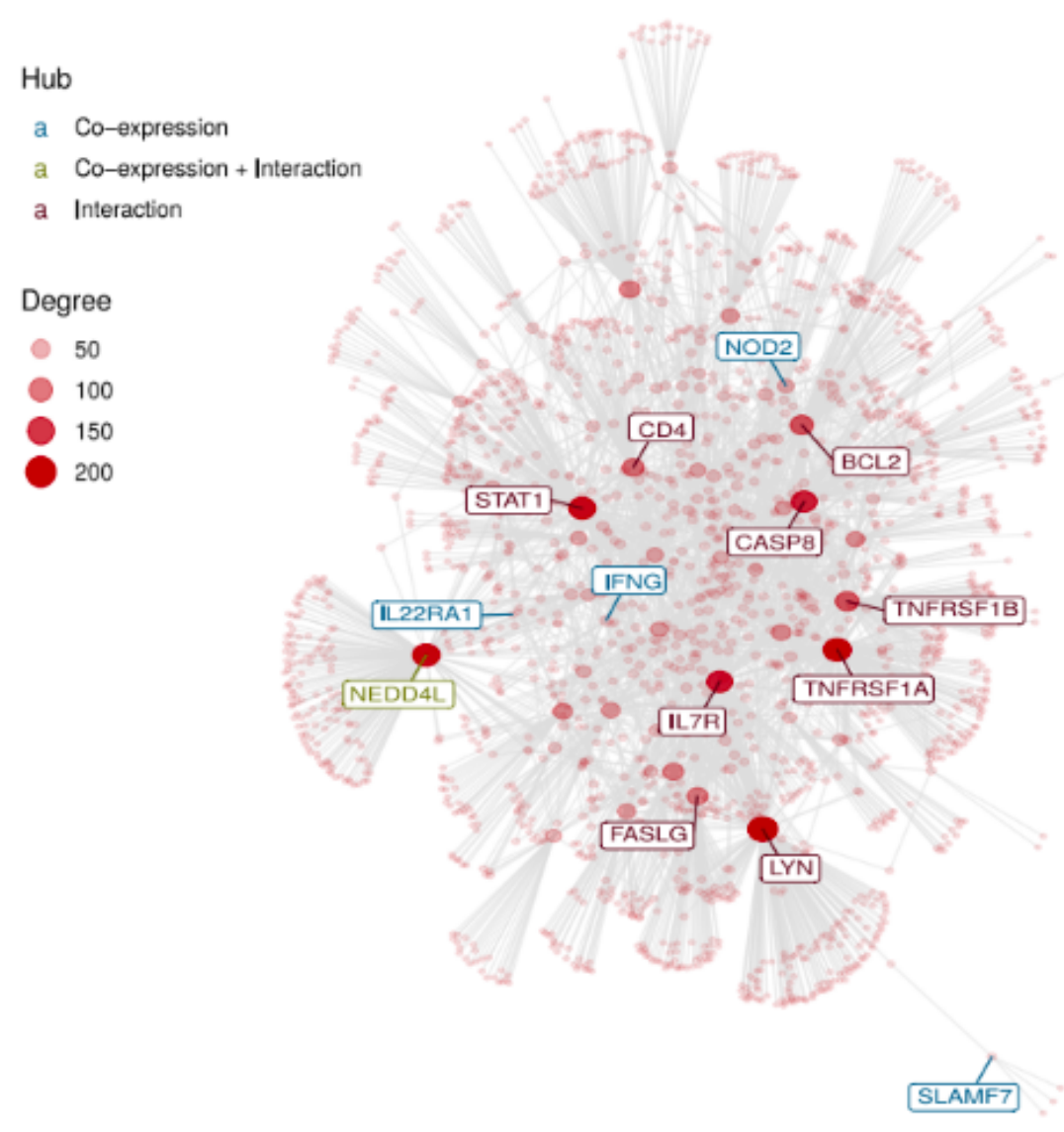

São mostrados os resultados da análise de representação de módulos $M$ usando conjuntos de genes do banco de dados Reactome Pathway para a coorte dos EUA. Os resultados foram obtidos através de dados de voluntários imunizados com a vacina VSV-ZEBOV e voluntários placebos, considerando dia 0 como controle. (A) O gráfico de barras mostra o valor $\mathrm{P}$ ajustado - $\log 10$ do enriquecimento entre os genes em módulos e conjuntos de genes do banco de dados Reactome Pathway. As vias foram ordenadas por significância conforme indicado no eixo $x$ e as 10 mais significativas foram selecionadas. A linha cinza tracejada vertical indica um valor $P$ ajustado de 0,01. (B) Gráfico de interação para M1, com nós de genes destacados. Os nós representam os genes de $\mathrm{M} 1$ mais os genes adicionados por informações de interação proteína-proteína. Os genes são conectados por coexpressão e / ou interação proteína-proteína. A rede de genes do módulo M1 para os genes mais conectados (hubs) são rotulados e coloridos de acordo com sua "origem": se originalmente presentes no módulo CEMiTool, eles são coloridos em azul; se inseridos a partir das interações, eles são coloridos em vermelho, e são originários de ambos, eles são coloridos em verde. O tamanho do nó é proporcional ao seu grau (número de conexões).

\subsection{Integração de dados de expressão gênica e reatogenicidade}

Este trabalho também objetivou compreender a propensão das populações a eventos adversos induzidos pela vacinação com VSV-ZEBOV. Por este motivo, os dados de reatogenicidade foram integrados/pareados com os dados de expressão 
disponíveis. Diferentes abordagens estatísticas foram aplicadas para esta integração, das quais as baseadas em aprendizado de máquina foram as mais promissoras. Para tal, a primeira etapa baseou-se no ranqueamento e seleção genes que melhor classificam os voluntários quanto à ausência ou presença de determinado evento adverso. Diferentes métodos de seleção de atributos foram aplicados nesta etapa. Dado que o desfecho é conhecido e é uma variável categórica, foram aplicadas abordagens de aprendizado de máquina supervisionado de classificação.

\subsubsection{Seleção de atributos}

Diferentes métodos de seleção de atributos foram utilizados a fim de ranquear genes relevantes na classificação de pessoas com de eventos adversos. Esses métodos são baseados em filtro, como por exemplo, Information gain, Gain ratio, Correlation, e baseados em Wrapper como Random Forest, Boruta, RFE.

Muitos dos resultados mostrados neste trabalho foram obtidos a partir da aplicação do algoritmo Random Forest (BREIMAN, 2001), por terem sido mais promissores. Este algoritmo, além de amplamente utilizado em dados biológicos, permite a avaliação da importância dos genes dentro do modelo preditivo. Utilizando este algoritmo fizemos o ranqueamento dos genes quanto a classificação de diferentes eventos adversos para as 4 coortes individualmente e em conjunto. Para tal, nós utilizamos o pacote "randomForest" implementado em $R$, definimos o parâmetro ntree $=1000$ e os demais parâmetros utilizamos os definidos como padrão na função.

Aqui foram mostrados resultados obtidos a partir de todas as coortes conjuntamente. Dados de dcRT-MLPA e de reatogenicidade estavam disponíveis para um total de 343 vacinados. O número de vacinados que relataram a presença ou não de cada um dos eventos adversos é mostrado na figura 20. 
Figura 20. Número de vacinados com presença ou ausência de eventos adversos.

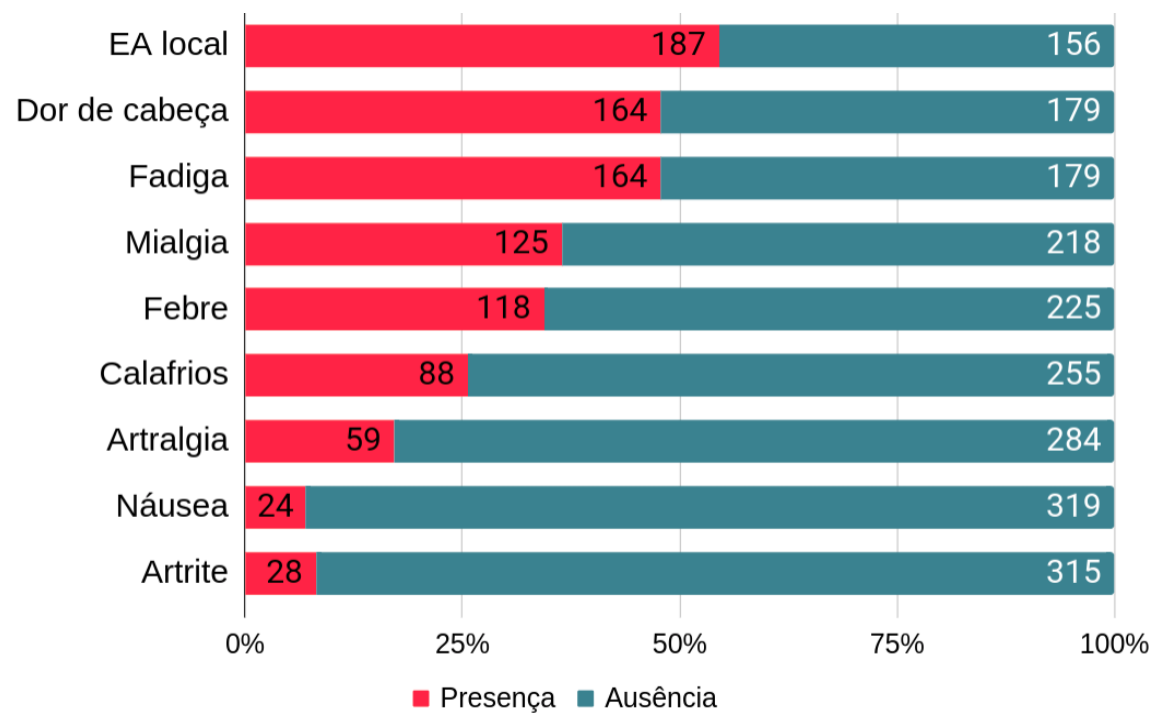
O gráfico mostra a distribuição de vacinados que relataram a presença (em vermelho) e ausência (em azul) de cada um dos eventos adversos. Os valores correspondentes estão descritos em cada uma das barras. 0 eixo $x$ apresenta $a$ porcentagem aproximada de vacinados em cada grupo.

Os resultados de importância obtidos por gene para cada um dos eventos adversos foram somados, e os dez genes com maior valor de soma de importância foram selecionados (Figura 21).

21. Genes ranqueados entre os $10 \mathrm{com}$ maior valor de importância média na classificação de voluntários com eventos adversos à vacinação obtidos com o algoritmo Random Forest.

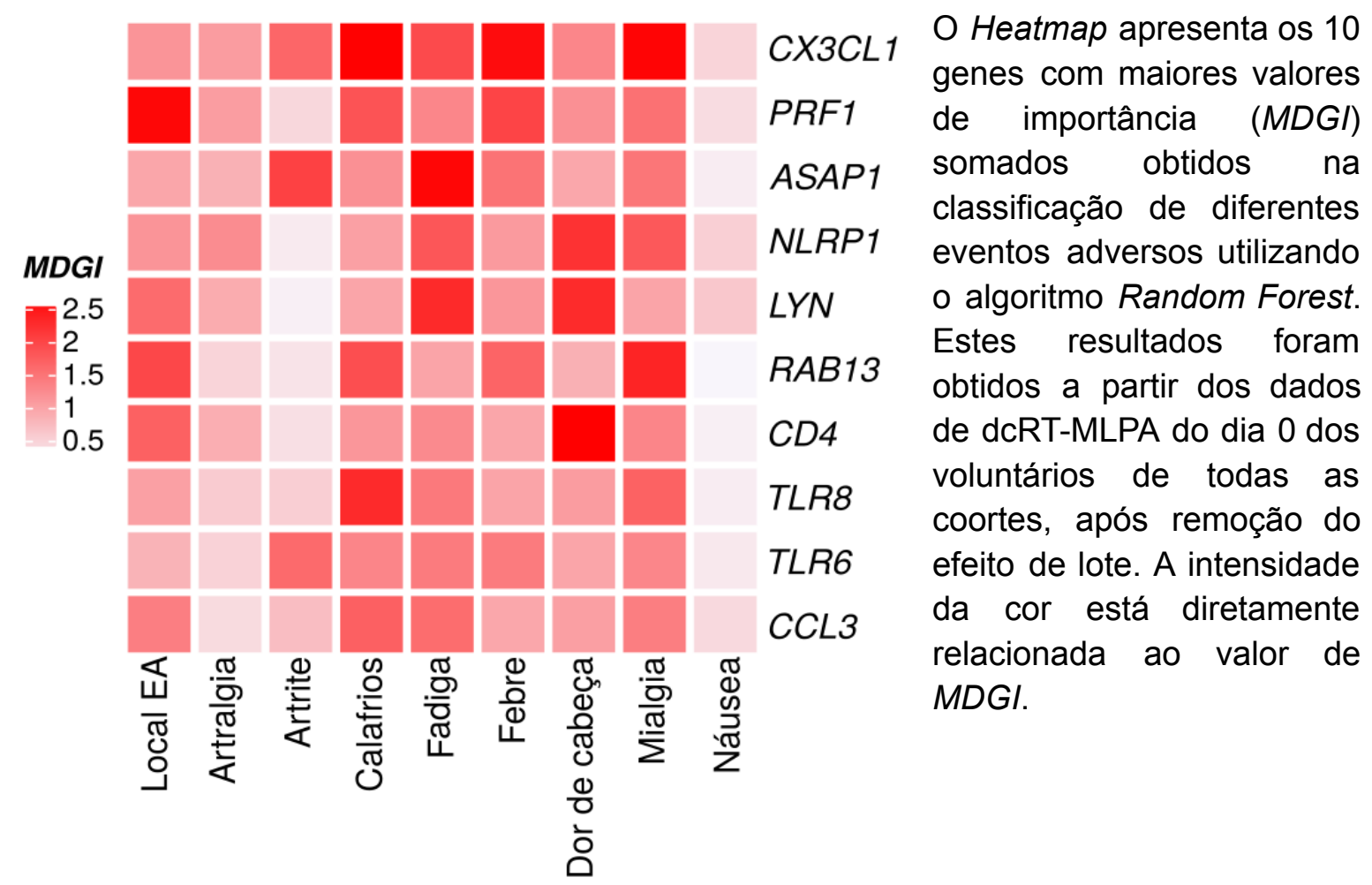


Os mesmos resultados obtidos com Random forest são mostrados na figura 22, onde foram selecionados os genes ranqueados entre os 10 mais importantes em pelo menos 3 eventos adversos. Os genes que foram selecionados como preditores de mais eventos adversos foram os genes CX3CL1 (do inglês, C-X3-C Motif Chemokine Ligand 1), selecionado para 6 eventos adversos (Artralgia, Fadiga, Febre, Artrite,Mialgia e Calafrios). O gene NLRP1 (do inglês, NLR Family Pyrin Domain Containing 1) que foi selecionado entre os 10 melhores preditores de 5 eventos adversos (Artralgia, Fadiga, Náusea, Mialgia e Dor de cabeça). Enquanto isto, o gene PRF1 (do inglês, Perforin 1) foi selecionado para 4 eventos adversos (Artralgia, Febre, Evento adverso local e Calafrios) do mesmo modo que o gene RAB13 (do inglês, RAB13, Member RAS Oncogene Family) (Febre, Evento adverso local, Mialgia e Calafrios). Já os gene IFI44L (do inglês, Interferon Induced Protein 44 Like) foi selecionado para 3 eventos adversos (Náusea, Artrite e Dor de cabeça), assim como os genes GNLY (do inglês, Granulysin) (Artralgia, Náusea, Evento Adverso Local ) e LYN (Fadiga, Náusea, Dor de cabeça).

Figura 22. Rede de conexão de eventos adversos e genes preditores melhor ranqueados em pelo menos 3 eventos adversos.

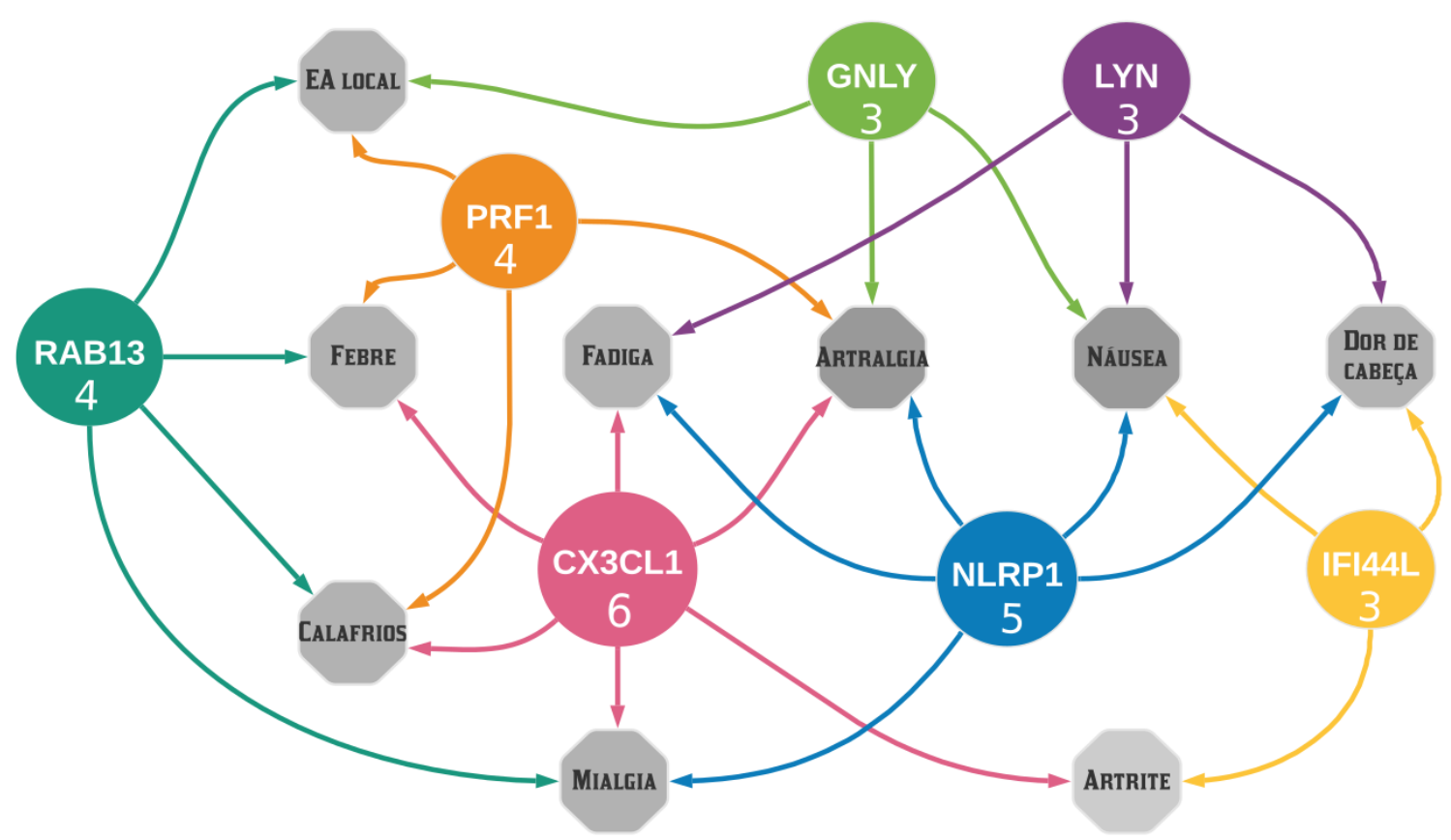

Rede mostrando os genes ranqueados entre os $10 \mathrm{com}$ maiores valores de importância (MDGI) obtidos na classificação de pelo menos 3 eventos eventos adversos diferentes, utilizando o algoritmo Random Forest. Estes resultados foram obtidos a partir dos dados de 
dcRT-MLPA, após a remoção do efeito de lote, dos voluntários vacinados das 4 coortes estudadas no tempo inicial do estudo (Dia 0). O tamanho dos círculos que representam o gene está relacionado ao número de conexões com eventos adversos. A quantidade de eventos adversos é representada pelos números. A intensidade da cor cinza para os octógonos está diretamente relacionada ao número de conexões com genes. O círculo e as setas verdes representam o gene e os eventos adversos para os quais este gene foi selecionado como preditor, respectivamente. O gene $C X 3 C L 1$ e suas conexões são representados pela cor rosa, o gene NLRP1 pela cor azul, o gene PRF1 pela cor alaranjada, o gene $R A B 13$ pela cor verde escuro, o gene IFI44L pela cor amarela, o gene GNLY pela cor verde claro e finalmente o gene $L Y N$ pela cor roxa.

A grande maioria dos eventos adversos registrados após a vacinação com rVSV-ZEBOV são eventos adversos imediatos, isto é, aparecem geralmente até três dias após a vacinação. Esses sintomas são inespecíficos, e em sua maioria leves ou moderados. Em contrapartida, artrite e artralgia são eventos adversos com surgimento tardio. Alguns voluntários que se recuperam da inflamação causada pela artrite continuam com a dor, e esta condição é definida como artralgia. A artrite é notada geralmente dez dias após a vacinação e a artralgia pode surgir também após a cura da artrite. Independentemente da intensidade, eventos adversos como artrite e artralgia costumam causar mais incômodo aos voluntários que os demais eventos adversos de forma individual (HUNTER et al., 2017). Diante disso, a avaliação da artrite foi realizada separadamente, já que a mesma caracteriza-se por um mecanismo diferente dos demais eventos adversos e é dentre todos o mais grave. Em razão disso, a artrite foi o evento adverso mais explorado neste trabalho.

\subsubsection{Definição de Modelo preditivo de Artrite}

A artrite, como citado anteriormente, é o evento adverso mais preocupante induzido pela vacina rVSV-ZEBOV. Inesperadamente, 24 voluntários $(23,5 \%)$ da coorte de Genebra e 19 voluntários (4,5\%) da coorte dos EUA experimentaram artralgias inflamatórias agudas em uma mediana de 11 dias após a vacinação (HEPPNER et al., 2017). O RNA do rVSV foi detectado no líquido sinovial e nas vesículas da pele de alguns destes voluntários, mas nenhuma replicação do vírus pôde ser demonstrada no líquido sinovial. A ocorrência de artrite foi associada à diminuição da contagem de linfócitos no dia 1 (FINCKH et al., 2015; HEPPNER et al., 2017). Deste modo, uma abordagem interessante a fim de evitar estes 
desfechos em futuras populações seria a identificação de genes que são bons preditores de artrite, bem como, a utilização dos mesmos na definição de um modelo preditivo.

Apesar de tanto a coorte dos EUA quanto a de Genebra terem aproximadamente 20 voluntários que relataram artrite, os dados de destes voluntários foram obtidos e disponibilizados, até o momento, apenas para voluntários de Genebra. Portanto, só a coorte de Genebra foi utilizada para a definição de modelos preditivos de artrite. Por se tratar de uma análise de natureza preditiva, apenas os dados de expressão obtidos no dia 0 (antes da vacinação) foram utilizados.

Para definição do modelo preditivo de artrite, foi utilizado os dados de RNA-seq, por se tratar de um conjunto de dados mais completo. O que possibilitaria a identificação de genes não óbvios, ou seja, genes preditores de artrite que poderiam ou não estar diretamente relacionados com o sistema imune. Com este conjunto de dados tínhamos a disponibilidade de amostras para 11 voluntários com artrite e 40 sem artrite. A Figura 23 mostra a dispersão das amostras de voluntários da coorte de Genebra, no tempo inicial, obtidos com RNA-seq.

Figura 23. Dispersão de amostras de voluntários no tempo inicial quanto a incidência ou não de artrite na coorte de Genebra.

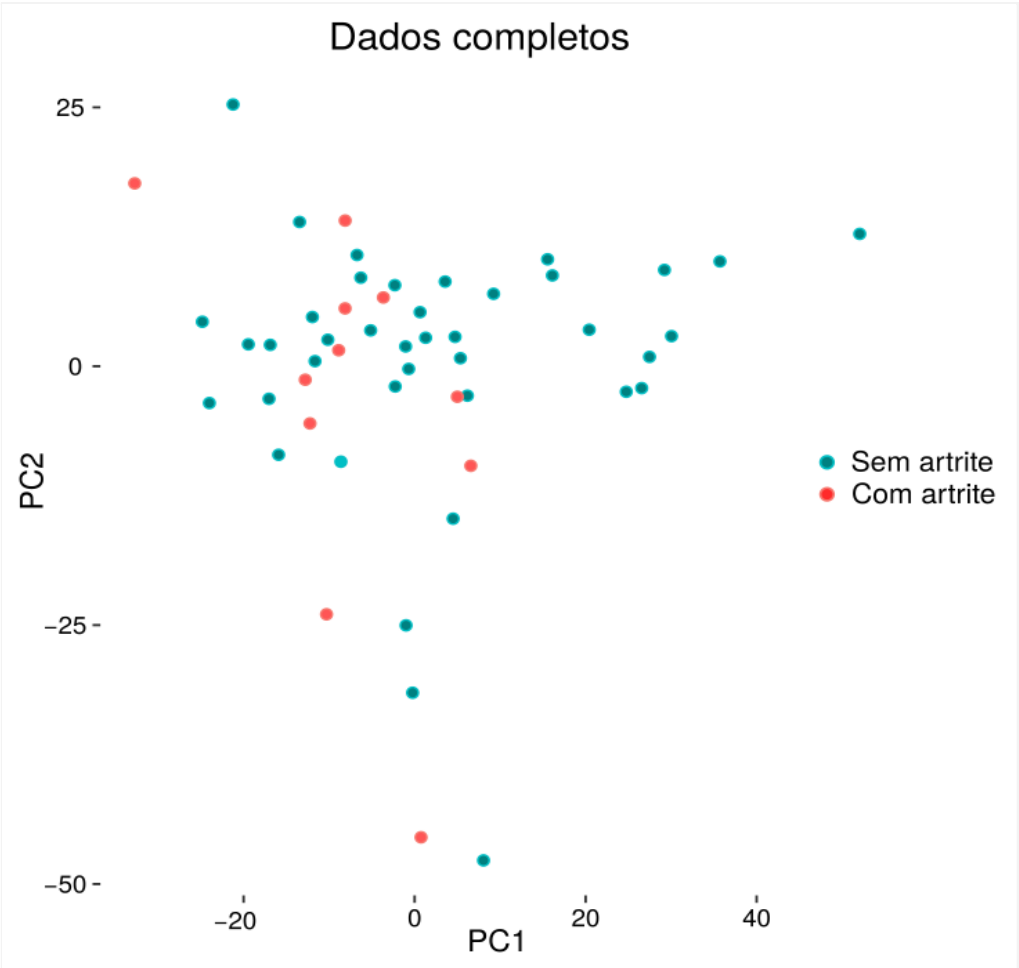

PCA obtido a partir dos dados de RNA-seq no dia 0 (antes da vacinação) cores representam voluntários que desenvolveram (vermelho) ou não (azul) artrite induzida por vacinação. 0 eixo $x$ representa a dispersão das amostras no componente principal 1 (PC1) enquanto o eixo $Y$ representa a dispersão das amostras no componente principal 2 (PC2). 
É possível notar que as amostras dos voluntários no tempo inicial não apresentam uma clara separação entre as classes com e sem artrite. Neste sentido, o uso de abordagens de aprendizado de máquina torna-se uma alternativa, para a separação dos grupos. Já que por meio de métodos estatísticos tradicionais não foi possível identificar nenhuma diferença significativa na expressão dos genes.

Após a divisão do conjunto de dados em treinamento e teste, o primeiro ficou com 36 amostras, dentre estas 29 eram de voluntários sem artrite e 7 de voluntários com artrite, o que corresponde a $70 \%$ do conjunto de dados total. Ao passo que, o segundo conjunto ficou com 15 amostras, 11 delas de voluntários sem artrite e as 4 restantes de voluntários com artrite, o que somados correspondem a $30 \%$ do conjunto de dados total.

Por se tratar de um dado de alta dimensionalidade (14.280 genes) foi realizada uma primeira filtragem por correlação, na qual foram removidos todos os genes com valor de correlação acima de 0.75 , restando 8585 genes. A partir da expressão desses genes foi aplicado o método Boruta e finalmente 5 genes foram selecionados. Sendo eles: MACF1 (do inglês, Microtubule-actin cross-linking factor 1), MRPL11 (do inglês, 39S ribosomal protein L11), XIAP (do inglês, X-linked inhibitor of apoptosis protein), SLC25A2 (do inglês, Mitochondrial Ornithine Transporter 2) e KBTBD3 (do inglês, Kelch Repeat And BTB Domain Containing 3).

Quando utilizamos apenas a expressão destes 5 genes selecionados a partir dos métodos descritos acima, foi possível observar uma melhor separação das classes com e sem artrite a partir das análises de PCA em dados de treino (Figura 24A) e teste (Figura 24B). Quando comparado ao conjunto de dados com todos os genes como mostrado anteriormente na figura 23. 
Figura 24. Dispersão de amostras de voluntários no tempo inicial quanto a incidência ou não de artrite na coorte de Genebra a partir dos 5 genes selecionados para os dados de treino e de teste

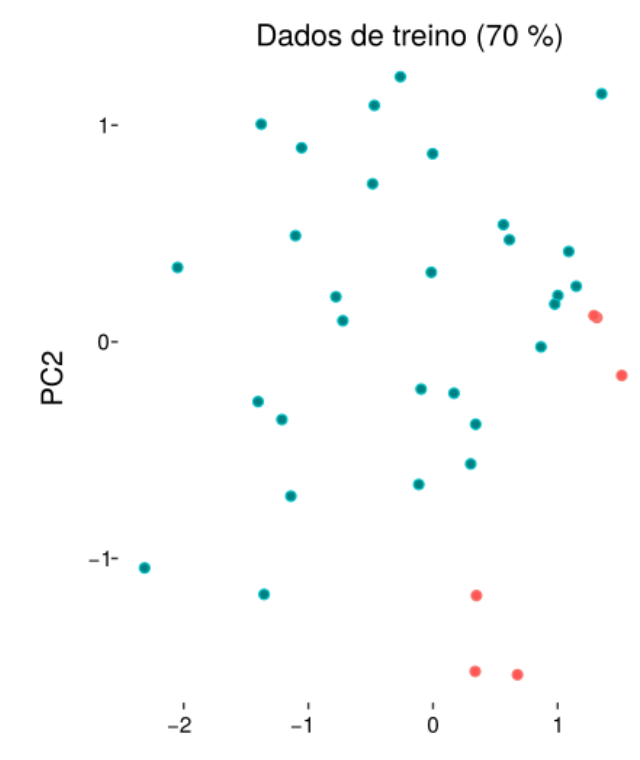

A

PC1

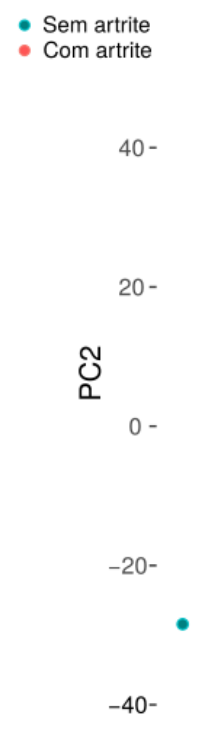

B
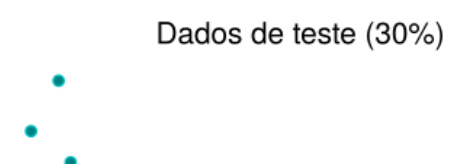

$\cdot$

$\bullet$

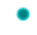

PCA obtido a partir dos dados de RNA-seq no dia 0 (antes da vacinação) para os dados de treinamento $(A)$ e de teste $(B)$. As cores representam voluntários que desenvolveram (vermelho) ou não (azul) artrite induzida por vacinação. $O$ eixo $x$ representa a dispersão das amostras no componente principal 1 (PC1) enquanto o eixo $\mathrm{Y}$ representa a dispersão das amostras no componente principal 2 (PC2).

Quando observamos esses genes em diferentes tempos, podemos notar que a maioria deles têm a expressão diminuída logo no primeiro dia pós-imunização, como é o caso dos genes MACF1, MRPL11, SLC25A2 e KBTBD3. Enquanto que o gene $X I A P$ foi o único que teve sua expressão aumentada após a vacinação (Figura 25). É interessante mencionar, que em nossas análises de expressão diferencial nenhum destes genes foi selecionado como DEGs no dia 1.

Ao comparar a expressão dos genes ainda no dia 0 em relação à incidência ou não de artrite, podemos observar que para todos os genes a classe com artrite tem uma expressão menor, quando comparada a classe sem artrite (Figura 26). Porém, apenas o gene SLC2FA2 teve expressão considerada significativamente diferente $(p$-valor $=0.015)$ a partir do teste de Wilcoxon. Estes resultados foram 
obtidos pela comparação da expressão dos genes individualmente em vacinados que apresentaram ou não artrite.

Figura 25. Expressão dos genes selecionados como preditores de artrite em amostras de voluntários da coorte Genebra em diferentes tempos.
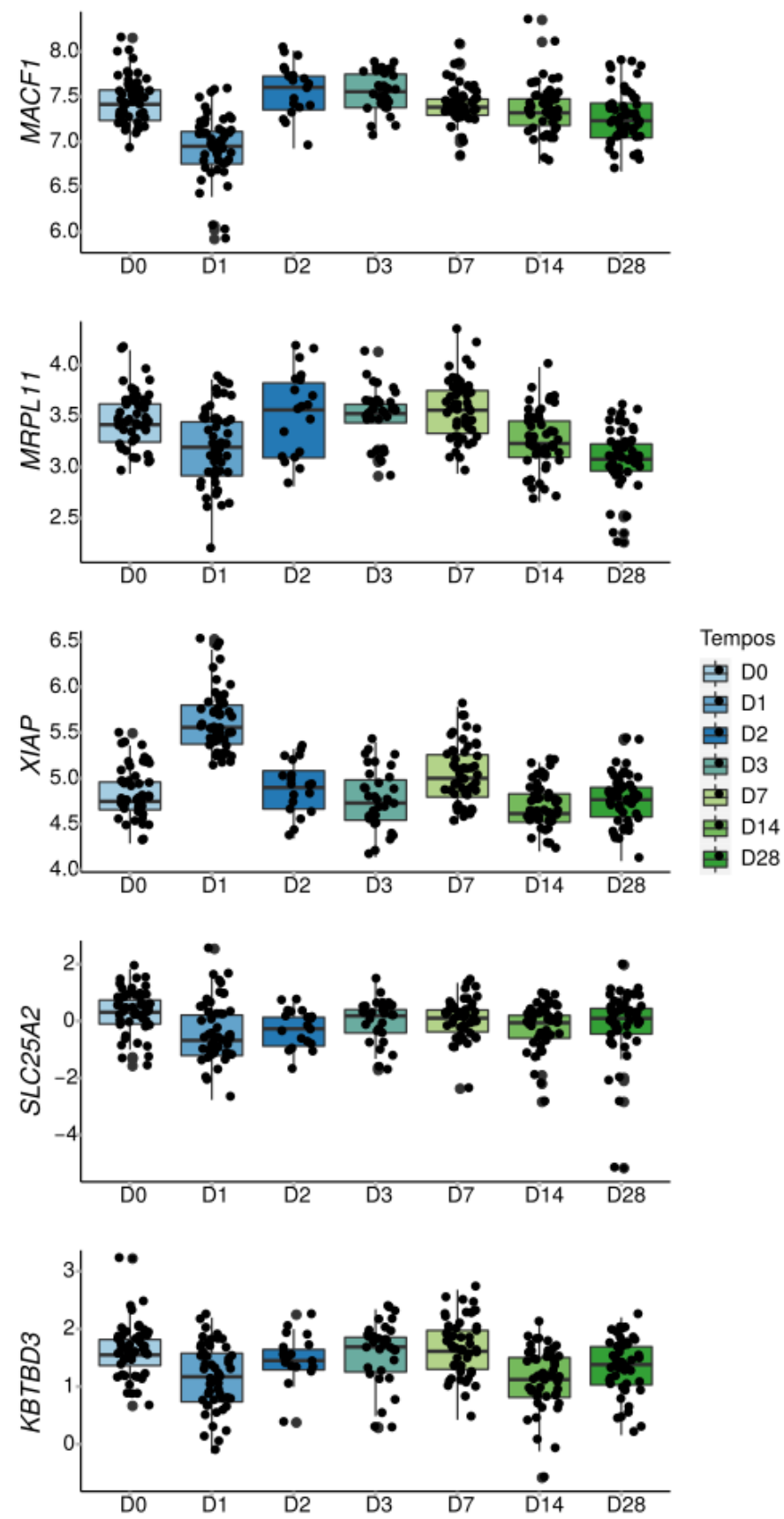

São mostradas as expressões log2 transformadas dos genes selecionados como melhores preditores da classe artrite em diferentes tempos de coleta. A escala de cores representa os 
diferentes tempos. Cada ponto em preto representa o valor de uma amostra e o traço no meio de cada caixa representa a mediana de todas as amostras no mesmo tempo.

Figura 26. Expressão dos genes selecionados como preditores de artrite em amostras de voluntários com ou sem artrite no tempo inicial.
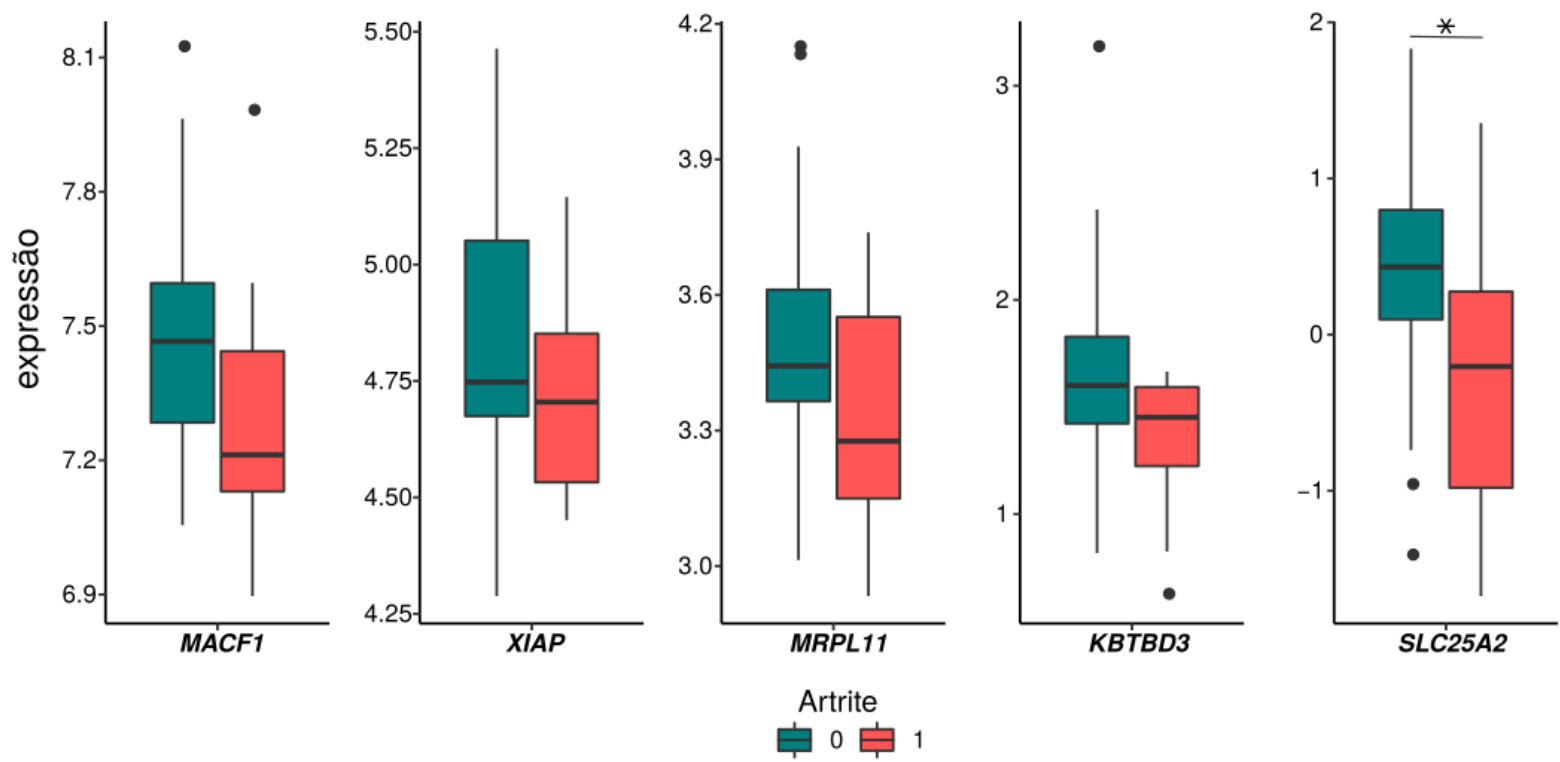

Os boxplots ilustram as expressões dos genes selecionados como melhores preditores da classe artrite no tempo inicial de coleta (dia 0). As cores representam as classes com artrite (vermelho) e sem artrite (azul). Cada ponto em preto representa o valor de uma amostra e o traço no meio de cada caixa representa o valor de mediana de todas as amostras no mesmo tempo. $\mathrm{O}$ * indica o $\mathrm{p}$-valor $<0.05$ obtido a partir do teste de Wilcoxon.

Para a primeira etapa de seleção de genes preditores de artrite, foi realizada a análise de correlação de Spearman, com o intuito de filtrar genes que pudessem trazer informação redundante para o modelo. A partir da expressão dos genes selecionados, foram definidos os subconjuntos de treino e teste para prosseguir com as demais análises. Utilizando o subconjunto de treino, o modelo foi definido e os hiperparâmetros ajustados.

A curva ROC (do inglês, Receiver Operating Characteristics) mostrada abaixo (Figura 27A) representa o resultado de sensibilidade e especificidade obtidos com os dados de treino a partir do modelo ajustado. O valor de AUC (Area under the curve) obtido foi de 0.931. A curva ROC obtida a partir da aplicação dos dados de teste ao modelo preditivo é mostrada na Figura 27B. Nesse conjunto de dados o modelo predito demonstrou uma sensibilidade de 1 e especificidade de 0.692, levando a um valor de curva ROC de 0.864 . 
Figura 27. Curvas ROC dos dados de treino e de teste na predição de artrite utilizando o algoritmo Adaboost.

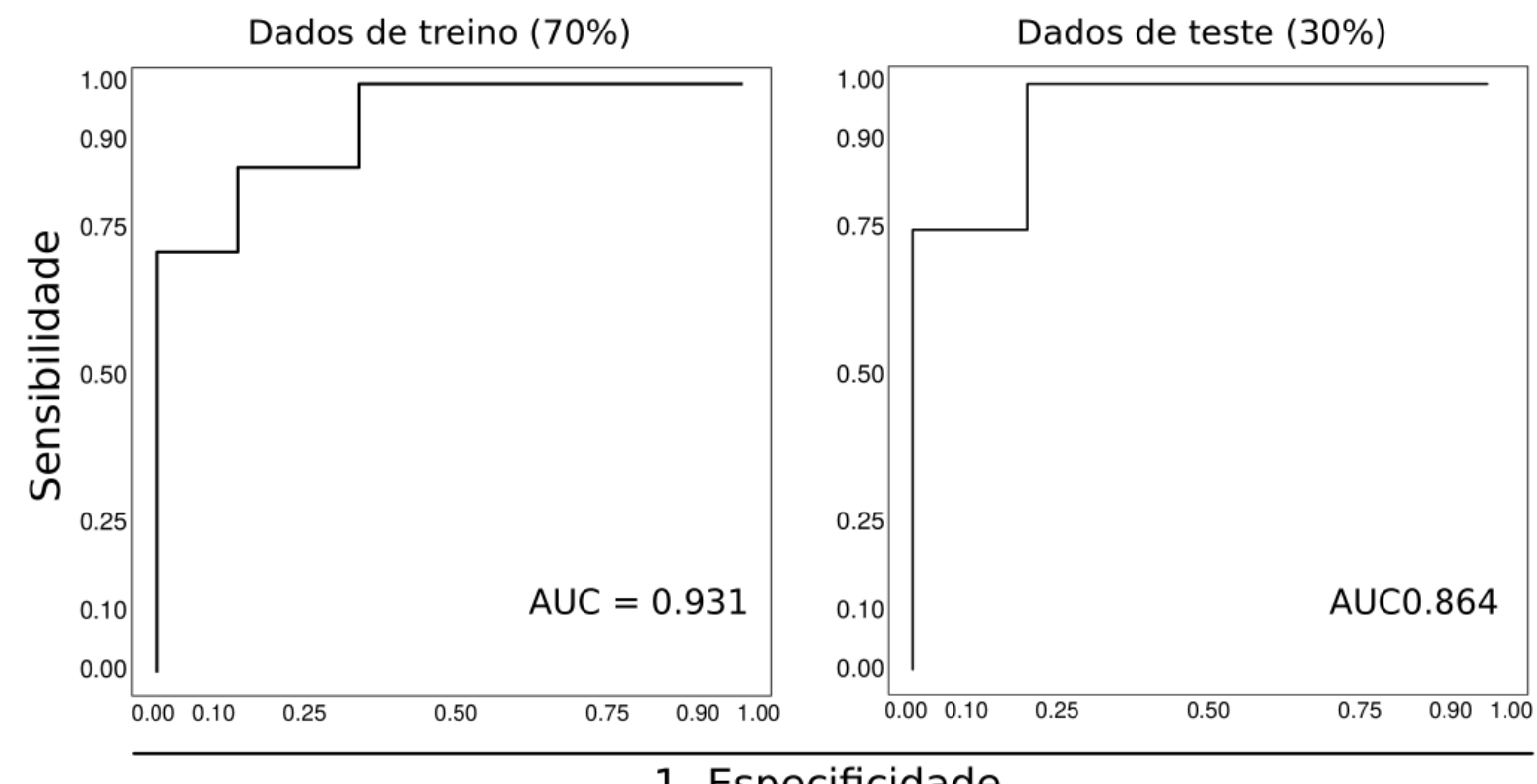

\section{1- Especificidade}

A Curva Característica de operação do receptor (ROC) que representa a Sensibilidade traçada (eixo y) contra 1 - Especificidade (eixo x) e Área sob a curva (AUC) mostram o desempenho de classificação do modelo: $(A)$ nos dados de treino e (B) nos dados de teste.

Tabela 2. Scores obtidos com o modelo de predição de artrite.

Adaboost Acurácia Valor Preditivo positivo Valor preditivo negativo

$\begin{array}{llll}\text { Scores } & 0.867 & 1.000 & 0.818\end{array}$




\section{Discussão}

Devido a alta letalidade da EVD, a imunização é uma importante estratégia de intervenção. A rVSV-ZEBOV foi a primeira vacina aprovada para uso médico ( $\mathrm{CHOI}$ et al., 2021; SUDER et al., 2018). Estudos pré-clínicos demonstraram que esta vacina confere proteção de $100 \%$ em primatas não humanos (JONES et al., 2005), mesmo em doses muito baixas (MARZI et al., 2019). Além disso, em estudos clínicos a mesma demonstrou ser eficaz após a administração de uma dose única, por via intramuscular, em humanos (HENAO-RESTREPO et al., 2017). A eficácia da vacina foi demonstrada em estudos clínicos realizados em 15.399 adultos na Europa (HUTTNER et al., 2015), África (AGNANDJl et al., 2016; REGULES et al., 2017) e América do Norte (COLLER et al., 2017; HALPERIN et al., 2019; HEPPNER et al., 2017). Nestes, a vacina mostrou-se segura, mas apresentou reatogenicidade transitória (HUTTNER et al., 2015).

Sabendo da urgência de uma vacina contra EVD e da dificuldade de desenvolvimento de uma vacina completamente nova, decifrar o papel dos genes no contexto de reatogenicidade e criar alternativas que possibilitem a prevenção de desfechos graves torna-se uma prioridade. Neste sentido, no presente trabalho, foram realizadas análises dos dados de expressão gênica de voluntários imunizados com a vacina rVSV-ZEBOV. Em primeiro lugar, o intuito era compreender a resposta imune induzida por essa vacina a partir de abordagens de Vacinologia de Sistemas. Para posteriormente, fazer a identificação das assinaturas preditoras de determinados eventos adversos a partir algoritmos de aprendizado de máquina.

Na primeira parte do trabalho, que compreende a avaliação da perturbação causada pela vacina ao longo do tempo, foi feita a análise de expressão diferencial com dados de RNA-seq (coorte de Genebra) e de dcRT-MLPA (4 diferentes coortes). Com ambos foi obtido um maior número de DEGs significativamente sobre-expressos, especialmente nos primeiros dias após a vacinação (Figuras $5 \mathrm{e}$ 12, respectivamente). Estes resultados demonstram que a vacinação com rVSV-ZEBOV induz fortes alterações transcriptômicas no sangue dos vacinados, com pico de resposta no dia 1, e se mantêm proeminente até o dia 3, voltando para condições pré-vacinação em aproximadamente 14 dias. Este mesmo perfil foi 
observado por (RECHTIEN et al., 2017) em estudo realizado em uma coorte independente da Alemanha e por Santoro e colaboradores (2021) em estudo com a coorte de Genebra, a mesma avaliada neste trabalho. (RECHTIEN et al., 2017; SANTORO et al., 2021).

Este perfil demonstra que esta vacina é bastante imunogênica e capaz de desencadear uma resposta rápida. Sendo um tipo de resposta similar ao observado em outras infecções virais (RATTERRE et al., 2004; EDWARDS; BASLER, 2019; HALPERIN et al., 2017), e pode ser explicada ao fato desta vacina ser baseada em um vírus vivo replicante (EDWARDS; BASLER, 2019; GARBUTT et al., 2004; HALPERIN et al., 2017). Esta resposta também é similar à descrita na patogênese da doença por vírus Ebola. A mesma é associada a uma super ativação de sistema inflamatório inato, com a ativação de genes de interferon detectados nos primeiros dias de infecção (BRAY; GEISBERT, 2005; SPERANZA; CONNOR, 2017). Estes achados foram publicados em diferentes estudos. Um deles fez o comparativo de resposta transcricional em humanos que sobreviveram ou não à infecção ao vírus Ebola, e descreveu resposta de interferon e tempestade de citocinas em níveis mais elevados em desfechos fatais (CROSS et al., 2018; LIU et al., 2017). Enquanto o outro estudo fez análises comparativas entre furões, primatas não humanos e humanos, revelando diversas vias do sistema imune compartilhadas entre as espécies, principalmente vias com papel em receptores de reconhecimento de padrões de vírus e resposta imune inata contra vírus (CROSS et al., 2018; LIU et al., 2017).

Os DEGs da comparação do dia 1 versus o dia 0 estavam relacionados à resposta imune inata e inflamatória, e à sinalização de interferon, demonstrando a capacidade imunogênica da vacina rVSV-ZEBOV. Este mesmo perfil de resposta também foi obtido a partir de análises realizadas por pesquisadores alemães, que avaliaram as amostras de voluntários vacinados com a mesma vacina (RECHTIEN et al., 2017). Nela, os genes sobre-regulados da comparação dia 1 e dia 0 , enriqueceram para vias que incluíam a via de sinalização do interferon, a via de receptores de reconhecimento de padrões em reconhecimento de bactérias e vírus, e a via de inflamassoma (RECHTIEN et al., 2017). 
A vacinação teve um impacto sustentado nos módulos de genes associados à imunidade inata. Isso possivelmente resultou em maior proteção contra infecção viral e induziu uma assinatura transcricional de resposta imune adaptativa. A resposta adaptativa, como demonstrado por Santoro e colaboradores (2021), está correlacionada com os títulos de anticorpos anti-GP de ebola (SANTORO et al., 2021).

Quanto à análise dos genes em redes foram criadas redes gênicas a partir de informação de interação proteína-proteína para os dados de RNA-seq, geradas a partir da lista de genes superexpressos no dia 1. Foram realizadas também análises para identificação de redes de coexpressão, mas neste caso com dados de dcRT-MLPA para as coortes Genebra, Kilifi, Gabão e EUA e RNA-seq para a coorte Genebra a partir de amostra em todos os tempos.

Nas redes de interação proteína-proteína alguns genes se destacaram como hubs, entre eles os genes CDKN1A, FBXO6, HSPA1B, HSPA1A, MOV10. Os primeiros dois genes foram identificados como hubs também nas análises de interação a partir dos módulos de coexpressão identificados. O gene CDKN1A codifica um potente inibidor de quinase dependente de ciclina e portanto funciona como um regulador da progressão do ciclo celular em G1 (DULIC et al., 1994). O mesmo gene também desempenha um papel na regulação da quiescência e da entrada na fase $S$ no caso de um ciclo celular não perturbado (OVERTON et al., 2014). Já o gene FBXO6, tem atividade na proteína ubiquitina transferase (CENCIARELLI et al., 1999).

FBXO6 foi identificado como hub também em resultados de coexpressão juntamente com o gene UBC. Enquanto o gene FBXO6 tem atividade na proteína ubiquitina transferase (CENCIARELLI et al., 1999), o gene UBC (Ubiquitin C), de modo interessante, codifica a proteína ubiquitina (HEATON; BORG; DIXIT, 2016), exercendo funções que incluem a ligação de proteases. Isto indica a importante atuação das ubiquitinas na regulação de proteínas após a infecção com o vírus vacinal. Considerando o fato de que com a invasão do mesmo nas células é necessário fazer a ubiquitinação de proteínas indesejadas. Este é o caso tanto da glicoproteína do vírus ebola quanto das demais proteínas com má formação ou 
degradadas por meio da ação do vírus (GAO; LUO, 2006). Por exemplo, o gene $U B C$ é considerado um gene protetor do estresse e é regulado sob várias condições estressantes, como a infecção viral por exemplo, o que é provavelmente uma conseqüência de uma maior demanda por ubiquitina para remover proteínas tóxicas mal dobradas (HEATON; BORG; DIXIT, 2016).

Ainda na análise de coexpressão o gene $L Y N$ foi identificado como hub em módulos obtidos a partir da coorte Genebra (dcRT-MLPA e RNA-seq), Kilifi (dcRT-MLPA), Gabão (dcRT-MLPA) e EUA (dcRT-MLPA). Este gene que codifica a proteína tirosina quinase, tem papel central na transdução de sinal e está relacionado a processos como proliferação, diferenciação, mobilidade, sobrevivência ou morte celular de células B (RADHA et al., 1996; DALLARI et al., 2017).

Embora a coorte não tenha influenciado tanto os resultados de expressão diferencial e coexpressão, a mesma demonstrou ser a variável mais influente na variância das amostras considerando dados pré-vacinação (Figuras 11 e 12 A). Esta realidade demonstra a influência do método de obtenção da amostra e da variação dos dados intrínseca à coorte (fatores de risco, predisposição genética, intervenções terapêuticas, fatores culturais etc.) (LÉVY et al., 2018), que fica proeminente em dados de pessoas em estado "normal" (pré-vacinação). Por esta razão, o efeito da coorte e da dose foram removidos dos dados antes da vacinação. A dispersão após remoção do efeito de lote ficou mais uniforme, não sendo possível observar uma clara separação entre amostras das diferentes coortes (Figura 12B).

Quando aplicando o método Random Forest para os dados das 4 coortes em conjunto, os genes com maior soma de importância para todos os eventos adversos foram selecionados (Figura 21). Também foram selecionados os genes entre os 10 melhor ranqueados na predição de ao menos 3 eventos adversos. Dentre eles o gene de maior destaque foi o CX3CL1, selecionado para 6 eventos adversos (Artralgia, Fadiga, Febre, Artrite, Mialgia e Calafrios). Este gene e seu receptor CX3CR1 pertencem a uma família de receptores acoplados à proteína $\mathrm{G}$ e diversos estudos apontam o gene CX3CR1 como tendo papel central na fisiopatologia de doenças na inflamatórias (HOU; HOU; LIU, 2017), o que corrobora a importância 
deste gene nos eventos adversos apontados, principalmente em Artralgia, Artrite e Mialgia.

Por exemplo, quando os níveis de CX3CL1 no líquido sinovial e no soro foram ambos descobertos serem positivamente associados com a Osteoartrite (HOU; HOU; LIU, 2017). Além disso, várias evidências sugerem que as interações CX3CL1 - CX3CR1 contribuem para o desenvolvimento de doenças inflamatórias, como a artrite reumatóide (AR) (CLARK; STANILAND; MALCANGIO, 2011; NANKI; IMAI; KAWAI, 2017). Já que este gene é superexpresso no soro, sinóvia, líquido sinovial e cartilagem de pacientes com AR (NANKI; IMAI; KAWAI, 2017; ODAl et al., 2009).

Enquanto isso, O gene NLRP1 foi selecionado entre os top 10 preditores de 5 eventos adversos (Artralgia, Fadiga, Náusea, Mialgia e Dor de cabeça). Este é um gene receptor que compõe o complexo chamado inflamassoma, cuja função normal é a síntese de IL-18 e de IL-1 $1 \beta$. Esse complexo é essencial para que o sistema imune inato atue de forma eficaz contra patógenos (vírus, fungos e bactérias) e contra outras doenças. Além disso, o mesmo atua na regulação de processos metabólicos e de resposta imune de mucosa (GOLDBACH-MANSKY; KASTNER, 2009; SÁ; FESTA, 2016; STROWIG et al., 2012). Porém, alguns efeitos deletérios podem ocorrer, quando a atividade do complexo torna-se excessiva. Inflamassomas têm sido implicados em diversas patologias (GOLDBACH-MANSKY; KASTNER, 2009), como por exemplo as doenças febris hereditárias, doenças neurológicas (Alzheimer, esclerose múltipla) (FREEMAN; TING, 2016; PONTILLO et al., 2012b), bem como, doenças autoimunes (vitiligo, artrite reumatóide, diabetes tipo 1, doença de Addison, lúpus eritematoso) (MAGITTA et al., 2009; PONTILLO et al., 2012a). Deste modo, a propensão do hospedeiro a uma super estimulação de inflamassomas, pode estar associada a uma predisposição ao desenvolvimento de eventos adversos.

Outro gene foi o $P R F 1$, selecionado entre os melhores preditores para 4 eventos adversos (Artralgia, Febre, Evento adverso local e Calafrios). Esse gene codifica a perforina, uma proteína encontrada nos grânulos intracelulares das células NK e T citotóxicas e que é um fator chave nos processos de lise mediados 
por essas células. Um estudo recente mostrou que células T CAR (do inglês, Chimeric antigen receptor $T$ cells) deficientes em perforina recapitulam toxicidades inflamatórias de início tardio observadas em pacientes que apresentam sintomas semelhantes à síndrome inflamatória sistêmica (sepse), na ausência de qualquer etiologia infecciosa detectável. Neste estudo, após a ativação in vitro mediada por CAR, as células T CAR deficientes em perforina produziram maiores quantidades de citocinas pró-inflamatórias, como IL-18 e IL-1 $\beta$, em comparação com as células T CAR normais. Após a eliminação in vivo da leucemia, as células T CAR deficientes em perforina se expandiram novamente, resultando em esplenomegalia com ruptura da arquitetura esplênica normal e a presença de hemofagócitos, que são achados que lembram linfo-histiocitose hemofagocítica (ISHII et al., 2020). No contexto de infecção, as células NK no sangue periférico de pacientes com chikungunya crônica também expressam níveis reduzidos de perforina (THANAPATI et al., 2017), a porcentagem de células NK perforina positiva foi baixa em ambos os grupos de pacientes com artrite crônica (THANAPATI et al., 2017). O que poderia associar a redução da quantidade de perforina a um marcador de reações adversas causadas por maiores quantidades de citocinas pró-inflamatórias.

Entre os genes selecionados para 4 eventos adversos está o gene RAB13 ranqueado para Febre, Evento adverso local, Mialgia e Calafrios. RAB13, faz parte da maior subfamília da pequena superfamília RAS de GTPases, que são os principais reguladores da endocitose por meio do direcionamento de vesículas intracelulares e cargas para compartimentos subcelulares apropriados (DELEVOYE; GOUD, 2015; MITRA; CHENG; MILLS, 2011). Como a carga vesicular inclui fatores de crescimento, nutrientes, citocinas, integrinas e até agentes patogênicos. Para este último, o papel do mesmo foi descrito em infecções virais em mamíferos (MITRA; CHENG; MILLS, 2011; ORGAN et al., 2004; SPEARMAN, 2018). Os vírus se envolvem com vias de tráfego celular relacionadas a Rab em diversos momentos do ciclo, sendo um deles relacionado à classificação de glicoproteínas de envelope final. Estas proteínas podem ser direcionadas para locais intracelulares por endocitose para endossomos iniciais ou endossomo de reciclagem (MITRA; CHENG; MILLS, 2011; ORGAN et al., 2004; SPEARMAN, 2018). Por ter um papel importante no ciclo viral, presume-se que alterações no nível de expressão deste 
gene podem inferir na intensidade da resposta viral e consequentemente na percepção de eventos adversos.

Os genes com maior soma de importância preditiva para todos os eventos adversos tiveram baixa importância na predição de artrite (Figura 20). Por este ser o evento adverso mais grave, foi definido um modelo preditivo exclusivo para artrite. Os genes MACF1, MRPL11, XIAP, SLC25A2 e KBTBD3 foram os selecionados como mais importantes na predição da artrite (Figuras 25 e 26).

Alguns desses genes, como o gene MACF1 e o gene XIAP, são relacionados a estudos envolvendo artrite. O primeiro é apontado como um gene associado a doença de artrite reumatóide no GWAS (do inglês, Gene Wide Association Study). Esse gene é citado como um biomarcador em um pedido de patente aberto no Canadá para tratamento de artrite reumatóide (CA2802912A1 - 2011) (MOOKHERJEE N.,2011). No entanto, não há descrição na literatura sobre o mecanismo pelo qual MACF11 relaciona-se à artrite.

Quanto a relação do gene XIAP com artrite, dados de um estudo publicado por Niederer e colaboradores (2012) fornecem evidências de uma regulação negativa específica da metilação de miR-34a pró-apoptótico em fibroblastos sinoviais de artrite reumatóide. A expressão diminuída de miR-34a* resultaria na regulação positiva de seu alvo direto $X I A P$, contribuindo assim para a resistência dos fibroblastos sinoviais de artrite reumatóide à apoptose. O papel do XIAP na artrite, foi uma descoberta importante fornecida por Dharmapatni e colaboradores (2015) que mostrou que o nível de XIAP e outro fator anti-apoptose, survivina, foram significativamente elevados no tecido sinovial de pacientes com AR ativa (DHARMAPATNI et al., 2015).

Mesmo que não necessariamente os genes selecionados por técnicas de aprendizado de máquina tenham relação de causalidade com as classes de interesse. Ou seja, mesmo que estes não tenham papel biológico com as classes preditas. Esses podem nos trazer informações sobre como esses padrões ajudaram na classificação dos grupos. Desta forma, os genes selecionados podem possibilitar a identificação de pacientes susceptíveis, mesmo sem terem relação biológica 
estrita com o desenvolvimento de reações adversas. À vista disso, estas abordagens de aprendizado de máquina são promissoras e podem ser ferramentas úteis para um maior controle de reações pós-vacinação.

Nossos resultados mostram que os genes selecionados, não seguem um padrão único de expressão pós vacinação (Figura 25), mas nota-se que a expressão dos genes no tempo inicial é diminuída em voluntários com artrite (Figura 26). Estes resultados podem indicar que a expressão aumentada desses genes em pessoas que não desenvolveram artrite pode ter atuado como um fator protetor.

Em conjunto, e com o algoritmo de Adaboost, nosso modelo preditivo foi capaz de prever a classe artrite positiva, com 100\% de acurácia (Tabela 2). Este resultado é bastante animador, já que foram necessários apenas 5 genes para sua definição. Mesmo assim, muito ainda pode ser feito no sentido de aprimorar este modelo, já que a quantidade de amostras é uma grande limitação. Considerando a quantidade mínima de amostras utilizadas para a implementação do modelo, o peso de cada uma delas acaba sendo altíssimo (DOBBIN; ZHAO; SIMON, 2008; FIGUEROA et al., 2012). Esta realidade torna o modelo pouco generalista e muitas vezes sobre ajustado (FIGUEROA et al., 2012), o que dificulta a implementação do mesmo para ser utilizado em dados reais (população futura).

Além disso, nossos dados apresentam classes desbalanceadas, o que induz o algoritmo a aprender principalmente a classe majoritária. Diversas abordagens podem ser aplicadas para lidar com esse desbalanceamento, como aumentar o número de amostras minoritárias, reduzir a classe majoritária, ou igualar as classes (KUHN et al., 2016). No entanto, pelo fato de o número de amostras ser pequeno, qualquer um desses processos adicionaria um viés técnico aos dados. Como nossa intenção era extrair informação dos dados, manter a disposição original das amostras foi a abordagem mais satisfatória. No sentido de garantir a aplicabilidade do modelo, as amostras que estão sendo obtidas a partir dos estudos clínicos de fase 2 e 3 do consórcio científico VSV-EBOPLUS, serão utilizadas a fim de aprimorar esse modelo e torná-lo aplicável a dados futuros. 
O mesmo processo de definição de modelo preditivo pode ser refeito a fim de encontrar preditores comuns às demais coortes. Essa abordagem permitiria o desenvolvimento de modelos mais robustos e eficientes para lidar com esses dados para diferentes perfis populacionais. Neste caso, não só aplicado à artrite, mas também aos demais eventos adversos relatados.

Em resumo, este estudo aponta percepções sobre a resposta imune induzida pela vacinação com rVSV-ZEBOV. O mesmo também dá indícios da possível relação entre a expressão de alguns genes e a propensão do hospedeiro ao desenvolvimento de alguns eventos adversos. Contudo, mais pesquisas nesse sentido são necessárias para caracterizar a relação dos genes com os eventos adversos. Sendo estas relações aplicáveis não só no contexto de vacinação com rVSV-ZEBOV, mas também em outros contextos vacinais e infecciosos. 


\section{Conclusão}

Com este estudo nós traçamos o perfil da resposta transcriptômica do sangue na primeira semana após a vacinação com a rVSV-ZEBOV, para as quatro diferentes coortes. Além disso, comparamos inclusive assinaturas obtidas por métodos de obtenção de transcriptoma diferentes dentro da coorte de Genebra, proporcionando uma importante contribuição para a identificação de assinaturas imunes da rVSV-ZEBOV, que é a primeira vacina de Ebola aprovada para uso clínico. Nossos resultados demonstram que a vacina induz uma resposta tipicamente viral com ativação principalmente de vias de interferon e com vias relacionadas à resposta imune adaptativa enriquecidos a partir do dia 7. Por meio das análises de coexpressão foram identificados módulos de genes com função na resposta imune e de defesa do hospedeiro.

Neste estudo também focamos em análises preditivas, utilizando os dados dos voluntários antes da vacinação, para identificar assinaturas intrínsecas ao hospedeiro que nos dessem pistas da reatogenicidade induzida após a vacinação com rVSV-ZEBOV. Com nosso estudo, foi possível identificar alguns genes preditores de diferentes eventos adversos. A partir da expressão de 5 genes definimos um modelo capaz de classificar voluntários com ou sem artrite com boa precisão. Mesmo assim, esses modelos precisam ser melhorados, o que seria possível, principalmente, com o aumento do número de amostras. 


\section{Referências Bibliográficas}

AGNANDJI, S. T. et al. Phase 1 Trials of rVSV Ebola Vaccine in Africa and Europe. The New England Journal of Medicine, v. 374, n. 17, p. 1647-1660, 28 Apr. 2016.

AMMAN, B. R. et al. Ecology of Filoviruses. Current Topics in Microbiology and Immunology, v. 411, p. 23-61, 2017.

ANDRE, F. E. et al. Vaccination greatly reduces disease, disability, death and inequity worldwide. Bulletin of the World Health Organization, v. 86, n. 2, p. 140-146, Feb. 2008.

BASTIAN, M.; HEYMANN, S.; JACOMY, M. Gephi: An Open Source Software for Exploring and Manipulating Networks. Third Int. AAAI Conf. Weblogs Soc. Media, p. 361-362, 1 Jan. 2009.

BAZZILL, J. D. et al. Vaccine nanoparticles displaying recombinant Ebola virus glycoprotein for induction of potent antibody and polyfunctional $T$ cell responses. Nanomedicine: nanotechnology, biology, and medicine, v. 18, p. 414-425, 2019.

BECKER, S. et al. Interactions of Marburg virus nucleocapsid proteins. Virology, v. 249, n. 2, p. 406-417, 30 Sep. 1998.

BENCH-CAPON, T. J. M.; DUNNE, P. E. Argumentation in artificial intelligence. Artificial intelligence, v. 171, n. 10-15, p. 619-641, Jul. 2007.

BHARAT, T. A. M. et al. Structural dissection of Ebola virus and its assembly determinants using cryo-electron tomography. Proceedings of the National Academy of Sciences of the United States of America, v. 109, n. 11, p. 4275-4280, 13 Mar. 2012.

BISHOP, C.M. Neural Networks for Pattern Recognition. Clarendon Press, Oxford, 1996.

BLANEY, J. E. et al. Antibody quality and protection from lethal Ebola virus challenge in nonhuman primates immunized with rabies virus based bivalent vaccine. PLoS Pathogens, V. 9, n. 5, p. e1003389, 30 May 2013.

BRAY, M.; GEISBERT, T. W. Ebola virus: the role of macrophages and dendritic cells in the pathogenesis of Ebola hemorrhagic fever. The International Journal of Biochemistry \& Cell Biology, v. 37, n. 8, p. 1560-1566, Aug. 2005.

BREIMAN, L. Random Forests. Machine Learning, 2011.

BREUER, K. et al. InnateDB: systems biology of innate immunity and beyond--recent updates and continuing curation. Nucleic Acids Research, v. 41, n. Database issue, p. D1228-33, Jan. 2013.

BROWN, G. et al. Conditional Likelihood Maximisation: A Unifying Framework for Information Theoretic Feature Selection. Journal of Machine Learning Research, 2012.

BUKREYEV, A. et al. Successful topical respiratory tract immunization of primates against Ebola virus. Journal of Virology, v. 81, n. 12, p. 6379-6388, Jun. 2007.

BUKREYEV, A. A. et al. Mucosal parainfluenza virus-vectored vaccine against Ebola virus replicates in the respiratory tract of vector-immune monkeys and is immunogenic. Virology, v. 399, n. 2, p. 290-298, 10 Apr. 2010.

BUKREYEV, A. A. et al. Discussions and decisions of the 2012-2014 International 
Committee on Taxonomy of Viruses (ICTV) Filoviridae Study Group, January 2012-June 2013. Archives of Virology, v. 159, n. 4, p. 821-830, Apr. 2014.

BUSHEL P. pvca: Principal Variance Component Analysis (PVCA). R package version 1.24.0, 2019.

CALUWAERTS, S. et al. Dilemmas in managing pregnant women with ebola: 2 case reports. Clinical Infectious Diseases, v. 62, n. 7, p. 903-905, 1 Apr. 2016.

CENCIARELLI, C. et al. Identification of a family of human F-box proteins. Current Biology, v. 9, n. 20, p. 1177-1179, 21 Oct. 1999.

CENTERS FOR DISEASE CONTROL AND PREVENTION (CDC). Ten great public health achievements--United States, 1900-1999. MMWR. Morbidity and Mortality Weekly Report, v. 48, n. 12, p. 241-243, 2 Apr. 1999.

CHEN, Y.-L., Hu, H.-W. e Tang, K. Constructing a decision tree from data with hierarchical class labels, Expert Systems with Applications, pp. 4838-4847, 2009.

CHEN, E. Y. et al. Enrichr: interactive and collaborative HTML5 gene list enrichment analysis tool. BMC Bioinformatics, v. 14, p. 128, 15 Apr. 2013.

CHERTOW, D. S. et al. Ebola virus disease in West Africa--clinical manifestations and management. The New England Journal of Medicine, v. 371, n. 22, p. 2054-2057, 27 Nov. 2014.

$\mathrm{CHOI}, \mathrm{M}$. J. et al. Use of ebola vaccine: recommendations of the advisory committee on immunization practices, united states, 2020. MMWR. Recommendations and Reports: Morbidity and Mortality Weekly Report, v. 70, n. 1, p. 1-12, 8 Jan. 2021.

CLARKE, E. C. et al. Production and purification of filovirus glycoproteins in insect and mammalian cell lines. Scientific Reports, v. 7, n. 1, p. 15091, 8 Nov. 2017.

CLARK, A. K.; STANILAND, A. A.; MALCANGIO, M. Fractalkine/CX3CR1 signalling in chronic pain and inflammation. Current Pharmaceutical Biotechnology, v. 12, n. 10, p. 1707-1714, Oct. 2011.

CLARK, D. V. et al. Long-term sequelae after Ebola virus disease in Bundibugyo, Uganda: a retrospective cohort study. The Lancet Infectious Diseases, v. 15, n. 8, p. 905-912, Aug. 2015.

CLEMENTS, C. J.; LARSEN, G.; JODAR, L. Technologies that make administration of vaccines safer. Vaccine, v. 22, n. 15-16, p. 2054-2058, 7 May 2004.

COLLER, B.-A. G. et al. Clinical development of a recombinant Ebola vaccine in the midst of an unprecedented epidemic. Vaccine, v. 35, n. 35 Pt A, p. 4465-4469, 16 Aug. 2017.

CROSS, R. W. et al. Comparative Transcriptomics in Ebola Makona-Infected Ferrets, Nonhuman Primates, and Humans. The Journal of Infectious Diseases, v. 218, n. suppl_5, p. S486-S495, 22 Nov. 2018.

DALLARI, S. et al. Src family kinases Fyn and Lyn are constitutively activated and mediate plasmacytoid dendritic cell responses. Nature Communications, v. 8, p. 14830, 3 Apr. 2017.

DAS, S. K. Feature Selection with a Linear Dependence Measure. IEEE Transactions on 
Computers, v. C-20, n. 9, p. 1106-1109, Sep. 1971.

DAVIS, N. A. et al. Surfing a genetic association interaction network to identify modulators of antibody response to smallpox vaccine. Genes and Immunity, v. 11, n. 8, p. 630-636, Dec. 2010.

DELEVOYE, C.; GOUD, B. Rab GTPases and kinesin motors in endosomal trafficking. Methods in Cell Biology, v. 130, p. 235-246, 7 Jul. 2015.

DE LIMA, D. S. et al. Long noncoding RNAs are involved in multiple immunological pathways in response to vaccination. Proceedings of the National Academy of Sciences, 116 (34) 17121-17126; Aug. 2019.

DHARMAPATNI, A. A. S. S. K. et al. The X-Linked Inhibitor of Apoptosis Protein Inhibitor Embelin Suppresses Inflammation and Bone Erosion in Collagen Antibody Induced Arthritis Mice. Mediators of Inflammation, v. 2015, p. 564042, 4 Aug. 2015.

DIALLO, B. et al. Resurgence of ebola virus disease in guinea linked to a survivor with virus persistence in seminal fluid for more than 500 days. Clinical Infectious Diseases, v. 63, n. 10, p. 1353-1356, 15 Nov. 2016.

DIXON, M. G.; SCHAFER, I. J.; CENTERS FOR DISEASE CONTROL AND PREVENTION (CDC). Ebola viral disease outbreak--West Africa, 2014. MMWR. Morbidity and Mortality Weekly Report, v. 63, n. 25, p. 548-551, 27 Jun. 2014.

DOBBIN, K. K.; ZHAO, Y.; SIMON, R. M. How large a training set is needed to develop a classifier for microarray data? Clinical Cancer Research, v. 14, n. 1, p. 108-114, 1 Jan. 2008.

EUROPEAN CENTRE FOR DISEASE PREVENTION AND CONTROL. Ebola virus disease outbreak in Guinea, 2021 - 22 February 2021. ECDC: Stockholm; 2021.

EDWARDS, M. R.; BASLER, C. F. Current status of small molecule drug development for Ebola virus and other filoviruses. Current opinion in virology, v. 35, p. 42-56, 16 Apr. 2019.

EMA a. Supporting the development of Ebola medicines. 2019. Disponível em: https://www.ema.europa.eu/en/human-regulatory/overview/public-health-threats/ebola.

Acesso em: 23 de fev. 2021.

EMA b. Zabdeno, INN-Ebola vaccine (Ad26.ZEBOV-GP [recombinant]. 2019. Disponível em: https://www.ema.europa.eu/en/documents/product-information/zabdeno-epar-product-inform ation_pt.pdf. Acesso em: 23 de fev. 2021.

EMA a. (2020). Zabdeno. Disponível em: https://www.ema.europa.eu/en/medicines/human/EPAR/zabdeno. 2020. Acesso em: 23 de fev. 2021.

EMA b. Mvabea (MVA-BN-Filo, recombinant). 2020. Disponível em: https://www.ema.europa.eu/en/documents/overview/mvabea-epar-medicine-overview en.pdf . Acesso em: 23 de fev. 2021.

EMANUEL, J.; MARZI, A.; FELDMANN, H. Filoviruses: ecology, molecular biology, and evolution. Advances in virus research, v. 100, p. 189-221, 1 Feb. 2018. 
ESSEGHIR, M. A. Effective wrapper-filter hybridization through grasp schemata, Journal of Machine Learning Research - Proceedings Track pp. 45-54, 2010.

FABREGAT, A. et al. The Reactome Pathway Knowledgebase. Nucleic Acids Research, v. 46, n. D1, p. D649-D655, 4 Jan. 2018.

FDA. First FDA-approved vaccine for the prevention of Ebola virus disease, marking a critical milestone in public health preparedness and response. 2019. Disponível em: https://www.fda.gov/news-events/press-announcements/first-fda-approved-vaccine-preventio n-ebola-virus-disease-marking-critical-milestone-public-health. Acesso em: 23 de fev. 2021.

FIGUEROA, R. L. et al. Predicting sample size required for classification performance. BMC Medical Informatics and Decision Making, v. 12, p. 8, 15 Feb. 2012.

FINCKH, A. et al. THU0245 Post-Vaccinal Arthritis in an Ebola Vaccine Trial with a Live-Attenuated Recombinant Virus Expressing the Ebola Surface Glycoprotein (RVSV-ZEBOV). Annals of the Rheumatic Diseases, v. 74, n. Suppl 2, p. 286.1-286, Jun. 2015.

FLANAGAN-KLYGIS, E. A.; SHARP, L.; FRADER, J. E. Dismissing the family who refuses vaccines: a study of pediatrician attitudes. Archives of Pediatrics \& Adolescent Medicine, v. 159, n. 10, p. 929-934, Oct. 2005.

FOLB, P. I. et al. A global perspective on vaccine safety and public health: the Global Advisory Committee on Vaccine Safety. American Journal of Public Health, v. 94, n. 11, p. 1926-1931, Nov. 2004.

FREEMAN, L. C.; TING, J. P.-Y. The pathogenic role of the inflammasome in neurodegenerative diseases. Journal of Neurochemistry, v. 136 Suppl 1, p. 29-38, Jan. 2016.

GAO, G.; LUO, H. The ubiquitin-proteasome pathway in viral infections. Canadian Journal of Physiology and Pharmacology, v. 84, n. 1, p. 5-14, Jan. 2006.

GARBUTT, M. et al. Properties of replication-competent vesicular stomatitis virus vectors expressing glycoproteins of filoviruses and arenaviruses. Journal of Virology, v. 78, n. 10, p. 5458-5465, May 2004.

GEISBERT, T. W. et al. Vesicular stomatitis virus-based ebola vaccine is well-tolerated and protects immunocompromised nonhuman primates. PLoS Pathogens, v. 4, n. 11, p. e1000225, 28 Nov. 2008.

GOLDBACH-MANSKY, R.; KASTNER, D. L. Autoinflammation: the prominent role of IL-1 in monogenic autoinflammatory diseases and implications for common illnesses. The Journal of Allergy and Clinical Immunology, v. 124, n. 6, p. 1141-9; quiz 1150, Dec. 2009.

GOLDSCHMIDT R., \& PASSOS E. Data. Mining: um guia prático. Editora Campus, Rio de. Janeiro: Elsevier, 2005.

HAGAN, T. et al. Systems vaccinology: Enabling rational vaccine design with systems biological approaches. Vaccine, v. 33, n. 40, p. 5294-5301, 29 Sep. 2015.

HAKS, M. C. et al. Focused human gene expression profiling using dual-color reverse transcriptase multiplex ligation-dependent probe amplification. Vaccine, v. 33, n. 40, p. 
5282-5288, 29 Sep. 2015.

HALPERIN, S. A. et al. Six-Month Safety Data of Recombinant Vesicular Stomatitis Virus-Zaire Ebola Virus Envelope Glycoprotein Vaccine in a Phase 3 Double-Blind, Placebo-Controlled Randomized Study in Healthy Adults. The Journal of Infectious Diseases, v. 215, n. 12, p. 1789-1798, 15 Jun. 2017.

HALPERIN, S. A. et al. Immunogenicity, Lot Consistency, and Extended Safety of rVSVIG-ZEBOV-GP Vaccine: A Phase 3 Randomized, Double-Blind, Placebo-Controlled Study in Healthy Adults. The Journal of Infectious Diseases, v. 220, n. 7, p. 1127-1135, 30 Aug. 2019.

HEATON, S. M.; BORG, N. A.; DIXIT, V. M. Ubiquitin in the activation and attenuation of innate antiviral immunity. The Journal of Experimental Medicine, v. 213, n. 1, p. 1-13, 11 Jan. 2016.

HENAO-RESTREPO, A. M. et al. Efficacy and effectiveness of an rVSV-vectored vaccine in preventing Ebola virus disease: final results from the Guinea ring vaccination, open-label, cluster-randomised trial (Ebola Ça Suffit!). The Lancet, v. 389, n. 10068, p. 505-518, 4 Feb. 2017.

HEPPNER, D. G. et al. Safety and immunogenicity of the rVSV $\Delta$ G-ZEBOV-GP Ebola virus vaccine candidate in healthy adults: a phase $1 \mathrm{~b}$ randomised, multicentre, double-blind, placebo-controlled, dose-response study. The Lancet Infectious Diseases, v. 17, n. 8, p. 854-866, 9 Jun. 2017.

HOENEN, T. et al. Ebola virus: unravelling pathogenesis to combat a deadly disease. Trends in Molecular Medicine, v. 12, n. 5, p. 206-215, May 2006.

HOQUE N., BHATTACHARYYA D. K., AND KALITA J. K., "MIFS-ND: A mutual information-based feature selection method", Expert Systems with Applications, vol. 41, issue 14, pp. 6371-6385, 2014.

HOTELLING $\mathrm{H}$. Analysis of a complex of statistical variables into principal components. J. Educ. Psychol. 24, 417-441, 498-520, 1933.

HOU, S.-M.; HOU, C.-H.; LIU, J.-F. CX3CL1 promotes MMP-3 production via the CX3CR1, c-Raf, MEK, ERK, and NF-KB signaling pathway in osteoarthritis synovial fibroblasts. Arthritis Research \& Therapy, v. 19, n. 1, p. 282, 21 Dec. 2017.

HOWLETT, P. J. et al. Case Series of Severe Neurologic Sequelae of Ebola Virus Disease during Epidemic, Sierra Leone. Emerging Infectious Diseases, v. 24, n. 8, p. 1412-1421, 2018.

HUANG, Y. et al. The assembly of Ebola virus nucleocapsid requires virion-associated proteins 35 and 24 and posttranslational modification of nucleoprotein. Molecular Cell, v. 10, n. 2, p. 307-316, Aug. 2002.

HUTTNER, A. et al. The effect of dose on the safety and immunogenicity of the VSV Ebola candidate vaccine: a randomised double-blind, placebo-controlled phase $1 / 2$ trial. The Lancet Infectious Diseases, v. 15, n. 10, p. 1156-1166, Oct. 2015.

HUTTNER, A. et al. A dose-dependent plasma signature of the safety and immunogenicity of the rVSV-Ebola vaccine in Europe and Africa. Science Translational Medicine, v. 9, n. 
385, 12 Apr. 2017.

ISHII, K. et al. Perforin-deficient CAR T cells recapitulate late-onset inflammatory toxicities observed in patients. The Journal of Clinical Investigation, 1 Oct. 2020.

JACOBS, M. et al. Late Ebola virus relapse causing meningoencephalitis: a case report. The Lancet, v. 388, n. 10043, p. 498-503, 30 Jul. 2016.

JADAV, S. S. et al. Ebola virus: current and future perspectives. Infectious Disorders Drug Targets, v. 15, n. 1, p. 20-31, 2015.

JOHNSON, R. F. et al. An Inactivated Rabies Virus-Based Ebola Vaccine, FILORAB1, Adjuvanted With Glucopyranosyl Lipid A in Stable Emulsion Confers Complete Protection in Nonhuman Primate Challenge Models. The Journal of Infectious Diseases, v. 214, n. suppl 3, p. S342-S354, 15 Oct. 2016.

JONES, S. M. et al. Live attenuated recombinant vaccine protects nonhuman primates against Ebola and Marburg viruses. Nature Medicine, v. 11, n. 7, p. 786-790, Jul. 2005.

JONES, S. M. et al. Assessment of a vesicular stomatitis virus-based vaccine by use of the mouse model of Ebola virus hemorrhagic fever. The Journal of Infectious Diseases, v. 196 Suppl 2, p. S404-12, 15 Nov. 2007.

JOOSTEN, S. A. et al. Identification of biomarkers for tuberculosis disease using a novel dual-color RT-MLPA assay. Genes and Immunity, v. 13, n. 1, p. 71-82, Jan. 2012.

KANAPATHIPILLAI, R. et al. Ebola vaccine--an urgent international priority. The New England Journal of Medicine, v. 371, n. 24, p. 2249-2251, 11 Dec. 2014.

KAPLAN J., SCHLEGEL B. fastDummies: Fast Creation of Dummy (Binary) Columns and Rows from Categorical Variables. $\mathbf{R}$ package version 1.3.0. https://cran.r-project.org/web/packages/fastDummies/index.html, 2019.

KHATRI, P.; SIROTA, M.; BUTTE, A. J. Ten years of pathway analysis: current approaches and outstanding challenges. PLoS Computational Biology, v. 8, n. 2, p. e1002375, 23 Feb. 2012.

KIRA, K., and RENDELLI, L. A. The feature selection problem: Traditional methods and a new algorithm. In Proceedings of the AAAI-92, AAAI Press, pp. 129-134, 1992.

KOHAVI, R.; JOHN, G. H. Wrappers for feature subset selection. Artificial intelligence, v. 97, n. 1-2, p. 273-324, Dec. 1997.

KUHN M. ET. AL. caret: Classification and Regression Training. $\mathbf{R}$ package version 6.0-71. https://CRAN.R-project.org/package=caret, 2016.

KURSA, M. B.; JANKOWSKI, A.; RUDNICKI, W. R. Boruta - A System for Feature Selection. Fundamenta Informaticae, 1 Jan. 2010.

LAI, C.-Y. et al. Ebola Virus Glycoprotein Induces an Innate Immune Response In vivo via TLR4. Frontiers in microbiology, v. 8, p. 1571, 17 Aug. 2017.

LARSON, H. J. et al. Measuring vaccine confidence: analysis of data obtained by a media surveillance system used to analyse public concerns about vaccines. The Lancet Infectious Diseases, v. 13, n. 7, p. 606-613, Jul. 2013. 
LARSON, H. J. et al. Understanding Vaccine Hesitancy Around Vaccines and Vaccination from a Global Perspective: a Systematic Review of Published Literature, 2007-2012. Vaccine, v. 32, n. 19, p. 2150-2159, 17 Apr. 2014.

LATKOWSKI, T.; OSOWSKI, S. Computerized system for recognition of autism on the basis of gene expression microarray data. Computers in biology and medicine, v. 56, p. 82-88, Jan. 2015.

LA DISTIA NORA, R. et al. Retinal Pigment Epithelial Cells Control Early Mycobacterium tuberculosis Infection via Interferon Signaling. Investigative Ophthalmology \& Visual Science, v. 59, n. 3, p. 1384-1395, 1 Mar. 2018.

LEDGERWOOD, J. E.; SULLIVAN, N. J.; GRAHAM, B. S. Chimpanzee Adenovirus Vector Ebola Vaccine--Preliminary Report. The New England Journal of Medicine, v. 373, n. 8, p. 776, 20 Aug. 2015.

LELIGDOWICZ, A. et al. Ebola virus disease and critical illness. Critical Care, v. 20, n. 1, p. 217, 29 Jul. 2016.

LÉVY, Y. et al. Prevention of Ebola virus disease through vaccination: where we are in 2018. The Lancet, v. 392, n. 10149, p. 787-790, 1 Sep. 2018.

LIAW A. and WIENER M. . Classification and Regression by randomForest. R News 2(3), 18--22, 2002.

LINGEMANN, M. et al. Attenuated human parainfluenza virus type 1 expressing ebola virus glycoprotein GP administered intranasally is immunogenic in african green monkeys. Journal of Virology, v. 91, n. 10, 15 May 2017.

LIU, X. et al. Transcriptomic signatures differentiate survival from fatal outcomes in humans infected with Ebola virus. Genome Biology, v. 18, n. 1, p. 4, 19 Jan. 2017.

$\mathrm{LI}, \mathrm{S}$. et al. Molecular signatures of antibody responses derived from a systems biology study of five human vaccines. Nature Immunology, v. 15, n. 2, p. 195-204, Feb. 2014.

LOVE, M. I.; HUBER, W.; ANDERS, S. Moderated estimation of fold change and dispersion for RNA-seq data with DESeq2. Genome Biology, v. 15, n. 12, p. 550, 2014.

MAGITTA, N. F. et al. A coding polymorphism in NALP1 confers risk for autoimmune Addison's disease and type 1 diabetes. Genes and Immunity, v. 10, n. 2, p. 120-124, Mar. 2009.

MALDONADO, S.; LÓPEZ, J. Dealing with high-dimensional class-imbalanced datasets: Embedded feature selection for SVM classification. Applied soft computing, v. 67, p. 94-105, Jun. 2018.

MALVY, D. et al. Ebola virus disease. The Lancet, v. 393, n. 10174, p. 936-948, 2 Mar. 2019.

MARTINS, K. A. et al. Ebola virus disease candidate vaccines under evaluation in clinical trials. Expert review of vaccines, v. 15, n. 9, p. 1101-1112, 27 May 2016.

MARTIN, B.; CANARD, B.; DECROLY, E. Filovirus proteins for antiviral drug discovery: Structure/function bases of the replication cycle. Antiviral Research, v. 141, p. 48-61, 10 Feb. 2017. 
MARZI, A. et al. Vaccines. An Ebola whole-virus vaccine is protective in nonhuman primates. Science, v. 348, n. 6233, p. 439-442, 24 Apr. 2015.

MARZI, A. et al. Single low-dose VSV-EBOV vaccination protects cynomolgus macaques from lethal Ebola challenge. EBioMedicine, v. 49, p. 223-231, Nov. 2019.

MEHEDI, M. et al. A new Ebola virus nonstructural glycoprotein expressed through RNA editing. Journal of Virology, v. 85, n. 11, p. 5406-5414, Jun. 2011.

MITRA, S.; CHENG, K. W.; MILLS, G. B. Rab GTPases implicated in inherited and acquired disorders. Seminars in Cell \& Developmental Biology, v. 22, n. 1, p. 57-68, Feb. 2011.

MONATH, T. P. et al. rVSVAG-ZEBOV-GP (also designated V920) recombinant vesicular stomatitis virus pseudotyped with Ebola Zaire Glycoprotein: Standardized template with key considerations for a risk/benefit assessment. Vaccine: X, v. 1, p. 100009, 11 Apr. 2019.

MOOKHERJEE N.; Innate defence regulatory peptide compositions for treatment of arthritis; University of Manitoba; CA2802912A1; 15/06/2010; Disponível em: https://patents.google.com/patent/CA2802912A1/en e Acesso em: 09/02/2021.

MURRAY, M. J. Ebola virus disease: A review of its past and present. Anesthesia and Analgesia, v. 121, n. 3, p. 798-809, Sep. 2015.

NAKAYA, $\mathrm{H}$. I. et al. Systems biology of vaccination for seasonal influenza in humans. Nature Immunology, v. 12, n. 8, p. 786-795, 10 Jul. 2011.

NAKAYA, H. I. et al. Systems Analysis of Immunity to Influenza Vaccination across Multiple Years and in Diverse Populations Reveals Shared Molecular Signatures. Immunity, v. 43, n. 6, p. 1186-1198, 15 Dec. 2015.

NAKAYA, H. I.; PULENDRAN, B. Vaccinology in the era of high-throughput biology. Philosophical Transactions of the Royal Society of London. Series B, Biological Sciences, v. 370, n. 1671, 19 Jun. 2015.

NANKI, T.; IMAI, T.; KAWAI, S. Fractalkine/CX3CL1 in rheumatoid arthritis. Modern Rheumatology, v. 27, n. 3, p. 392-397, May 2017.

NASCIMENTO, M. C. V.; TOLEDO, F. M. B.; DE CARVALHO, A. C. P. L. F. Investigation of a new GRASP-based clustering algorithm applied to biological data. Computers \& operations research, v. 37, n. 8, p. 1381-1388, Aug. 2010.

ODAI, T. et al. Correlation of CX3CL1 and CX3CR1 levels with response to infliximab therapy in patients with rheumatoid arthritis. The Journal of Rheumatology, v. 36, n. 6, p. 1158-1165, Jun. 2009.

OLIVEROS, J.C. VENNY. An interactive tool for comparing lists with Venn's diagrams. http://bioinfogp.cnb.csic.es/tools/venny/index.html, 2007-2015.

OMS. Major milestone for WHO-supported Ebola vaccine. 2019. Disponível em: who.int/news/item/18-10-2019-major-milestone-for-who-supported-ebola-vaccine. Acesso em: 23 de fev. 2021.

OMS. Ebola virus disease - Guinea. 2021. Disponível em: https://www.who.int/csr/don/17-february-2021-ebola-gin/en/. Acesso em 05 de mar. de 2021.

ORGAN, E. L. et al. Discovery of mammalian genes that participate in virus infection. BMC 
Cell Biology, v. 5, n. 1, p. 41, 2 Nov. 2004.

OWZAR, K. et al. Statistical challenges in preprocessing in microarray experiments in cancer. Clinical Cancer Research, v. 14, n. 19, p. 5959-5966, 1 Oct. 2008.

PEARL, J. Probabilistic Reasoning in Intelligent Systems: Networks of Plausible Inference. Morgan Kaufmann Publishers, San Francisco, 1988.

PEARSON K.. On lines and planes of closest fit to systems of points in space. Phil. Mag. 2, 559-572, 1901.

PLOTKIN, S. History of vaccination. Proceedings of the National Academy of Sciences of the United States of America, v. 111, n. 34, p. 12283-12287, 26 Aug. 2014.

POLAND, G. A. et al. Vaccinomics, adversomics, and the immune response network theory: individualized vaccinology in the 21 st century. Seminars in Immunology, v. 25, n. 2, p. 89-103, Apr. 2013.

POLLARD, A. J. et al. Safety and immunogenicity of a two-dose heterologous Ad26.ZEBOV and MVA-BN-Filo Ebola vaccine regimen in adults in Europe (EBOVAC2): a randomised, observer-blind, participant-blind, placebo-controlled, phase 2 trial. The Lancet Infectious Diseases, 17 Nov. 2020.

POLLARD, A. J.; BIJKER, E. M. A guide to vaccinology: from basic principles to new developments. Nature Reviews. Immunology, v. 21, n. 2, p. 83-100, 2020.

PONTILLO, A. et al. Polimorphisms in inflammasome genes are involved in the predisposition to systemic lupus erythematosus. Autoimmunity, v. 45, n. 4, p. 271-278, Jun. 2012a.

PONTILLO, A. et al. NALP1/NLRP1 genetic variants are associated with Alzheimer disease. Alzheimer Disease and Associated Disorders, v. 26, n. 3, p. 277-281, Sep. 2012b.

PREVOTS, D. R. et al. Interruption of measles transmission in Brazil, 2000-2001. The Journal of Infectious Diseases, v. 187 Suppl 1, p. S111-20, 15 May 2003.

QUEREC, T. D. et al. Systems biology approach predicts immunogenicity of the yellow fever vaccine in humans. Nature Immunology, v. 10, n. 1, p. 116-125, Jan. 2009.

QURESHI, A. I. et al. Study of ebola virus disease survivors in guinea. Clinical Infectious Diseases, v. 61, n. 7, p. 1035-1042, 1 Oct. 2015.

RAN, D.; DAYE, Z. J. Gene expression variability and the analysis of large-scale RNA-seq studies with the MDSeq. Nucleic Acids Research, v. 45, n. 13, p. e127, 27 Jul. 2017.

RECHTIEN, A. et al. Systems Vaccinology Identifies an Early Innate Immune Signature as a Correlate of Antibody Responses to the Ebola Vaccine rVSV-ZEBOV. Cell reports, v. 20, n. 9, p. 2251-2261, 29 Aug. 2017.

REGULES, J. A. et al. A recombinant vesicular stomatitis virus ebola vaccine. The New England Journal of Medicine, v. 376, n. 4, p. 330-341, 26 Jan. 2017.

RUSSO, P. S. T. et al. CEMiTool: a Bioconductor package for performing comprehensive modular co-expression analyses. BMC Bioinformatics, v. 19, n. 1, p. 56, 20 Feb. 2018.

SÁ, D. C. DE; FESTA, C. Inflammasomes and dermatology. Anais brasileiros de 
dermatologia, v. 91, n. 5, p. 566-578, Oct. 2016.

SANTORO, F. et al. Human Transcriptomic Response to the VSV-Vectored Ebola Vaccine. Vaccines, v. 9, n. 2, 20 Jan. 2021.

SERGUSHICHEV, A. An algorithm for fast preranked gene set enrichment analysis using cumulative statistic calculation. BioRxiv, 20 Jun. 2016.

SHANNON, P. et al. Cytoscape: a software environment for integrated models of biomolecular interaction networks. Genome Research, v. 13, n. 11, p. 2498-2504, Nov. 2003.

SISSOKO, D. et al. Ebola virus persistence in breast milk after no reported illness: A likely source of virus transmission from mother to child. Clinical Infectious Diseases, v. 64, n. 4, p. 513-516, 15 Feb. 2017.

SLOOT, R. et al. Biomarkers Can Identify Pulmonary Tuberculosis in HIV-infected Drug Users Months Prior to Clinical Diagnosis. EBioMedicine, v. 2, n. 2, p. 172-179, 2015.

SPEARMAN, P. Viral interactions with host cell Rab GTPases. Small GTPases, v. 9, n. 1-2, p. 192-201, 4 Mar. 2018.

SPERANZA, E.; CONNOR, J. H. Host transcriptional response to ebola virus infection. Vaccines, v. 5, n. 3, 20 Sep. 2017.

STANLEY, D. A. et al. Chimpanzee adenovirus vaccine generates acute and durable protective immunity against ebolavirus challenge. Nature Medicine, v. 20, n. 10, p. 1126-1129, Oct. 2014.

STROWIG, T. et al. Inflammasomes in health and disease. Nature, v. 481, n. 7381, p. 278-286, 18 Jan. 2012.

SUBRAMANIAN, A. et al. Gene set enrichment analysis: a knowledge-based approach for interpreting genome-wide expression profiles. Proceedings of the National Academy of Sciences of the United States of America, v. 102, n. 43, p. 15545-15550, 25 Oct. 2005.

SUDER, E. et al. The vesicular stomatitis virus-based Ebola virus vaccine: From concept to clinical trials. Human vaccines \& immunotherapeutics, v. 14, n. 9, p. 2107-2113, 18 Jun. 2018.

SULLIVAN, N. J. et al. Development of a preventive vaccine for Ebola virus infection in primates. Nature, v. 408, n. 6812, p. 605-609, 30 Nov. 2000.

SULLIVAN, N. J. et al. Immune protection of nonhuman primates against Ebola virus with single low-dose adenovirus vectors encoding modified GPs. PLoS Medicine, v. 3, n. 6, p. e177, Jun. 2006.

TAPIA, M. D. et al. Safety, reactogenicity, and immunogenicity of a chimpanzee adenovirus vectored Ebola vaccine in children in Africa: a randomised, observer-blind, placebo-controlled, phase 2 trial. The Lancet Infectious Diseases, v. 20, n. 6, p. 719-730, 19 Mar. 2020.

TARCA, A. L.; ROMERO, R.; DRAGHICl, S. Analysis of microarray experiments of gene expression profiling. American Journal of Obstetrics and Gynecology, v. 195, n. 2, p. 373-388, Aug. 2006. 
TAUB, M. A.; CORRADA BRAVO, H.; IRIZARRY, R. A. Overcoming bias and systematic errors in next generation sequencing data. Genome Medicine, v. 2, n. 12, p. 87, 10 Dec. 2010.

THANAPATI, S. et al. Impaired NK cell functionality and increased TNF- $\alpha$ production as biomarkers of chronic chikungunya arthritis and rheumatoid arthritis. Human Immunology, v. 78, n. 4, p. 370-374, Apr. 2017.

TIFFANY, A. et al. Ebola virus disease complications as experienced by survivors in sierra leone. Clinical Infectious Diseases, v. 62, n. 11, p. 1360-1366, 1 Jun. 2016.

VAPNIK, V. N. Statistical learning theory. New York, Wiley, 1998.

VARKEY, J. B. et al. Persistence of Ebola Virus in Ocular Fluid during Convalescence. The New England Journal of Medicine, v. 372, n. 25, p. 2423-2427, 18 Jun. 2015.

WARFIELD, K. L. et al. Ebola virus-like particle-based vaccine protects nonhuman primates against lethal Ebola virus challenge. The Journal of Infectious Diseases, v. 196 Suppl 2, p. S430-7, 15 Nov. 2007.

WICKHAM H, ET AL. . dplyr: A Grammar of Data Manipulation. R package version 0.7.6. https://CRAN.R-project.org/package=dplyr,2018.

WITTEN I. H. AND FRANK E. , Data mining: Practical machine learning tools and techniques, San Francisco CA, USA: Morgan Kaufmann, 2011.

WONG, G. et al. Immunization with vesicular stomatitis virus vaccine expressing the Ebola glycoprotein provides sustained long-term protection in rodents. Vaccine, v. 32, n. 43, p. 5722-5729, 29 Sep. 2014.

WORLD HEALTH ORGANIZATION. Ebola haemorrhagic fever in Zaire, 1976. Bulletin of the World Health Organization, v. 56, n. 2, p. 271-293, 1978.

YU L. \& LIU H., "Feature Selection for High-Dimensional Data: A Fast Correlation-Based Filter Solution," in: Proc. 20th International Conference on Machine Learning (ICML-2003), Washington DC, USA, AAAI Press, pp. 856-863, 2003.

XIA, J.; GILL, E. E.; HANCOCK, R. E. W. NetworkAnalyst for statistical, visual and network-based meta-analysis of gene expression data. Nature Protocols, v. 10, n. 6, p. 823-844, Jun. 2015.

ZHANG, B.; HORVATH, S. A general framework for weighted gene co-expression network analysis. Statistical Applications in Genetics and Molecular Biology, v. 4, p. Article17, 12 Aug. 2005. 


\section{Anexos}

A. Tabelas suplementares

Tabela Suplementar 1. Número absoluto de eventos adversos por coorte

\begin{tabular}{lcccccc}
\hline $\begin{array}{l}\text { Evento } \\
\text { Adverso }\end{array}$ & $\begin{array}{c}\text { EUA } \\
\text { vacinados } \\
\mathbf{( 4 1 8 )}\end{array}$ & $\begin{array}{c}\text { EUA } \\
\text { placebos } \\
\mathbf{( 9 8 )}\end{array}$ & $\begin{array}{c}\text { Genebra } \\
\text { vacinado } \\
\mathbf{s}(\mathbf{1 1 2})\end{array}$ & $\begin{array}{c}\text { Genebra } \\
\text { placebos } \\
\mathbf{( 1 3 )}\end{array}$ & $\begin{array}{c}\text { Gabão } \\
\text { vacinados } \\
\mathbf{( 1 1 5 )}\end{array}$ & $\begin{array}{c}\text { Kilifi } \\
\text { vacinados } \\
\mathbf{( 4 0 )}\end{array}$ \\
\hline EA local & 180 & 10 & 54 & 3 & 42 & 31 \\
Dor de cabeça & 153 & 26 & 48 & 4 & 53 & 21 \\
Fadiga & 122 & 18 & 65 & 4 & 43 & 25 \\
Mialgia & 108 & 11 & 56 & 3 & 19 & 10 \\
Febre & 77 & 3 & 47 & 2 & 25 & 11 \\
Calafrios & 81 & 7 & 42 & 2 & 4 & 8 \\
Artralgia & 68 & 8 & 16 & 1 & 25 & 0 \\
Náusea & 52 & 14 & 7 & 0 & 1 & 2 \\
Artrite & 19 & 1 & 24 & 0 & 0 & 1 \\
\hline
\end{tabular}

Entre parênteses apresenta-se o número total de voluntários em cada grupo.

Tabela Suplementar 2. Número relativo de eventos adversos por coorte

\begin{tabular}{lcccccc}
\hline Evento & $\begin{array}{c}\text { EUA } \\
\text { vacinados } \\
\mathbf{( 4 1 8 )}\end{array}$ & $\begin{array}{c}\text { EUA } \\
\text { placebos } \\
\mathbf{( 9 8 )}\end{array}$ & $\begin{array}{c}\text { Genebra } \\
\text { vacinados } \\
\mathbf{( 1 1 2 )}\end{array}$ & $\begin{array}{c}\text { Genebra } \\
\text { placebos } \\
\mathbf{( 1 3 )}\end{array}$ & $\begin{array}{c}\text { Gabão } \\
\text { vacinados } \\
\mathbf{( 1 1 5 )}\end{array}$ & $\begin{array}{c}\text { Kilifi } \\
\text { vacinados } \\
\mathbf{( 4 0 )}\end{array}$ \\
\hline EA local & 43,1 & 10,2 & 52,9 & 23 & 36,5 & 77,5 \\
Dor de cabeça & 36,6 & 26,5 & 47,1 & 30,8 & 46,1 & 52,5 \\
Fadiga & 29,2 & 18,4 & 63,7 & 30,8 & 37,4 & 62,5 \\
Mialgia & 25,8 & 11,2 & 54,9 & 23 & 16,5 & 25 \\
Febre & 18,4 & 3,1 & 46,1 & 15,4 & 21,7 & 27,5 \\
Calafrios & 19,4 & 7,1 & 41,2 & 15,4 & 3,5 & 20 \\
Artralgia & 16,3 & 8,2 & 15,7 & 7,7 & 21,7 & 0 \\
Náusea & 12,4 & 14,3 & 6,9 & 0 & 5 & 0,9 \\
Artrite & 19 & 1 & 23,5 & 0 & 0 & 2,5 \\
\hline
\end{tabular}

Entre parênteses apresenta-se o número total de voluntários em cada grupo. Números arredondados para 1 casa decimal depois da vírgula. 


\section{B. Ficha do Aluno}

Fanus - Sistema Administrativo da Pós-Graduaçăo

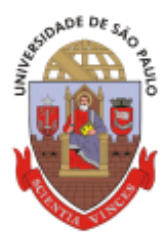

Universidade de São Paulo

Faculdade de Ciências Farmacêuticas

FICHA DO ALUNO

9136 - $10164169 / 2$ - Patrícia Conceição Gonzales Dias Carvalho

Email:

patricia.gonzalez@usp.br

Data de Nascimento:

19/10/1991

Cédula de Identidade:

RG - 47707.381-5 - SP

Local de Nascimento:

Estado de São Paulo

Nacionalidade:

Brasileira

Graduação:

Bacharela em Biotecnologia - Universidade Federal da Grande Dourados - Mato Grosso do Sul - Brasil - 2013

Mestrado:

Mestre em Ciências (1) - Fundação Oswaldo Cruz - São Paulo - Brasil - 2016

\section{Curso:}

Programa:

Área:

Data de Matrícula:

Início da Contagem de Prazo:

Data Limite para o Depósito:

Orientador:

Proficiência em Línguas:

Data de Aprovação no Exame de

Qualificaçăo:

Data do Depósito do Trabalho:

Título do Trabalho:

Data Máxima para Aprovação da

Banca:

Data de Aprovação da Banca:

Data Máxima para Defesa:

Data da Defesa:

Resultado da Defesa:

Histórico de Ocorrências:
Doutorado

Farmácia (Fisiopatologia e Toxicologia)

Análises Clínicas

02/05/2017

$02 / 05 / 2017$

03/05/2021

Prof(a). Dr(a). Helder Takashi Imoto Nakaya - 02/05/2017 até o presente. Email: hnakaya@gmail.com

Inglês, Aprovado em 02/05/2017

Aprovado em 18/06/2019

Primeira Matrícula em 02/05/2017

Aluno matriculado no Regimento da Pós-Graduação USP (Resolução nº 6542 em vigor de 20/04/2013 até 28/03/2018).

Última ocorrência: Matrícula de Acompanhamento em 27/07/2020

Impresso em: 10/03/2021 15:24:22 
Universidade de São Paulo

Faculdade de Ciências Farmacêuticas

FICHA DO ALUNO

9136 - 10164169/2 - Patrícia Conceição Gonzales Dias Carvalho

\begin{tabular}{|c|c|c|c|c|c|c|c|c|c|}
\hline Sigla & Nome da Disciplina & Início & Término & $\begin{array}{c}\text { Carga } \\
\text { Horária } \\
\end{array}$ & Cred. & Freq. & Conc. & Exc. & Situação \\
\hline $\begin{array}{c}\text { FBC5707- } \\
6 / 1\end{array}$ & Biologia de Sistemas para Ciências da Vida (2) & $26 / 10 / 2016$ & $08 / 12 / 2016$ & 60 & 4 & 100 & A & $\mathrm{N}$ & Concluída \\
\hline $\begin{array}{c}\text { FBC5780- } \\
2 / 4\end{array}$ & Análise de Dados Aplicados às Pesquisas Biológicas & 07/08/2017 & $17 / 09 / 2017$ & 90 & 6 & 90 & A & $\mathrm{N}$ & Concluída \\
\hline $\begin{array}{c}\text { FBC5766- } \\
6 / 1\end{array}$ & Tópicos em Fisiopatologia e Toxicologia IV & $15 / 08 / 2017$ & $27 / 11 / 2017$ & 15 & 1 & 85 & A & $\mathrm{N}$ & Concluída \\
\hline $\begin{array}{l}\text { FBA5728- } \\
\quad 4 / 5\end{array}$ & Aprimoramento Pedagógico & $12 / 09 / 2017$ & $10 / 10 / 2017$ & 60 & 4 & 75 & A & $\mathrm{N}$ & Concluída \\
\hline $\begin{array}{l}\text { FBC5710- } \\
7 / 1\end{array}$ & Vacinas e Adjuvantes & $13 / 11 / 2017$ & $17 / 12 / 2017$ & 60 & 0 & - & - & $\mathrm{N}$ & $\begin{array}{l}\text { Matrícula } \\
\text { cancelada }\end{array}$ \\
\hline $\begin{array}{l}\text { Atividade } \\
\quad \text { do } \\
\text { Programa }\end{array}$ & $\begin{array}{l}\text { Participou da Etapa de Estágio Supervisionado em } \\
\text { Docência do Programa de Aperfeiçoamento de Ensino } \\
\text { (PAE) junto à Disciplina FBC0519 "Imunodiagnóstico", } \\
\text { com carga horária total de } 120 \text { horas, sob supervisão do } \\
\text { Prof. Joilson de Oliviera Martins, ministrada aos alunos } \\
\text { de graduaçãa do curso de Farmácia e Bioquímica da } \\
\text { FCF/USP. (3) }\end{array}$ & $01 / 02 / 2018$ & $30 / 06 / 2018$ & - & 3 & - & - & - & - \\
\hline $\begin{array}{l}\text { FBC5792- } \\
5 / 1\end{array}$ & Tópicos em Fisiopatologia e Toxicologia III & 05/03/2018 & $19 / 06 / 2018$ & 15 & 1 & 88 & A & $\mathrm{N}$ & Concluída \\
\hline $\begin{array}{l}\text { IBI5031- } \\
4 / 4\end{array}$ & $\begin{array}{l}\text { Reconhecimento de Padrões I (Curso Interunidades: } \\
\text { Bioinformática - Universidade de São Paulo) }\end{array}$ & 05/03/2018 & $22 / 06 / 2018$ & 120 & 0 & - & - & $\mathrm{N}$ & $\begin{array}{l}\text { Pré- } \\
\text { matrícula } \\
\text { recusada }\end{array}$ \\
\hline $\begin{array}{l}\text { MCM5920- } \\
2 / 2\end{array}$ & $\begin{array}{l}\text { Desenvolvimento de Vacinas em Doenças Infecciosas } \\
\text { (Faculdade de Medicina - Universidade de São Paulo) }\end{array}$ & $18 / 06 / 2018$ & $24 / 06 / 2018$ & 30 & 2 & 100 & A & $\mathrm{N}$ & Concluída \\
\hline $\begin{array}{l}\text { ICB5752- } \\
1 / 4\end{array}$ & $\begin{array}{l}\text { Como Comunicar Sua Ciência: Melhorando a Oratória e a } \\
\text { Empatia com o Público (Instituto de Ciências Biomédicas } \\
\text { - Universidade de São Paulo) }\end{array}$ & $25 / 06 / 2018$ & $08 / 07 / 2018$ & 30 & 0 & - & - & $\mathrm{N}$ & $\begin{array}{l}\text { Pré- } \\
\text { matrícula } \\
\text { indeferida }\end{array}$ \\
\hline $\begin{array}{l}\text { FBC5710- } \\
\quad 8 / 1\end{array}$ & Vacinas e Adjuvantes & $19 / 11 / 2018$ & $09 / 12 / 2018$ & 90 & 6 & 100 & A & $\mathrm{N}$ & Concluída \\
\hline $\begin{array}{l}\text { FBC5959- } \\
\quad 1 / 1\end{array}$ & $\begin{array}{l}\text { Desenvolvendo sua comunicação científica no mundo } \\
\text { acadêmico }\end{array}$ & $19 / 03 / 2020$ & $29 / 04 / 2020$ & 90 & 6 & 100 & A & $\mathrm{N}$ & Concluída \\
\hline
\end{tabular}

\begin{tabular}{|c|c|c|c|}
\hline & \multicolumn{2}{|c|}{ Créditos mínimos exigidos } & \multirow[t]{2}{*}{ Créditos obtidos } \\
\hline & Para exame de qualificação & Para depósito de tese & \\
\hline Disciplinas: & 0 & 20 & 33 \\
\hline \multicolumn{4}{|l|}{ Estágios: } \\
\hline Total: & 0 & 20 & 33 \\
\hline
\end{tabular}

Créditos Atribuídos à Tese: 167 


\section{Currículo Lattes}

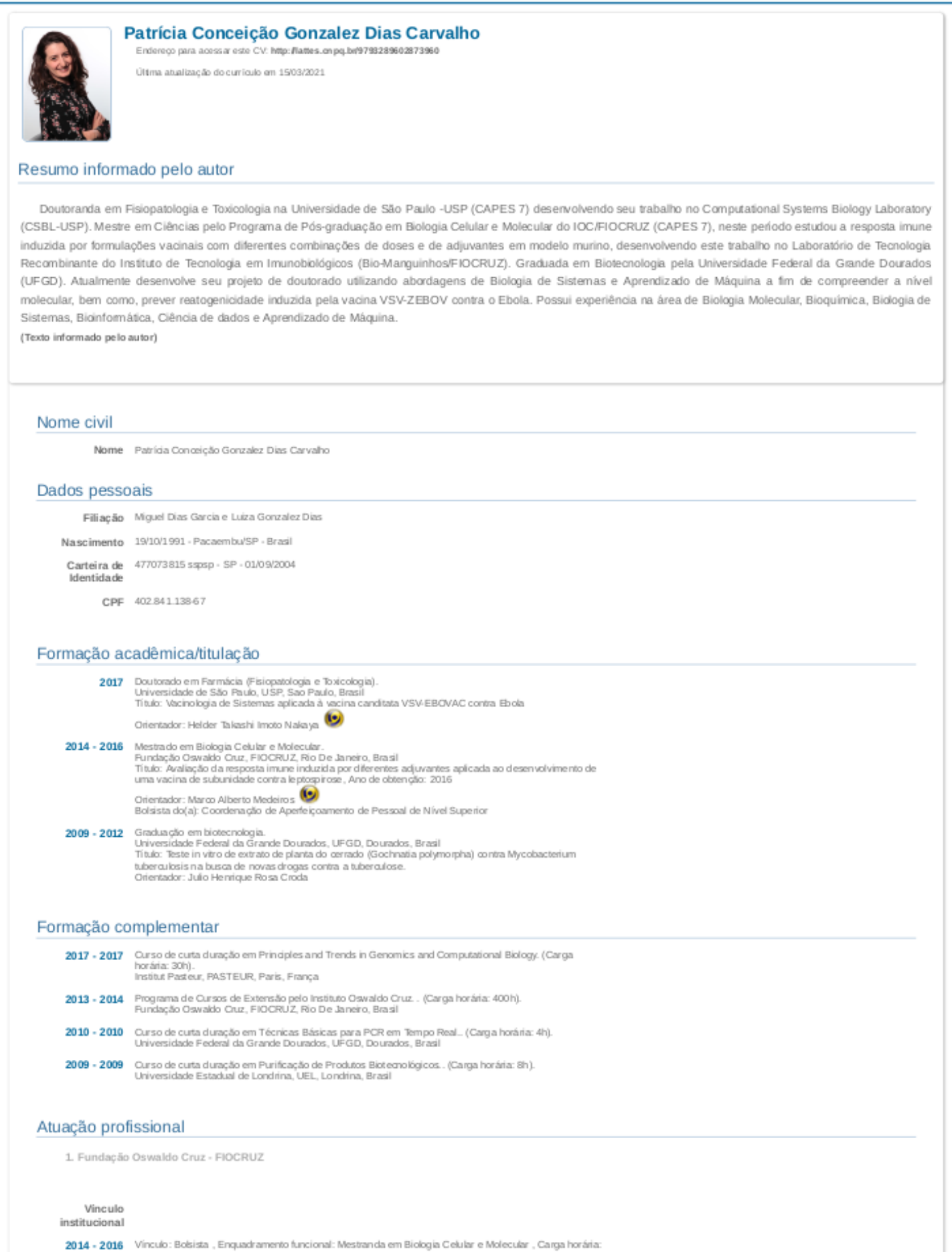


40, Regime: Dedcapto exdusiva

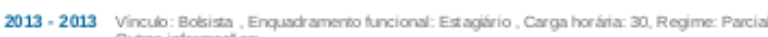

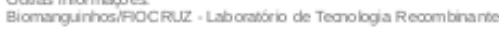

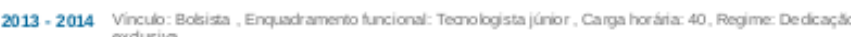

Afividades

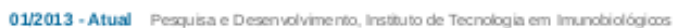

Linhas de pesquisa

Eatocnologia de Vaxinas

2. Universidade Federal do Fio de Janeiro - UFR.

\section{Vinculo}

$2014 \cdot 2014$

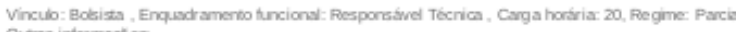

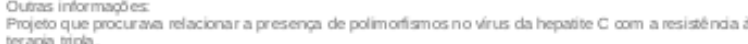

3. Universidade Federal da Gr ande Dourados - UFGD

Vinculo
institucional

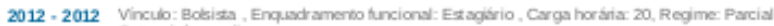

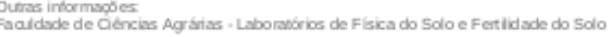

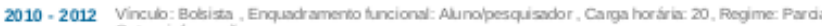
Outras intormsobses

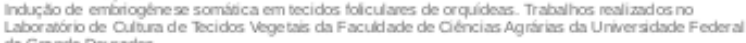
da Grande Douradoes

4. Sclavo Vaccines Association - VSVEBOPLUS

Vinculo
institucional

2017 - Atual

Linhas de pesquisa

1. Bicteconobgia de Vecinas

Prêmios e títulos

2016 Prémio Evandro Chaggas - Jovem Tierno, Bio-Manguirhos - Flocruz

Producão

Proctuçăa bibliográfic a

Artigos completos publicados em perídicicos

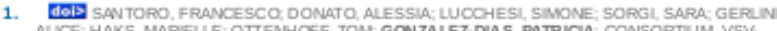

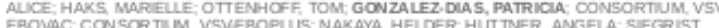
CAMRE, ANNE; MEDAGLINI, DONATA: POZZI, GINNNI H.uman Tranariptomic Response bo the VSVV Vectored Ebola Voccine. Vacanes. Echa v.9. p.67 - , 2021

2. WOA TEN CATEN, FEUPE; GONZALEZ DLAS, PATRICAA; CASTRO, IC ARO; OGAMA, RODRIGOL T:

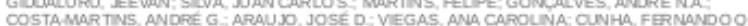

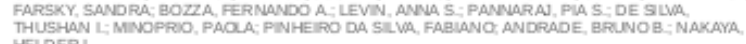

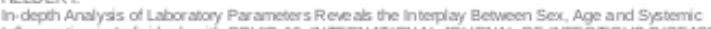

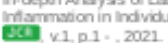

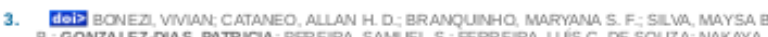

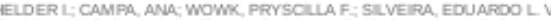

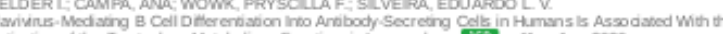

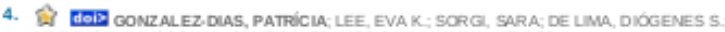

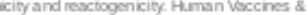
Immunotherapeuses. ECA $v .1, p .1$. 8, 2019

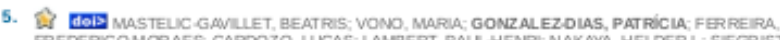
DLARE.ANNE 
6. Â TED SOARES SOHANOSKI, ALESSANDRA; BAPTISTA CRUZ, NATALLA: DE CASTRO JORGE

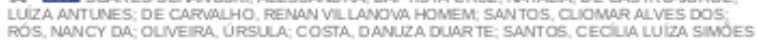

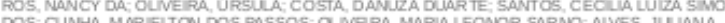

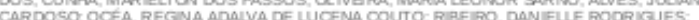

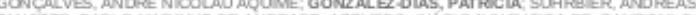
ZANOTTO, PAOLO MARINHO DE ANDRADE; AZEVEDO, NACOOJUNQUERTA DE; ZAMEON, DARIO S. ALMEDADA ROCUEA

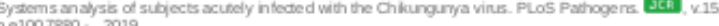
p.1007890 -2019

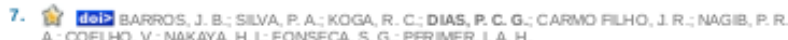

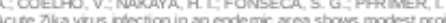

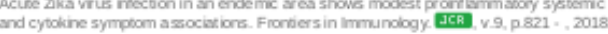

Trabalhos publicados em anais de eventos (resumo)

1. DCAS, P.C. G.;NAKAYA, H.

Ebola vascine induced athints: Gene predidors trom a Random Forez Model in: IN Internstions

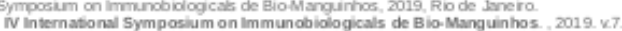

2. DuAS, P. C. G; - Moderos, M. A.

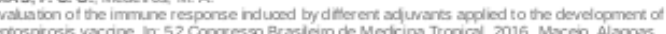

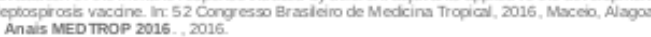

3. DeAs, P. C. G.; Mederos, M. A.

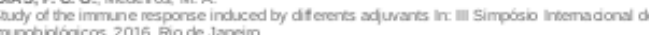
In: Simposio internacional de limunabiolo gicos. , 2016

4. ROSA, Y B.C. 1- SIIMA, S. R-MACEDO, M. C; HOFPMANN N. T.K-ANDRADE, A. O-DLAS, P. C. G ANALLACAOO DO EFEITODA ADICAOO DIFERENTES CONCENTRAOOOES DE POLEM APIOOLA EM Horiculara e Plarkas Ornamertas \& V Cong esso Brasilero de Culura de Tecidos de Plantas 2011

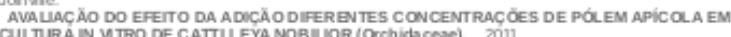

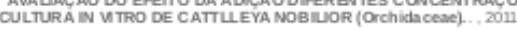

5. DLAS, P. C. G.; MACEDO, M. C.ROSA, Y. B. C. J; HOFFMANN, N. T. K. SIIVA, S. R; ANDRADE, A. O

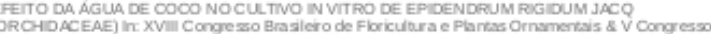
Grailero de Gitura de tecidios de Plantas, 2011 Jairalle. EFETO DA AGUA DE

6. SILVA, S. R; ROSA, Y. B C. J-MACEDO, M. C; HOFPMANN, N. T.K. A ANDRADE, A. O; DLAS, P. C.

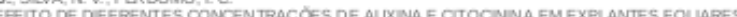

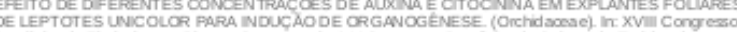

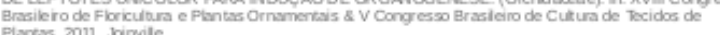
EFGTO DE DEFERENTES CONCENTRACÓES DE AUXINA E CTTOCNINA EM EXPLANTES POLIARES DE LEPTOTES UNICOL OR PARA NDUCC ÂO DE ORG ANOGÉNESE. (OrChidac EMe). 2011

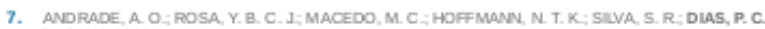

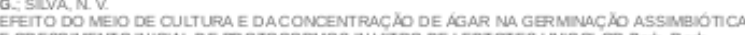
ECRESCIMENTO NICLAL DE FROTOCOFMOS IN VITRO DE LEPTOTIES UNICC OR Barh. ROA

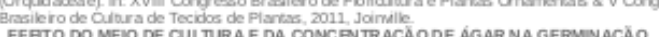

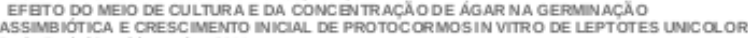
ASSIMBIOTICA E CRESCIMENTO

8. ANDRADE, A. O ; ROSA, Y. B. C. L; MACEDO, M. C; HOFFMANN N. T.K; SIIVA, S. R; DIAS, P. C. EFEITO DO MESO DE CULTURA E DACONCENTRACCAO DE AGAR NO CRESCIMENTO IN VITRO DE

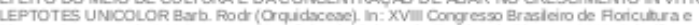

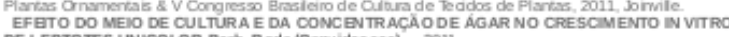

9. MACEDO, M. C; ROSA, Y. B. C. 1; M SUZZURI, R; HOFFMANN, N. I K; SUVA S R; ANDRRDE, A

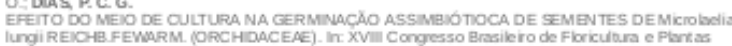

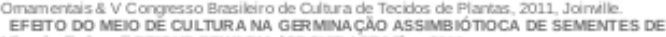

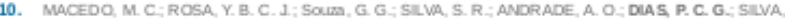
EVEITO DO NUMERO DE FRUTOS DA VIABLDADE DE SEMENTES DE DEndobium Nobile in: XVIII FFGTO DO NUMERO DE FRUTOS DA VIABLIDADE DE SEMENTES DE Dendrabium Noble., 2011.

11. DLAS, P. C. G.; ROSA, Y.B. C. J-MACEDO, M. C. HOFFMAN, N. T. K. SUVA, S. R- ANDRADE, A. O

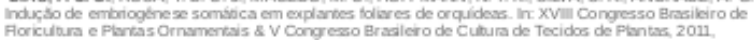
XViw Congresso Brasileiro de Flowic
Cultura de pe cidos de Pantas. 2011

12. SILVA, S. R: ROSA, Y. B C. J; MACEDO, M. C; HOFPMANN, N. T. K. ANDRADE, A. O; DIAS, P. C.

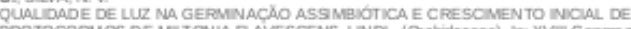

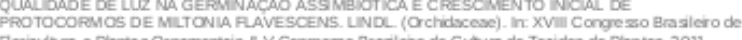

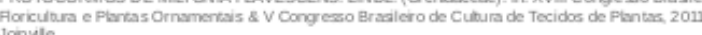
QUAL IDADE DE LUZ NA GERMINAC ÃO ASSIMBBÓTICA E CRESCMMENTO INICLAL DE PROTOCORM OS DE MLITONIA R.ANESCENS. LNDL. (Orchidacese)- , 2011

Trabalhos publicados em anais de eventos (resumo expandido)

1. MACEDO, M. C; ROSA, Y. B. C. 1; M SUZUKL, R; HOFFMANN, N. T K ; SIVVA N. V; ANDRADE A

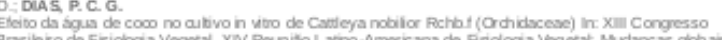

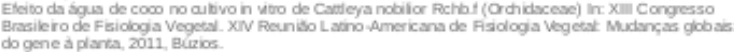




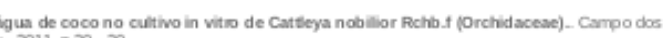

Página gerada pelo sistema Curriculo Lattes em 15/03/2021 as 17:32:10. 